Journal of

Medicinal Chemistry

Subscriber access provided by the Library (University of Lincoln)

Article

\title{
Design and synthesis of soluble and cell-permeable PI3K\# inhibitors for long-acting inhaled administration
}

Matthew W. D. Perry, Karin Björhall, Britta K. Bonn, Johan Carlsson, Yunhua Chen, Anders

Eriksson, Linda Fredlund, Hai'e Hao, Neil S. Holden, Kostas Karabelas, Helena Lindmark, Feifei Liu, Nils Pemberton, Jens Petersen, Sandra Rodrigo Blomqvist, Reed W. Smith, Tor Svensson, Ina Terstiege, Christian Tyrchan, Wenzhen Yang, Shuchun Zhao, and Linda Öster

J. Med. Chem., Just Accepted Manuscript • Publication Date (Web): 18 May 2017

Downloaded from http://pubs.acs.org on May 24, 2017

\section{Just Accepted}

"Just Accepted" manuscripts have been peer-reviewed and accepted for publication. They are posted online prior to technical editing, formatting for publication and author proofing. The American Chemical Society provides "Just Accepted" as a free service to the research community to expedite the dissemination of scientific material as soon as possible after acceptance. "Just Accepted" manuscripts appear in full in PDF format accompanied by an HTML abstract. "Just Accepted" manuscripts have been fully peer reviewed, but should not be considered the official version of record. They are accessible to all readers and citable by the Digital Object Identifier (DOI®). "Just Accepted" is an optional service offered to authors. Therefore, the "Just Accepted" Web site may not include all articles that will be published in the journal. After a manuscript is technically edited and formatted, it will be removed from the "Just Accepted" Web site and published as an ASAP article. Note that technical editing may introduce minor changes to the manuscript text and/or graphics which could affect content, and all legal disclaimers and ethical guidelines that apply to the journal pertain. ACS cannot be held responsible for errors or consequences arising from the use of information contained in these "Just Accepted" manuscripts. 
Medicines and Early Development, AstraZeneca Gothenburg, Medicinal Chemistry

Tyrchan, Christian; Respiratory, Inflammation and Autoimmunity, Innovative Medicines and Early Development, AstraZeneca Gothenburg, Medicinal Chemistry

Yang, Wenzhen; Pharmaron Beijing Co., Ltd.

Zhao, Shuchun; Pharmaron Beijing Co., Ltd.

Öster, Linda; Discovery Sciences, Innovative Medicines and Early

Development, AstraZeneca Gothenburg

\section{SCHOLARONE ${ }^{\text {in }}$}

Manuscripts 


\title{
Design and synthesis of soluble and cell-permeable
}

\section{PI3K $\delta$ inhibitors for long-acting inhaled}

\section{administration}

Authors Matthew W D Perry, ${ }^{* a b}$ Karin Björhall, ${ }^{a d}$ Britta Bonn, ${ }^{a c}$ Johan Carlsson, ${ }^{e}$ Yunhua Chen,,$^{f}$ Anders Eriksson, ${ }^{a b}$ Linda Fredlund, ${ }^{e}$ Hai'e Hao, ${ }^{f}$ Neil S Holden, ${ }^{a d}$ Kostas Karabelas, ${ }^{a}$ Helena Lindmark, ${ }^{e}$ Feifei Liu, ${ }^{f}$ Nils Pemberton, ${ }^{a b}$ Jens Petersen, ${ }^{e}$ Sandra Rodrigo Blomqvist, ${ }^{a d}$ Reed W Smith, ${ }^{a b}$ Tor Svensson, ${ }^{a b}$ Ina Terstiege, ${ }^{a b}$ Christian Tyrchan, ${ }^{a b}$ Wenzhen Yang, ${ }^{f}$ Shuchun Zhao, ${ }^{f}$ Linda Öster. ${ }^{e}$

${ }^{\text {a }}$ Respiratory, Inflammation and Autoimmunity, Innovative Medicines and Early Development, AstraZeneca Gothenburg, Pepparedsleden 1, SE-431 83 Mölndal, Sweden, ${ }^{\text {b }}$ Medicinal Chemistry, ${ }^{\mathrm{c}}$ DMPK, ${ }^{\mathrm{d}}$ BioScience, and ${ }^{\mathrm{e}}$ Discovery Sciences, Innovative Medicines and Early Development, AstraZeneca Gothenburg, Pepparedsleden 1, SE-431 83 Mölndal, Sweden, ${ }^{f}$ Pharmaron Beijing Co., Ltd., No.6 Taihe Road, BDA, Beijing, 100176, P.R. China

\begin{abstract}
PI3K $\delta$ is a lipid kinase that is believed to be important in the migration and activation of cells of the immune system. Inhibition is hypothesised to provide a powerful yet selective immunomodulatory effect that may be beneficial for the treatment of conditions such as asthma or rheumatoid arthritis. In this work we describe the identification of inhibitors based on a thiazolopyridone core structure and their subsequent optimisation for inhalation. The initially identified compound (13) had good potency and isoform selectivity
\end{abstract}


but was not suitable for inhalation. Addition of basic substituents to a region of the molecule pointing to solvent was tolerated (enzyme inhibition $\mathrm{pIC}_{50}>9$ ) and by careful manipulation of the pKa and lipophilicity we were able to discover compounds (20b, 20f) with good lung retention and cell potency that could be taken forward to in-vivo studies where significant target engagement could be demonstrated.

\section{Introduction}

Phosphoinositide 3-kinases (PI3Ks) are a group of enzymes that are involved in the phosphorylation of the membrane-bound inositol phospholipids in the 3-position of the inositol moiety. The eight known members are divided into three classes, I, II and III. Class I PI3Ks have been the most extensively studied of these subclasses; the class is further subdivided into IA (PI3K $\alpha, \beta \& \delta)$ and class IB (PI3K $\gamma$ ) based upon the types of regulatory subunits with which the catalytic domains combine in the active heterodimeric forms. Class 1A PI3Ks mediate the signal transduction from receptor tyrosine kinases whilst $\mathrm{PI} 3 \mathrm{~K} \gamma$ is principally activated by GPCRs. PI3K $\delta \& \gamma$ are restricted to cells of the haematopoietic system whilst PI3K $\alpha \& \beta$ are ubiquitous. Dysregulation of the PI3K system (the kinases and the associated phosphatases) is often observed in cancers and there has been a great deal of interest in developing pan or selective inhibitors of PI3Ks for applications in oncology. ${ }^{1,2}$ Evidence is growing that inhibition of PI3K $\delta$ and/or $\gamma$ can have powerful yet selective effects on the immune response and inhibitors have attracted interest as potential treatments for diseases with a significant immunological component, such as rheumatoid arthritis and asthma. $^{3-6}$ Understanding of the biology of PI3Ks is developing fast, however there are still details and subtleties to be worked out. Several reviews describe the current state of knowledge. ${ }^{7-10 \text {, }}$ 
Recently the PI3K $\delta$ selective inhibitor idelalisib (Figure 1, A) has been launched as the first PI3K inhibitor to market for the treatment of B-cell cancers. ${ }^{11}$ The drug is effective but shows a number of significant side-effects. ${ }^{12}$<smiles>CCC(Nc1ncnc2[nH]cnc12)c1nc2cccc(F)c2c(=O)n1-c1ccccc1</smiles>

A<smiles>Cc1ccccc1-n1c(Cn2cnc3c(N)ncnc32)nc2cccc(C)c2c1=O</smiles>

B

Figure 1. Reference PI $3 K \delta$ inhibitors.

We were interested in $\mathrm{PI} 3 \mathrm{~K} \delta$ as a potential treatment for lung conditions such as asthma. We have previously described an earlier series of PI3K $\delta$ inhibitors that we investigated but which showed disappointing cell potencies. ${ }^{13}$ We selected an inhaled approach with a view to minimising the systemic exposure and thus the potential for side-effects from either targetrelated or off-target interactions. This early decision to follow an inhaled approach mandated several aspects of our medicinal chemistry strategy: i, The limitations on dose deliverable through standard inhalers meant that achieving sub-nanomolar potency was crucial. ii, Soluble compounds are typically cleared from the lungs in a matter of minutes ${ }^{14}$ whilst inflammatory cells are recruited to the lung continuously, so sufficient exposure and retention in the lung is required. iii, In order to minimise systemic exposure oral bioavailability should be low and plasma clearance high.

Multiple chemotypes have been described as PI3K $\delta$ selective inhibitors. ${ }^{15}$ Broadly speaking they fall into two categories, "propeller" shaped compounds, such as idelalisib, that access an induced pocket ${ }^{16}$ and other chemotypes that all appear to derive selectivity by a 
combination of optimising the interactions in the affinity pocket for PI3K $\delta$ and accessing the "tryptophan shelf". The "tryptophan shelf" describes the face of Tyr760 (PI3K $\delta$ numbering) which is accessible in PI3K $\delta$ owing to the small size of Thr750, whereas larger residues in the corresponding positions of PI3K $\alpha, \beta$ and $\gamma$ occlude this surface. ${ }^{17}$

Since the disclosure of the structure of IC $87114^{18}$ (Figure 1, B) in 2003 there has been extensive medicinal chemistry exploration of chemotypes that can give "propeller" type structures. ${ }^{15}$ We started our search for PI3K $\delta$ inhibitors by looking for a novel propellershaped chemotype in view of the heavy patenting around 6,6-fused systems such as isoquinolinones and quinazolinones. We identified the thiazolopyridone ring system as a potentially suitable core for our explorations. Since the completion of the work described herein but prior to the submission of this article the same core has been described in the patent literature for some PI3K $\delta$ inhibitors. ${ }^{19}$

\section{Chemistry}

Synthesis of the compounds described in this paper followed a general route with late-stage diversification in order to introduce changes to the aryl substituents. The route (Scheme 1) started by following the procedures described by the Almqvist group for the synthesis of 6bromothiazolidinopyridones. ${ }^{20,21}$ Initially we used a racemic synthesis with late-stage chiral separation but the majority of work was carried out starting with chiral (R)-2-chloropropionic acid. Coupling of this acid with Meldrum's acid gave dioxinone 3. This dioxinone reacted thermally with thiazoline $\mathbf{2}$ to give the core ring system $\mathbf{4}$ as a mixture of diastereomers. Ring bromination of $\mathbf{4}$ was followed by sulfoxidation, Pummerer rearrangement and elimination to deliver the aromatised compound 7. Displacement of the chlorine with sodium azide followed by reduction gave amine 9. $\mathrm{CBZ}$ protection of the free amine produced carbamate 10. 
Suzuki coupling of racemic $\mathbf{1 0}$ from the initial synthesis with phenyl boronic acid gave $\mathbf{1 1}$ that was deprotected to amine 12 which on heating with 4-amino-6-chloropyrimidine-5carbonitrile, followed by separation of the enantiomers by chiral HPLC produced initial lead 13 (Scheme 2).

Chiral analysis of $\mathbf{1 0}$ produced using (R)-2-chloropropionic acid showed that some loss of stereochemical purity had occurred during the synthesis. $\mathbf{1 0}$ however proved to be suitable for chiral SFC and could be purified to $>99 \%$ enantiopurity. Cleavage of the carbamate returned chirally pure amine 9 that was used as the starting point for subsequent exploration (Scheme 3). Heating amine 9 and 4-amino-6-chloropyrimidine-5-carbonitrile in n-butanol gave the bromide 14 that was coupled with substituted phenyl boronic acids to give, after deprotections and, where required, reductive amination, compounds 15a and 17-19. Alternatively use of an aldehyde functionalised boronic acid gave intermediate $\mathbf{1 6}$ that could be reductively aminated with a range of amines to give, in some cases after additional manipulation, compounds $\mathbf{1 5 b} \mathbf{b} \mathbf{g}$ and 20a-l.
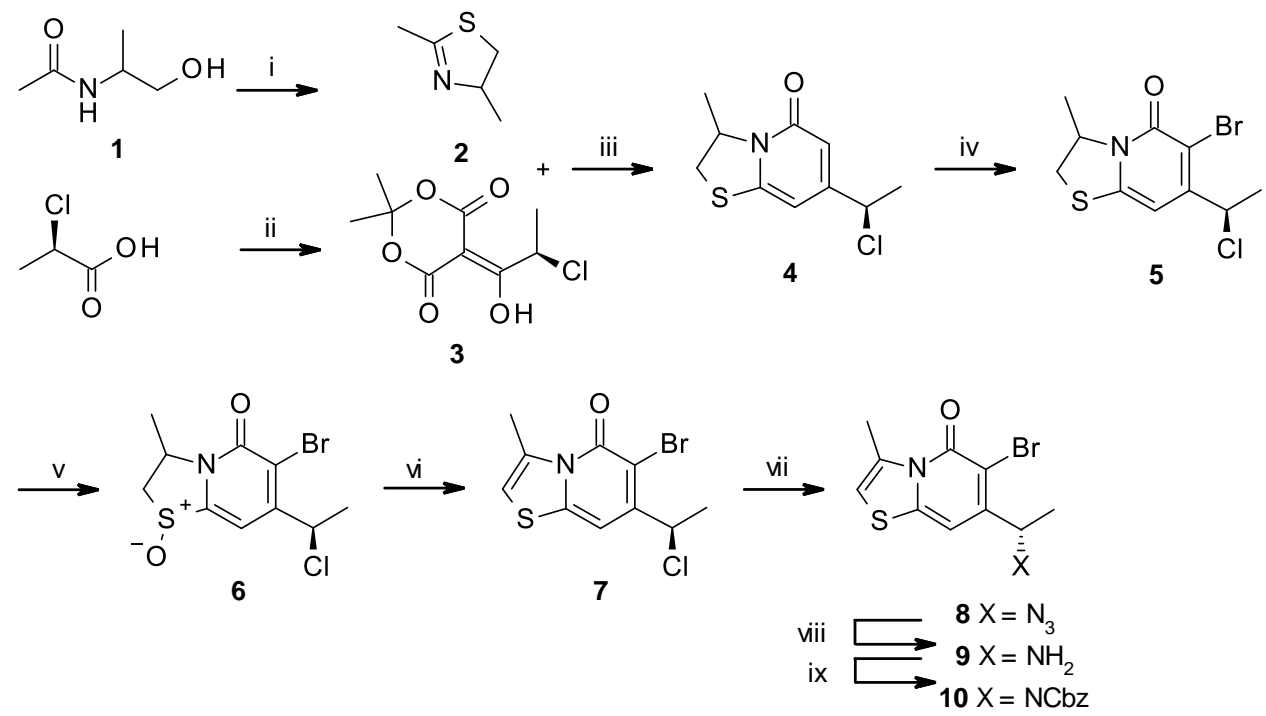

\section{Scheme 1.}


i, Lawesson's reagent, THF, $65^{\circ} \mathrm{C}$ ii, Meldrum's acid, DCC, DMAP, $\mathrm{CH}_{2} \mathrm{Cl}_{2}$ iii, TFA, TFAA, $\mathrm{ClCH}_{2} \mathrm{CH}_{2} \mathrm{Cl}$ iv, isoamyl nitrite, $\mathrm{HBr}\left(40 \%\right.$ aq) $, \mathrm{CH}_{2} \mathrm{Cl}_{2},<-5{ }^{\circ} \mathrm{C} \quad \mathrm{v}, \mathrm{mCPBA}$, $\mathrm{CH}_{2} \mathrm{Cl}_{2}, 0{ }^{\circ} \mathrm{C}$ vi, TFAA, PhMe, $60{ }^{\circ} \mathrm{C}$ then $\mathrm{cH}_{2} \mathrm{SO}_{4}, \mathrm{CH}_{2} \mathrm{Cl}_{2}, 0{ }^{\circ} \mathrm{C}-\mathrm{RT}$ vii, $\mathrm{NaN}_{3}, \mathrm{DMF}$, $45^{\circ} \mathrm{C}$ viii, $\mathrm{Ph}_{3} \mathrm{P}, \mathrm{CH}_{2} \mathrm{Cl}_{2}$, reflux ix, $\mathrm{CbzCl}, \mathrm{K}_{2} \mathrm{CO}_{3}$, THF: water $10: 1,0{ }^{\circ} \mathrm{C}$

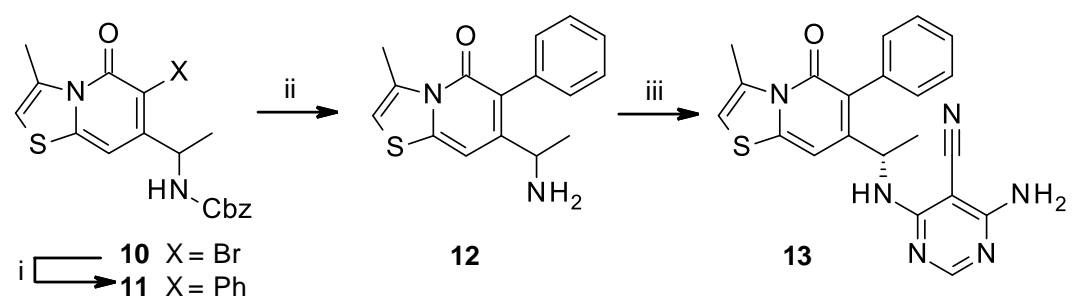

Scheme 2.

i $\mathrm{PhB}(\mathrm{OH})_{2}, \mathrm{PdCl}_{2}$ (dppf). $\mathrm{CH}_{2} \mathrm{Cl}_{2}$, DME-water, $100{ }^{\circ} \mathrm{C}$ ii, $\mathrm{BBr}_{3}, \mathrm{CH}_{2} \mathrm{Cl}_{2}, 0{ }^{\circ} \mathrm{C}-\mathrm{RT}$ iii, 4amino-6-chloropyrimidine-5-carbonitrile, DIEA, n-butanol, $120^{\circ} \mathrm{C}$ then Chiral HPLC

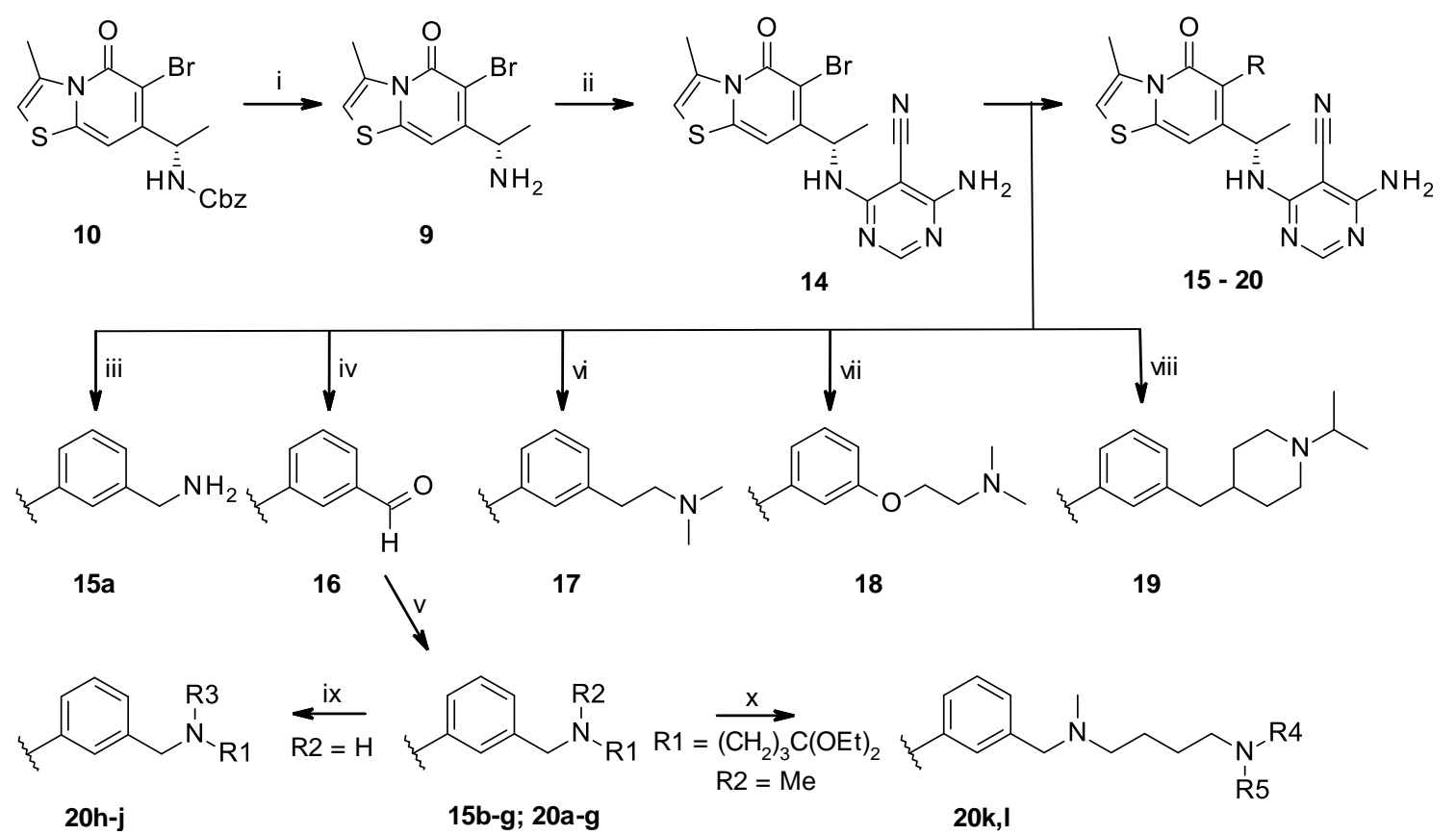

Scheme 3.

i, $\mathrm{BBr}_{3}, \mathrm{CH}_{2} \mathrm{Cl}_{2}, 0{ }^{\circ} \mathrm{C}-\mathrm{RT}$ ii, 4-amino-6-chloropyrimidine-5-carbonitrile , DIEA, nbutanol, $120^{\circ} \mathrm{C}$ iii, $\mathrm{ArB}(\mathrm{OH})_{2}, \mathrm{PdCl}_{2}(\mathrm{dppf}) \cdot \mathrm{CH}_{2} \mathrm{Cl}_{2}, \mathrm{Cs}_{2} \mathrm{CO}_{3}$, DME-water, $100^{\circ} \mathrm{C}$ then TFA, $\mathrm{CH}_{2} \mathrm{Cl}_{2}$ iv, $\mathrm{ArB}(\mathrm{OH})_{2} \mathrm{PdCl}_{2}$ (dppf). $\mathrm{CH}_{2} \mathrm{Cl}_{2}, \mathrm{Cs}_{2} \mathrm{CO}_{3}$, DME-water, $100{ }^{\circ} \mathrm{C}$ v HNRR, $\mathrm{NaBH}_{3} \mathrm{CN}, \mathrm{MeOH}-\mathrm{CH}_{2} \mathrm{Cl}_{2}$ vi, a) ArB(pinacol), $3^{\text {rd }}$ generation Pd precatalyst, $\mathrm{P}(\mathrm{Cy})_{3} \cdot \mathrm{HBF}_{4}$, $\mathrm{K}_{3} \mathrm{PO}_{4}$, dioxan-water, $130{ }^{\circ} \mathrm{C}$ b) $\mathrm{TFA}, \mathrm{CH}_{2} \mathrm{Cl}_{2}$ c) $\mathrm{CH}_{2} \mathrm{O}, \mathrm{NaBH}_{3} \mathrm{CN}, \mathrm{AcOH}, \mathrm{MeOH}$ vii, $\mathrm{ArB}$ (pinacol), $3^{\text {rd }}$ generation $\mathrm{Pd}$ precatalyst, $\mathrm{P}(\mathrm{Cy})_{3} \cdot \mathrm{HBF}_{4}, \mathrm{~K}_{3} \mathrm{PO}_{4}$, dioxan-water, $130{ }^{\circ} \mathrm{C}$ then 
DEAD, $\mathrm{Me}_{2} \mathrm{NCH}_{2} \mathrm{CH}_{2} \mathrm{OH}, \mathrm{Ph}_{3} \mathrm{P}$, THF, $0{ }^{\circ} \mathrm{C}$ viii, a) $\mathrm{ArB}$ (pinacol), $\mathrm{Pd}$ dppf, $\mathrm{Cs}_{2} \mathrm{CO}_{3}$, dioxanwater, $130{ }^{\circ} \mathrm{C}$ b) TFA, $\mathrm{CH}_{2} \mathrm{Cl}_{2}$ c) acetone, $\mathrm{NaBH}_{3} \mathrm{CN}, \mathrm{AcOH}, \mathrm{CH}_{2} \mathrm{Cl}_{2}-\mathrm{MeOH}$ ix, $\mathrm{NaBH}_{3} \mathrm{CN}$, acetaldehyde or $\mathrm{CH}_{2} \mathrm{O}, \mathrm{AcOH}, \mathrm{CH}_{2} \mathrm{Cl}_{2}-\mathrm{MeOH}$ x, a) $\mathrm{CH}_{2} \mathrm{O}, \mathrm{NaBH}_{3} \mathrm{CN}, \mathrm{AcOH}$, $\mathrm{MeOH}$ b) TFA / $\mathrm{CH}_{2} \mathrm{Cl}_{2}$-water c) amine, $\mathrm{NaBH}_{3} \mathrm{CN}$, AcOH, $\mathrm{CH}_{2} \mathrm{Cl}_{2}-\mathrm{MeOH}$

\section{$\underline{\text { Results and discussion }}$}

Initial thiazolopyridone $\mathbf{1 3}$ met our criteria for a lead with excellent PI3K $\delta$ potency in both biochemical and cellular assays, very good selectivity against PI3K $\alpha$ and acceptable selectivity against PI3K $\beta$ and $\gamma$ (Table 1).

Table 1. SAR of $m$-benzylamines.

\begin{tabular}{|c|c|c|c|c|c|c|c|c|}
\hline \multirow[t]{2}{*}{ Compound } & \multirow[t]{2}{*}{$\mathrm{R}$} & \multicolumn{5}{|c|}{$\mathrm{PI} \mathrm{K} \mathrm{pIC}_{50}$} & \multirow{2}{*}{$\begin{array}{l}\text { Solubility } \\
\mu \mathrm{M}\end{array}$} & \multirow[t]{2}{*}{$\log D$} \\
\hline & & $\delta$ & $\alpha$ & $\beta$ & $\gamma$ & $\delta$ cell & & \\
\hline 13 & $\mathrm{H}$ & 9.4 & 6.2 & 7.3 & 7.9 & 9.2 & 77 & 2.7 \\
\hline $15 a$ & $\mathrm{CH}_{2} \mathrm{NH}_{2}$ & 9.2 & 5.9 & 8.1 & 6.7 & 7.4 & $>1000$ & -0.3 \\
\hline $15 b$ & $\mathrm{CH}_{2} \mathrm{NHMe}$ & 9.1 & 5.9 & 8.0 & 6.2 & 7.7 & $>1000$ & -0.2 \\
\hline $15 \mathrm{c}$ & $\mathrm{CH}_{2} \mathrm{NMe}_{2}$ & 9.1 & 5.5 & 7.2 & 6.2 & 8.8 & 956 & 0.8 \\
\hline $15 d$ & $\begin{array}{l}\mathrm{CH}_{2} \mathrm{NHCH}_{2} \mathrm{CH}_{2} \mathrm{O} \\
\mathrm{Me}\end{array}$ & 9.2 & 5.9 & 7.7 & 6.4 & 8.6 & $>1000$ & 0.7 \\
\hline $15 e$ & $\begin{array}{l}\mathrm{CH}_{2} \mathrm{~N}(\mathrm{Me}) \mathrm{CH}_{2} \mathrm{CH}( \\
\mathrm{Me})_{2}\end{array}$ & 9.3 & 5.7 & 7.0 & $<6.1$ & 9.2 & 12 & 2.3 \\
\hline $15 f$ & & 9.3 & 5.8 & 7.4 & 6.3 & 8.6 & 954 & 0.5 \\
\hline $15 \mathrm{~g}$ & $\begin{array}{l}\mathrm{CH}_{2} \mathrm{NH}\left(\mathrm{CH}_{2}\right)_{4} \mathrm{O}(\mathrm{C} \\
\left.\mathrm{H}_{2}\right)_{2} \mathrm{Ph}\end{array}$ & 9.4 & 6.3 & 8.1 & 6.5 & 8.9 & 699 & 2.3 \\
\hline
\end{tabular}

All biological values are mean of $\geq 3$ replicates

As a model for inhalation we dosed compounds by intra tracheal (i.t.) administration of a solution of compound to rats followed by termination at time-points up to $24 \mathrm{~h}$ and subsequent analysis of the residual compound in the lungs. Compound 13, a moderately 
soluble $(77 \mu \mathrm{M})$ neutral molecule, was cleared extremely rapidly from lung; compound could only be detected at the first time-point ( 3 minutes after dosing, table 2 ). Given the rapid clearance from the lung of the parent compound we needed to find a mechanism by which we could obtain duration. Two main strategies have been described to produce a prolonged effect in lung tissue: low solubility ${ }^{22,23}$ or basicity. ${ }^{24}$ Solubility-driven approaches require that material dissolves slowly over the time after dosing to produce the effect whilst a $\mathrm{pH}$-driven approach relies on dissolved compound being trapped in acidic organelles, such as lysosomes, which are prevalent in lung tissue, to provide a depot that is then released slowly over an extended period of time. We prioritised the addition of basic centres as a potentially predictable method to modulate lung retention.

Crystallisation of $\mathbf{1 3}$ in a murine PI3K $\delta$ construct (Figure 2) showed that the compound bound in a similar conformation and into the same induced pocket in the enzyme that has been described previously. ${ }^{16}$ Examination of the crystal structure revealed that there might be scope to extend from the meta position of the phenyl ring towards solvent if the phenyl ring made a small rotation, enabling modulation of the physical properties of the compounds without affecting the enzyme affinity.

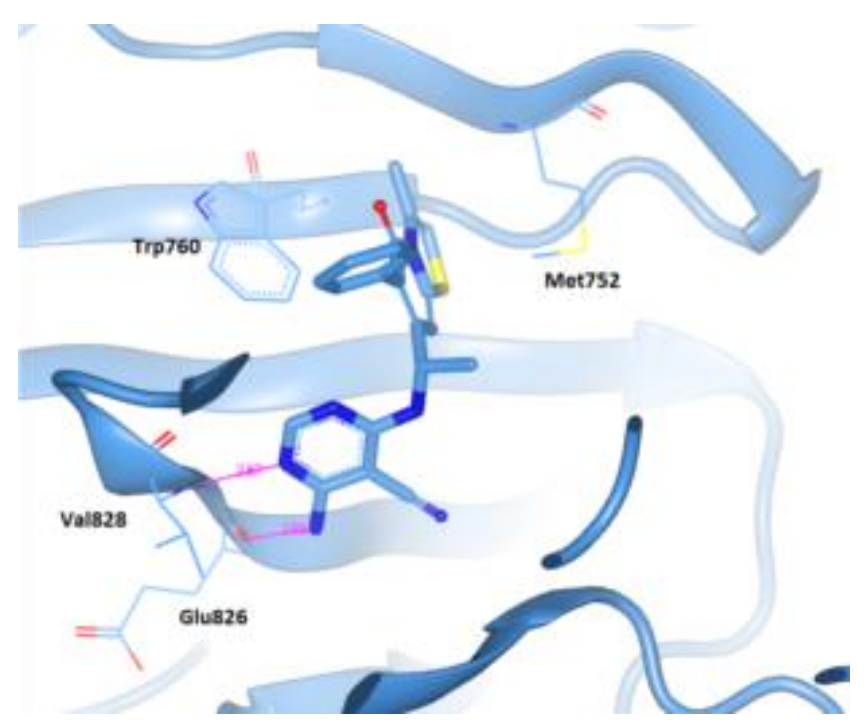


Figure 2. Compound $\mathbf{1 3}$ bound in murine PI3Kd showing the ATP binding pocket with the induced pocket between Trp760 and Met752 and with hydrogen bonds to the NH of Val828 and the carbonyl of Glu826 making the hinge interaction.

Table 2. Lung PK of compounds 13, 15a-g.

\begin{tabular}{|l|l|l|l|}
\hline Compound & $\begin{array}{l}\text { Lung } \\
\mathrm{t} 1 / 2 \\
\mathrm{~h}\end{array}$ & $\begin{array}{l}\text { Residual } \\
\text { dose at 4 h } \\
(\%)\end{array}$ & $\begin{array}{l}\text { Residual } \\
\text { dose at } \\
24 \mathrm{~h}(\%)\end{array}$ \\
\hline $\mathbf{1 3}$ & NA* $^{*}$ & 0 & 0 \\
\hline $\mathbf{1 5 a}$ & 1.6 & 2 & 0 \\
\hline $\mathbf{1 5 b}$ & 4.9 & 2.5 & 0 \\
\hline $\mathbf{1 5 c}$ & 2.3 & 0.2 & 0 \\
\hline $\mathbf{1 5 d}$ & 1.3 & 0.8 & 0 \\
\hline $\mathbf{1 5 e}$ & NA* & 0 & 0 \\
\hline $\mathbf{1 5 f}$ & 1.1 & 0.5 & 0 \\
\hline $\mathbf{1 5 g}$ & 3.5 & 4.8 & 0 \\
\hline
\end{tabular}

All time-points were a mean from 3 animals

* Compounds $13 \& 15$ e were only detected in lung tissue at the first time-point of the experiment (3 minutes after dosing) and then only $2 \%$ and $6.5 \%$ of the total dose respectively.

Addition of a benzylic amine to the meta position of the pendant phenyl in $\mathbf{1 3}$ gave compounds $(\mathbf{1 5 a}, \mathbf{b}, \mathbf{c})$ that retained the PI3K $\delta$ potency of 13 but exhibited differing selectivities towards the other isoforms. (Table 1) Addition of the basic centre increased selectivity towards PI3K $\gamma$ by reducing potency at that isoform, particularly for $\mathbf{1 5 b} \& \mathbf{c}$, thus increasing selectivity. Selectivity towards PI3K $\beta$ on the other hand was reduced for $\mathbf{1 5 a} \& \mathbf{b}$, though not for 15c. Selectivity against PI3K $\alpha$ was slightly increased, with $\mathbf{1 5 c}$ again the most selective. All three compounds had low lipophilicity, particularly $\mathbf{1 5 a} \& \mathbf{b}$, and these two 
showed a significant potency drop-off in the cell assay, probably reflecting poor cell permeability.

Crystallisation of $\mathbf{1 5 c}$ with PI3K $\delta$ (Figure 3) showed an almost complete superposition with the structure of $\mathbf{1 3}$ without rotation of the phenyl ring; the dimethylamino group, as expected, pointed into the solvent channel. The dimethylamino group lies in the proximity of Asn836 (PI3K $\delta$ ), the amide moiety of which can be seen to rotate slightly to accommodate the ligand; this is one of the few highly variable residues in the vicinity of the ATP binding site of the highly homologous PI3K isoforms. The corresponding residues in the other isoforms PI3K $\alpha$ Gln859, PI3K $\beta$ Asp856 and PI3K $\gamma$ Lys890 are all different. These differences can in part explain the observed selectivity changes, thus the positively charged protonated amines can make a favourable interaction with the aspartate anion of PI3K $\beta$ that is reflected in the increased potency at this isoform, but make an unfavourable one with the cation of Lys 890 in PI3K $\gamma$ accounting for the big drop in potency observed. The neutral glutamine in PI3K $\alpha$ has a more modest effect, but is a larger group than the asparagine in $\delta$ and thus the slight loss of potency as the size of the substituent increases from 15a to $\mathbf{b}$ to $\mathbf{c}$ can be understood. These effects were seen consistently for further examples $(\mathbf{1 5 d}-\mathbf{f})$ and consequently we shifted our focus to tertiary amines in this position to ensure we obtained sufficient selectivity vs. PI3K $\beta$.

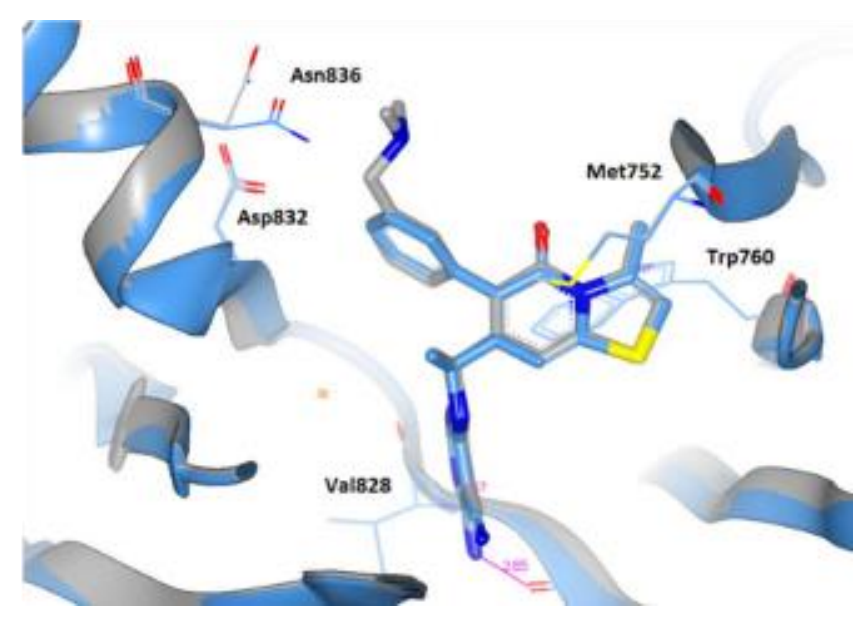


Figure 3. View of 15c (grey) overlayed with 13 (blue) showing the very similar conformations adopted by the ligands and the almost identical protein conformations. Note the movement of the sidechain amide of Asn836 permitting the dimethylamino group to be accommodated.

Larger N-substituents were tolerated, as expected based on this group pointing to solvent (Figure 4), and enzyme affinities at all four isoforms were remarkably consistent across the series 15a-g, barring the effect already mentioned with PI3K $\beta$. More lipophilic compounds however showed improved cell potencies, consistent with a potential favourable effect on membrane permeability (Table 1, Figure 5). We investigated the preferred location of the basic centre by making a series of changes to the linker length between the amine and the aromatic ring $(\mathbf{1 7}, \mathbf{1 8}, \mathbf{1 9}$, Table $\mathbf{3})$. As the distance between the amine and the aromatic ring increased beyond two atoms the potency at PI3K $\beta$ reduced, consistent with loss of a favourable interaction with Asp856; activity against the other isoforms was little changed. Once again cell potency dropped off for compounds with low LogD.

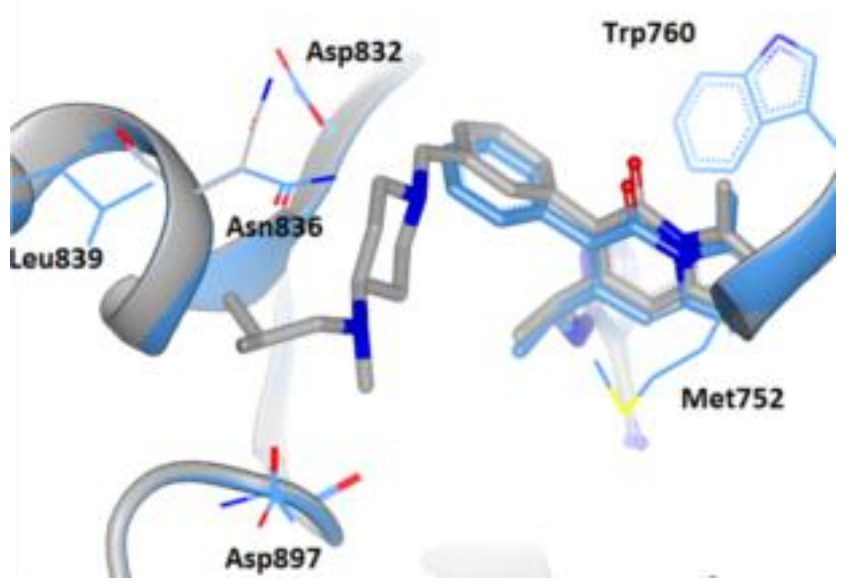

Figure 4. Docked structure of $20 f$ (grey) overlaid with 13 (blue) in murine PI3K showing the large substituted aminopiperidine accommodated in the solvent channel. 


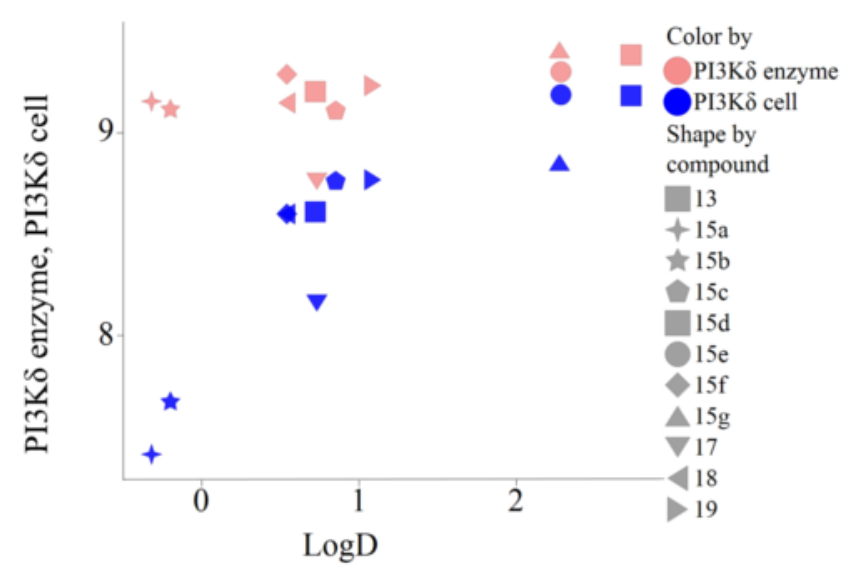

Figure 5. Enzyme and cell potencies for compounds 13, 15a-g, 17, 18, 19 showing cell drop-off at low lipophilicity.

Table 3. SAR of alternate positions for the base.

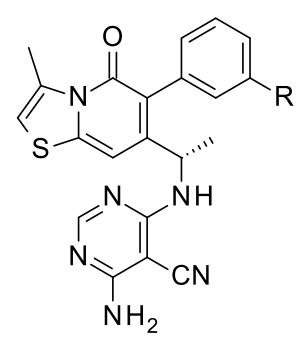

15c, 17-19

\begin{tabular}{|l|l|l|l|l|l|l|l|}
\hline Compound & $\mathrm{R}$ & $\begin{array}{l}\mathrm{PI} 3 \mathrm{~K} \delta \\
\mathrm{pIC}_{50}\end{array}$ & $\begin{array}{l}\mathrm{PI} 3 \mathrm{~K} \alpha \\
\mathrm{pIC}\end{array}$ & $\begin{array}{l}\mathrm{PI} 3 \mathrm{~K} \beta \\
\mathrm{pIC}\end{array}$ & $\begin{array}{l}\mathrm{PI} 3 \mathrm{~K} \gamma \\
\mathrm{pIC}\end{array}$ & $\begin{array}{l}\mathrm{PI} 3 \mathrm{~K} \delta \\
\text { cell } \\
\mathrm{pIC}\end{array}$ & $\begin{array}{l}\text { Log } \\
\mathrm{D}\end{array}$ \\
\hline $\mathbf{1 5 c}$ & $\mathrm{CH}_{2} \mathrm{NMe}_{2}$ & 9.1 & 5.5 & 7.2 & 6.2 & 8.8 & 0.8 \\
\hline $\mathbf{1 7}$ & $\mathrm{CH}_{2} \mathrm{CH}_{2} \mathrm{NMe}_{2}$ & $9.1^{\dagger}$ & $5.9^{\dagger}$ & $7.3^{\dagger}$ & $<6.0^{\dagger}$ & $8.6^{\ddagger}$ & 0.5 \\
\hline $\mathbf{1 8}$ & $\mathrm{OCH}_{2} \mathrm{CH}_{2} \mathrm{NMe}_{2}$ & 8.8 & 5.1 & 6.7 & 6.5 & 8.2 & 0.7 \\
\hline $\mathbf{1 9}$ & & 9.2 & 6.0 & 6.4 & 6.6 & 8.8 & 1.1 \\
\hline
\end{tabular}


In contrast to compound $\mathbf{1 3}$, i.t. dosing of $\mathbf{1 5 a - g}$ to rat lung showed measureable half-lives for all except 15e, but the vast majority of compound was still cleared within a short period and negligible compound was present $24 \mathrm{~h}$ after dosing for any of the compounds. (Table 2) We focussed on the amount of compound retained at 4 and $24 \mathrm{~h}$ to guide our design rather than the half-life as the latter reflected the terminal $\beta$-phase only and did not account for differences in the amount of compound lost in the rapid initial $\alpha$-phase, which was often $>99 \%$ (Figure 5). Compounds 15e and $\mathbf{g}$ both met the criteria of Austin et $\mathrm{al}^{25}$ for obtaining duration with inhaled $\beta$-agonists $(\mathrm{pKa}>8, \log \mathrm{D}>2$; $\mathrm{pKa}$ could not be determined for $15 \mathbf{e}$ but related tertiary benzylamines had $\mathrm{pKa}>9$; pKa $\mathbf{1 5 g}=9.4)$. The long phenylethoxyalkyl chain of $\mathbf{1 5 g}$ was modelled on that used for $\beta$-agonists like Salmeterol and Sibenadet. ${ }^{26}$ Despite these precedents $\mathbf{1 5 e}$ was barely retained at all in lung whilst $\mathbf{1 5 g}$, though having the greatest retention of this group of compounds, still exhibited insufficient lung residence for our purposes.

In parallel with our investigations of basic sidechains we sought to investigate dibasic analogues. (Table 4) The first two compounds synthesised (20a, b) were highly potent PI3K $\delta$ inhibitors. As with the monobases the secondary amine 20a was less selective against PI3K $\beta$ then the tertiary amine $\mathbf{2 0 b}$. Both compounds showed reduced cell potency, consistent with their low lipophilicities. When dosed IT to rats 20b, but not 20a, showed excellent lung retention with both a long half-life and a substantial proportion of the dose remaining in the lung $24 \mathrm{~h}$ after dosing (table 4, Figure 6). For 20b there was still an initial $\alpha$-phase with a rapid decrease of compound over the first 30 minutes, followed by a prolonged $\beta$-phase where the levels declined slowly however dibase 20b exhibited the base-driven PK profile that we were seeking for our compounds.

Table 4. Data for dibasic compounds 20a-l. 
<smiles>CCCc1cccc(-c2c(CC)cc3scc(C)n3c2=O)c1</smiles><smiles>N#Cc1c(N)ncnc1N</smiles><smiles>CC(C)NCCN1CCOCC1</smiles><smiles>CC(C)N1CCC(N(C)CCC(F)(F)F)CC1</smiles>
$20 \mathrm{i}$<smiles>CN(C)CCCN(C)Cc1ccc(Cl)cc1</smiles><smiles>CCN1CCC(N(C)C)CC1</smiles><smiles>CCN1CCC(N(C)CC(C)C)CC1</smiles><smiles>CC1CN(CCCN(C)C)CC(C)O1</smiles><smiles>CC(C)CN(C)CC1CCN(CC(C)([O-])[18OH])CC1</smiles><smiles>CCN1CCC(CN(C)Cc2ccccn2)CC1</smiles><smiles>CC(C)N1CCN(CCN2CCOCC2)CC1</smiles><smiles>CCN(CC)CCN1CCOCC1</smiles><smiles>CCN(C)CCCCN1CC(C)OC(C)C1</smiles>
201<smiles>CN(C)CCCCN(C)Cc1ccccc1</smiles>

\begin{tabular}{|c|c|c|c|c|c|c|c|c|c|}
\hline Compound & $\begin{array}{l}\mathrm{PI} 3 \mathrm{~K} \delta \\
\mathrm{pIC}_{50}\end{array}$ & $\begin{array}{l}\mathrm{PI} 3 \mathrm{~K} \beta \\
\mathrm{pIC}_{50}\end{array}$ & $\begin{array}{l}\text { PI3K } \delta \\
\text { cell } \\
\text { pIC }_{50}\end{array}$ & $\log D$ & $\mathrm{Clog} \mathrm{P}$ & $\begin{array}{l}\mathrm{pKa} \\
\mathrm{B} 1\end{array}$ & $\begin{array}{l}\mathrm{pKa} \\
\mathrm{B} 2\end{array}$ & $\begin{array}{l}\text { Lung } \\
t^{1 / 2} \\
h\end{array}$ & $\begin{array}{l}\text { Residual } \\
\text { dose at } \\
24 \mathrm{~h}(\%)\end{array}$ \\
\hline $20 a$ & 9.2 & 7.7 & 7.9 & 0.6 & 2.7 & 9.6 & 4.7 & 4.2 & 0.1 \\
\hline $20 \mathrm{~b}$ & 9.3 & 7.2 & 8.0 & 0.5 & 2.7 & 9.5 & 6.5 & 23.2 & 4.8 \\
\hline $20 c$ & 9.2 & 7.3 & 8.6 & 2.1 & 4.8 & 9.8 & 8.0 & 12 & 3.3 \\
\hline 20d & 9.1 & 7.0 & 9.0 & 2.5 & 3.5 & 8.4 & 5.4 & 4.5 & 0.2 \\
\hline $20 \mathrm{e}$ & 8.8 & 6.6 & 7.9 & 1.1 & 2.6 & 7.3 & 6.0 & 8.7 & 3.5 \\
\hline $20 f$ & 9.2 & 7.1 & 8.9 & 1.7 & 4.2 & 9.7 & 6.8 & 9.9 & 2.8 \\
\hline $20 \mathrm{~g}$ & 9.1 & 7.2 & 8.7 & 2.0 & 3.8 & 9.0 & 7.0 & 10.9 & 5.2 \\
\hline $20 \mathrm{~h}$ & 9.1 & 6.6 & 8.9 & 1.4 & 3.8 & 8.0 & 4.0 & 0.0 & 0.0 \\
\hline $20 \mathrm{i}$ & 9.2 & 7.9 & 8.5 & 3.2 & 6.1 & 8.8 & 7.5 & 13 & 3.3 \\
\hline $20 j$ & 8.9 & 6.9 & 8.3 & 1.5 & 4.4 & 8.5 & 5.7 & 5.9 & 0.8 \\
\hline $20 k$ & 8.9 & 7.1 & 8.2 & 1.5 & 4.3 & 8.9 & 6.3 & 7.6 & 3.9 \\
\hline 201 & 9.3 & 7.8 & 8.7 & 2.2 & 5.1 & 9.1 & 7.0 & 17.6 & 7.4 \\
\hline
\end{tabular}


$\mathrm{pIC}_{50}$ values for PI3K $\alpha$ and $\gamma$ not shown; these were consistently low $(\alpha \leq 6.2, \gamma \leq 6.7)$ All biological values are means of $\geq 3$ replicates

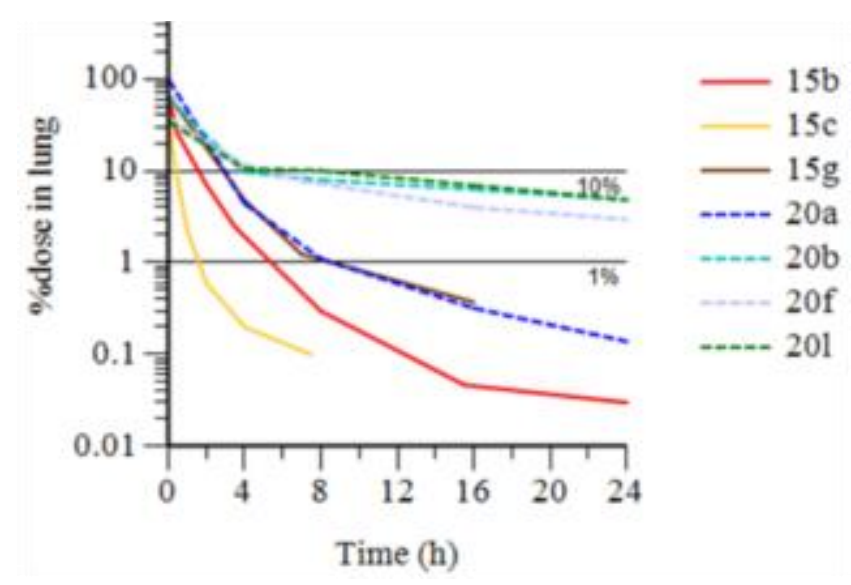

Figure 6. Rat ITPK time-course profiles of selected examples.

This left the question of why $\mathbf{2 0 b}$ but not 20a was retained in lung? Previous work $^{16}$ has described the benefits of dibases for lung retention, but the precise basicities required have not been defined. Measured pKas for the two compounds were surprisingly different, with the second pKa for $\mathbf{2 0 b}$ being markedly higher than that of 20a (6.5 vs. 4.7). To investigate this effect further we synthesised a set of compounds with a range of pKas for both basic centres (Table 4). Inevitably these compounds (20c - I) also had varying lipophilicities; thus we also investigated the role of lipophilicity on both cell potency and PK. (Figures $7 \&$ 8) 

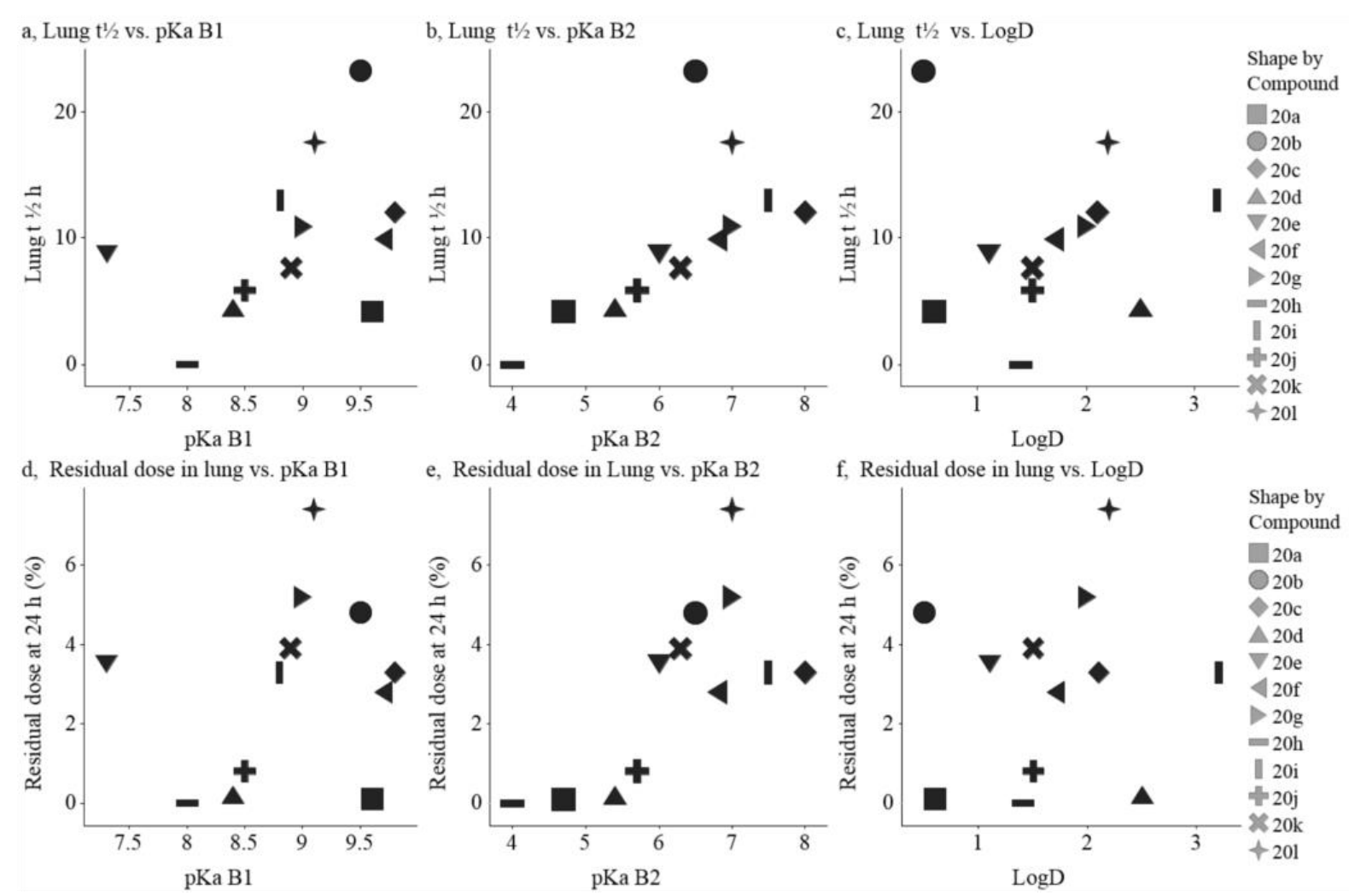

Figure 7. Relationships between lung retention (\% remaining at $24 \mathrm{~h}$; half-life) and the first and second pKas or Lipophilicity ( $\log \mathrm{D})$ for dibases

Examination of Figure 7 shows that, for the range of variables tested, the second (weaker) basic $\mathrm{pKa}$ is the most significant factor $(\mathbf{6 b} \& \mathbf{e})$. Thus for compounds with a second $\mathrm{pKa}$ less than $5(\mathbf{2 0 a}, \mathbf{2 0 h})$ half-life is short $(<4 \mathrm{~h})$ and essentially no compound is retained in the lung at $24 \mathrm{~h}$. As the second $\mathrm{pKa}$ is increased the half-life increases but until the second $\mathrm{pKa}$ reaches $>\sim 6$ only a small fraction is retained in the lung after $24 \mathrm{~h}$. With a low second pKa changes in lipophilicity have little effect (20a vs. 20h; 20d vs. 20j). For compounds where the second $\mathrm{pKa}$ is greater than 6 further increases provide, in general, an increased lung halflife, but the effect on the absolute retention is less well defined. The first pKa $(\mathbf{6 a} \& \mathbf{d})$ appears not to play a significant role in the retention of compounds in the lung over the range of values in this series of compounds (lowest $\mathrm{pKa} B 1$ 7.2). Lipophilicity, as determined by $\log \mathrm{D}$ (also similarly for CLogP, data not shown) does not appear to affect the amount of dose 
remaining after $24 \mathrm{~h}(\mathbf{6 f})$, but does appear to contribute in a small way to the lung half-life $(6 \mathbf{c})$.

There are two significant outliers to the analysis described above, compounds $\mathbf{2 0 b} \& \mathbf{2 0 1}$. For both of these compounds the half-life is surprisingly long; 201 also has the highest percentage of sample remaining in the lung after $24 \mathrm{~h}$. 201 was designed to contain an aralkyl chain similar to that used to improve retention in $\beta$-agonists, ${ }^{26}$ however the structurally related compound 20i does not exhibit any marked effect on retention. (Both 20i and 201 surprisingly showed a decreased selectivity towards PI3K $\beta$ which ruled out 201 from further progression despite the excellent lung retention.)

We rationalise these results as implying that lung retention is driven by trapping of a dication in lung lysosomes $\left(\mathrm{pH} 4.5-5^{27}\right)$. The monocation is membrane permeable and the rate of escape from the lysosome and hence half-life is driven by the fraction of monocation, affected by the second $\mathrm{pKa}$, and lipophilicity. The effect of lipophilicity on half-life probably principally derives from the greater membrane affinity of the more lipophilic compounds, thus the longest half-life belongs to the least lipophilic dibase 20b. Additional structural features, like the long aralkyl chain of 201, also affect the rate of membrane permeability.

The most important driver of cell-potency appears to be the lipophilicity (Table 4, Figure 8). (Compounds where the second $\mathrm{pKa}$ is less than 6 are excluded from this analysis as they behave more like monobases.) If $\log \mathrm{D}$ is greater than approximately 1.6 then a compound with good enzyme inhibition will also have good cell potency. When a larger and more diverse set of dibases were examined (data not shown) the same trend was still apparent, with a lower cut-off of LogD $c a 1.4$ and an upper cut-off of $c a 2.8$, though structural variations did have an additional effect. 


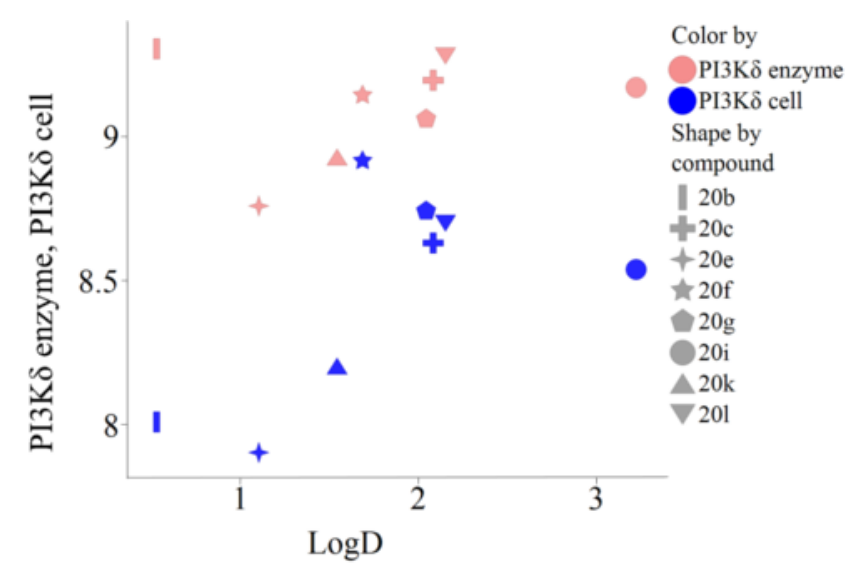

Figure 8. Cell drop-off for dibases.

Compounds $\mathbf{2 0 b} \& \mathbf{f}$ were selected for further study based on their good lung retention, high potency coupled with isoform selectivity and, for $\mathbf{2 0 f}$, excellent cell potency. Both of these compounds were screened against a panel of 345 kinases, neither showed $>50 \%$ activity at any other kinase at $1 \mu \mathrm{M}$. Neither compound showed significant inhibition of the hERG ion channel, despite containing basic centres $(<20 \%$ inhibition at $11 \mu \mathrm{M})$.

Dosing to rats both IV and PO (table 5) showed that the compounds had negligible oral bioavailability and high systemic clearance with 20 f exhibiting clearance greater than liver blood flow, implying that extrahepatic mechanisms were involved. These results gave us confidence that systemic exposure of these two compounds when dosed by inhalation would be low.

Table 5 Rat Pharmacokinetics IV and PO.

\begin{tabular}{|l|l|l|l|l|}
\hline Example & $\begin{array}{l}\text { IV Clearance } \\
\mathrm{mL} / \mathrm{min} / \mathrm{kg}\end{array}$ & $\begin{array}{l}\mathrm{t} 1 / 2 \\
\mathrm{~h}\end{array}$ & $\begin{array}{l}\text { Vss } \\
\mathrm{L} / \mathrm{kg}\end{array}$ & $\begin{array}{l}\text { Oral bioavailability } \\
\%\end{array}$ \\
\hline 20b & 57 & 12 & 12 & $<1$ \\
\hline 20f & 150 & 11 & 88 & $<1$ \\
\hline
\end{tabular}


To study the effects of the compounds in an inhaled setting we used a transgenic mouse model as a mechanistic model of T-cell activation. Briefly transgenic mice (OTII strain, genetically sensitised to ovalbumin ${ }^{28}$ ) were challenged with ovalbumin (dosed i.t.) and then, after a week, dosed with compound (i.t. administration) $2 \mathrm{~h}$ prior to a challenge with intranasal anti-CD3. The animals were terminated $6 \mathrm{~h}$ after challenge and the inhibition of the formation of phospho S6 ribosomal protein (pS6RP) by compound was determined as a biomarker for the inhibition of PI3K $\delta .^{29} \mathbf{2 0 b}$ showed good activity in this model with a clear dose response, although a high dose was required to achieve full effect (Figure 9a). When 20f was dosed similarly a significant effect was observed, however instead of the 10-fold improvement in efficacy that we were hoping to see, based on the significantly better cell potency of this compound, the effect appeared to be weaker. (Figure 9b).

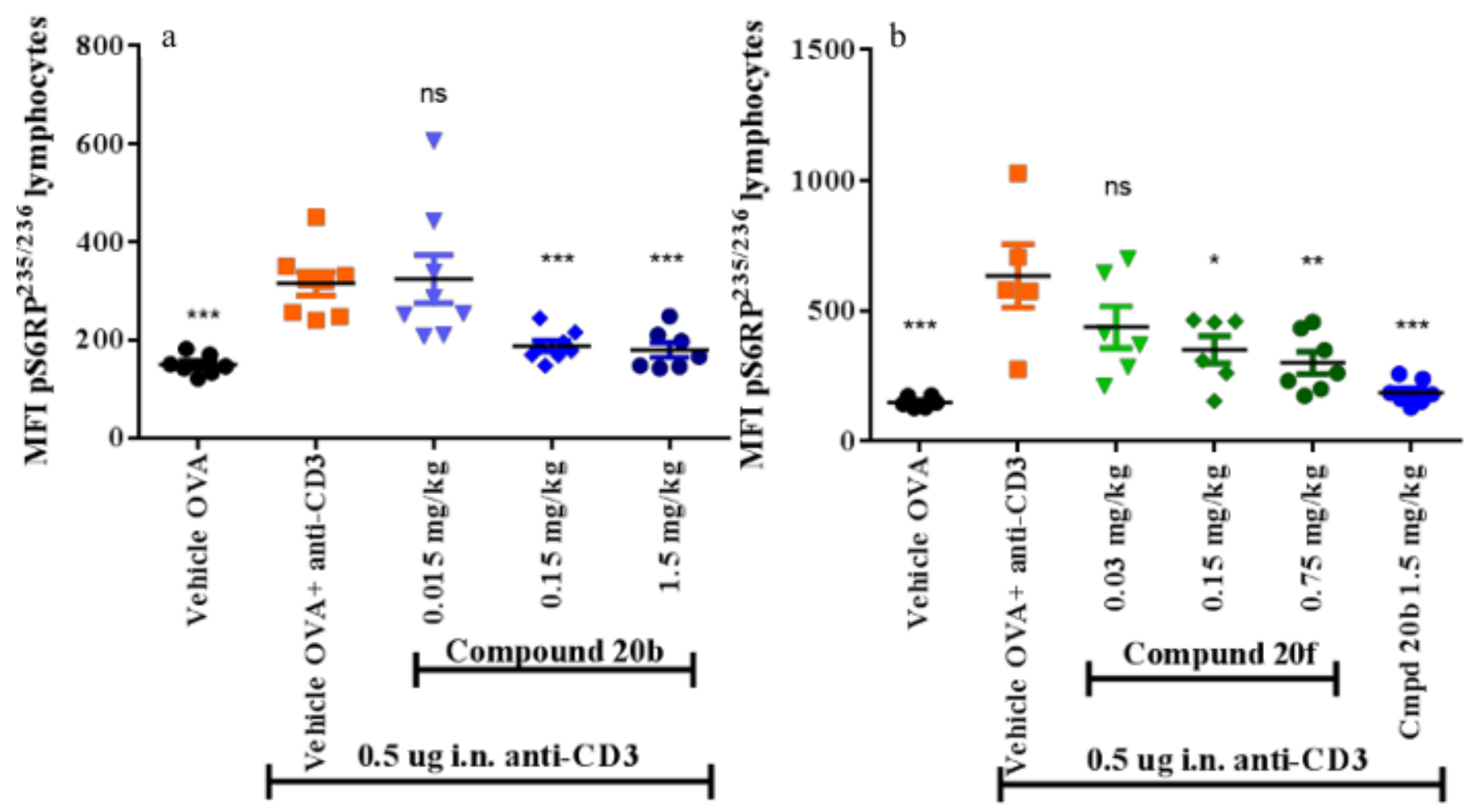

Figure 9. Inhibition of pS6RP in lung lavage after anti-CD3 challenge to OTII mice. 9a compound 20b 9b compound 20f. Target engagement of PI3K $\delta$ activity is shown through 
measurements of pS6RP in bronchoalveolar lung lavage cells after anti-CD3 challenge to OVA-challenged OTII mice. Phosphorylation of S6RP, measured using phosphospecific antibodies, was significantly inhibited by both $20 \mathbf{b}(9 \mathrm{a})$ and $20 \mathrm{f}(9 \mathrm{~b})$ in a dose-dependent manner, however the inhibition by $\mathbf{2 0 b}$ showed better potency. Data is shown as results for individual animals at each dose with the statistical significance indicated as follows above the columns : $p<0,001 * * * ; p<0,005 * * ; p<0,05 *$

This result left us with the question of why the more potent compound in vitro appeared to be less effective in-vivo? Our rationalisation is that although $\mathbf{2 0 f}$ is retained in the lung effectively we do not know the available levels of drug at the target in the lung. Compound in the lung is expected to be partitioned between acidic organelles, membranes and lung fluid. Different ratios in this partitioning will produce differing concentrations of free drug available to act on the T-cells that drive the observed results. It is also believed that, for highly permeable compounds such as this series, free drug in lung partitions rapidly into the systemic circulation. Given the very high systemic clearance of these compounds it is unlikely that an equilibrium can be achieved and instead that free drug in the lung will continually be lost to the systemic circulation, resulting in very low lung free levels, once the initial dose has distributed. Based on this analysis we concluded that unfortunately the combination of a lipophilic dibasic molecule with the very high systemic clearance exhibited by this series was unlikely to deliver a compound with sufficient in-vivo potency to be capable of being administered at the low dose necessitated by inhaled delivery and that we would require a different chemical series with alternative properties to deliver the effect that we desired.

\section{Conclusions}

We have identified a novel scaffold with excellent potency against PI3K $\delta$ and good selectivity against the other isoforms, particularly PI3K $\alpha$. Guided by crystal structure information we identified a region where we were able to make changes without significantly affecting biochemical potency against 


\begin{abstract}
PI3K $\delta$ and were able to identify how to maintain selectivity against PI3K $\beta$. By exploration of the physical properties of the compounds we were able to identify regions of property space where significant lung retention over $24 \mathrm{~h}$ and good cell potency were achievable. From within this property space compounds suitable for further study were identified and we were able to show an effect in a PD model with i.t. dosing.
\end{abstract}

\title{
Chemical Experimental
}

All reagents obtained from commercial sources were used without further purification; anhydrous solvents were used without further drying. All compounds were purified to $\geq 95 \%$ purity as judged by HPLC with uv and MS analysis. When $\mathrm{Cl}$ or $\mathrm{Br}$ was present, expected isotopic distribution patterns were observed. Details of the analytical conditions and observed purities are contained in the Supporting Information. Proton $\left({ }^{1} \mathrm{H}\right)$ and carbon $\left({ }^{13} \mathrm{C}\right) \mathrm{NMR}$ spectra were recorded at ambient temperature. Solutions were typically prepared in deuterated dimethyl sulfoxide (DMSO- $\left.\mathrm{d}_{6}\right)$, deuteromethanol $\left(\mathrm{CD}_{3} \mathrm{OD}\right)$ or duterochloroform $\left(\mathrm{CDCl}_{3}\right)$ with chemical shifts referenced to solvent as an internal standard. ${ }^{1} \mathrm{H}$ NMR data are reported indicating the chemical shift $(\delta)$, the multiplicity (s, singlet; d, doublet; $t$, triplet; $q$, quartet; m, multiplet; br, broad; dd, doublet of doublets; etc.), the coupling constant ( $\mathrm{J})$ in $\mathrm{Hz}$, and the integration (e.g., 1H).

\section{5-[(2R)-2-Chloro-1-hydroxypropylidene]-2,2-dimethyl-1,3-dioxane-4,6-dione (3)}

A 20 L 4-necked round-bottom flask was charged with (2R)-2-chloropropanoic acid (450 g, $4.15 \mathrm{~mol})$ in dichloromethane (9 L), 2,2-dimethyl-1,3-dioxane-4,6-dione (600 g, $4.16 \mathrm{~mol})$ and 4-dimethylaminopyridine (560 g, $4.58 \mathrm{~mol})$. A solution of DCC (946 g, $4.58 \mathrm{~mol})$ in dichloromethane $(2 \mathrm{~L})$ was added dropwise with stirring at $0{ }^{\circ} \mathrm{C}$. The resulting solution was stirred for $3 \mathrm{~h}$ at room temperature, recooled to $0{ }^{\circ} \mathrm{C}$ and was then quenched by the addition of $10 \mathrm{~L}$ of $6 \% \mathrm{KHSO}_{4}$. The mixture was filtered and the filtrate was extracted with $4 \times 15 \mathrm{~L}$ of dichloromethane. The combined organic layers were washed with $15 \mathrm{~L}$ of brine. The mixture 
was dried over sodium sulfate and concentrated under vacuum. The residue was chromatographed (silica gel; PE:EtOAc (10:1)) to give the title compound (460 g, 47\%) as a red oil.

${ }^{1} \mathrm{H}$ NMR (300 MHz, $\left.\mathrm{CDCl}_{3}\right) \delta 1.72-1.77(\mathrm{~m}, 9 \mathrm{H}), 6.05(\mathrm{q}, J=6.8 \mathrm{~Hz}, 1 \mathrm{H}), 15.58(\mathrm{~s}, 1 \mathrm{H})$; $\mathrm{m} / \mathrm{z}(\mathrm{ESI}) 232.9[\mathrm{M}-\mathrm{H}]^{-}$.

\section{7-[(1R)-1-Chloroethyl]-3-methyl-2H,3H,5H-[1,3]thiazolo[3,2-a]pyridin-5-one (4)}

A 20 L 4-necked round-bottom flask was charged with 2,4-dimethyl-4,5-dihydro-1,3thiazole $^{30}$ (650 g, $\left.5.64 \mathrm{~mol}\right)$, DCE (6.5 L), trifluoroacetic acid (643 g, $\left.5.64 \mathrm{~mol}\right)$ and TFAA (1185 g, $5.64 \mathrm{~mol})$. The mixture was stirred to get a solution and was heated to $50{ }^{\circ} \mathrm{C}$. A solution of 5-[(2R)-2-chloro-1-hydroxypropylidene]-2,2-dimethyl-1,3-dioxane-4,6-dione (3, $3971 \mathrm{~g}, 16.92 \mathrm{~mol}$ ) in DCE (4 L) was added dropwise over $2 \mathrm{~h}$. The resulting solution was stirred overnight at $50{ }^{\circ} \mathrm{C}$ and then allowed to cool to $\mathrm{RT}$. The $\mathrm{pH}$ was adjusted to 8 with aq. sodium bicarbonate and the resulting solution was extracted with $3 \times 10 \mathrm{~L}$ of dichloromethane and the organic layers were combined. The resulting mixture was washed with 1 x $10 \mathrm{~L}$ of brine, dried over anhydrous magnesium sulfate, concentrated and chromatographed (silica gel, ethyl acetate/petroleum ether (1:2-1:1)) to give the title compound (668 g, 52\%) as a red oil.

\footnotetext{
${ }^{1} \mathrm{H}$ NMR (400 MHz, $\left.\mathrm{CDCl}_{3}\right) \delta 1.49(\mathrm{~d}, J=6.4 \mathrm{~Hz}, 3 \mathrm{H}), 1.71(\mathrm{~d}, J=6.8 \mathrm{~Hz}, 3 \mathrm{H}), 2.97(\mathrm{~d}, J$ $=11.1 \mathrm{~Hz}, 1 \mathrm{H}), 3.67(\mathrm{dd}, J=11.1,7.5 \mathrm{~Hz}, 1 \mathrm{H}), 4.73(\mathrm{q}, J=6.8 \mathrm{~Hz}, 1 \mathrm{H}), 5.2-5.3(\mathrm{~m}, 1 \mathrm{H})$, $6.21(\mathrm{~s}, 1 \mathrm{H}), 6.22(\mathrm{~s}, 1 \mathrm{H})) ; \mathrm{m} / \mathrm{z}(\mathrm{ESI}) 230 / 232\left(\mathrm{Cl}\right.$ pattern) $[\mathrm{M}+\mathrm{H}]^{+}$.
}

\section{6-Bromo-7-[(1R)-1-chloroethyl]-3-methyl-2H,3H,5H-[1,3]thiazolo[3,2-a]pyridin-5-one} (5)

A 10 L 4-necked round-bottom flask was charged with 7-[(1R)-1-chloroethyl]-3-methyl2H,3H,5H-[1,3]thiazolo[3,2-a]pyridin-5-one (4, $312 \mathrm{~g}, 1.36 \mathrm{~mol})$, dichloromethane (6 L), $\mathrm{HBr}$ (40\% aq, $288 \mathrm{~g}, 1.42 \mathrm{~mol})$ and cooled to $-10{ }^{\circ} \mathrm{C}$. 3-Methylbutyl nitrite (318 g, $\left.2.72 \mathrm{~mol}\right)$ was added dropwise with stirring and the resulting solution was stirred overnight at $-5{ }^{\circ} \mathrm{C}$. The 
solution was diluted with $3 \mathrm{~L}$ of $\mathrm{CH}_{2} \mathrm{Cl}_{2}$ and was washed sequentially with $2 \times 3 \mathrm{~L}$ of satd. sodium bicarbonate, $2 \times 3 \mathrm{~L}$ of $10 \% \mathrm{Na}_{2} \mathrm{~S}_{2} \mathrm{O}_{3}$ and $3 \mathrm{~L}$ of brine, then dried $\left(\mathrm{MgSO}_{4}\right)$, filtered and concentrated. The residue was chromatographed (silica gel; ethyl acetate/petroleum ether (1:2)) to give the title compound (295 $\mathrm{g}, 70 \%)$ as a yellow solid.

\footnotetext{
${ }^{1} \mathrm{H}$ NMR $\left(300 \mathrm{MHz}, \mathrm{CDCl}_{3}\right) \delta 1.52(\mathrm{~d}, J=6.4 \mathrm{~Hz}, 3 \mathrm{H}), 1.70(\mathrm{~d}, J=6.8 \mathrm{~Hz}, 3 \mathrm{H}), 3.00(\mathrm{~d}, J$ $=11.2 \mathrm{~Hz}, 1 \mathrm{H}), 3.65-3.76(\mathrm{~m}, 1 \mathrm{H}), 5.24-5.34(\mathrm{~m}, 1 \mathrm{H}), 5.34-5.44(\mathrm{~m}, 1 \mathrm{H}), 6.40(\mathrm{~d}, J=$ $2.5 \mathrm{~Hz}, 1 \mathrm{H})) ; \mathrm{m} / \mathrm{z}$ (ESI) 308/310/312 (BrCl pattern) $[\mathrm{M}+\mathrm{H}]^{+}$.
}

\section{6-Bromo-7-[(1R)-1-chloroethyl]-3-methyl-5-oxo-2,3-dihydro-5H-[1,3]thiazolo[3,2-}

\section{a]pyridin-1-ium-1-olate (6)}

A 5 L 4-necked round-bottom flask was charged with 6-bromo-7-[(1R)-1-chloroethyl]-3methyl-2H,3H,5H-[1,3]thiazolo[3,2-a]pyridin-5-one $\quad(5, \quad 290 \quad \mathrm{~g}, \quad 940 \quad \mathrm{mmol})$ and dichloromethane $(3 \mathrm{~L})$. The resulting solution was cooled to $0{ }^{\circ} \mathrm{C}$ whereupon $\mathrm{m}$-CPBA (178 g, $1.0 \mathrm{~mol}$ ) was added in several batches. The resulting solution was stirred for $3 \mathrm{~h}$ and was then quenched by the addition of $2 \mathrm{~L}$ of sat. $\mathrm{NaHCO}_{3}$. The resulting solution was extracted with $3 \times 3 \mathrm{~L}$ of dichloromethane and the organic layers were combined, dried $\left(\mathrm{MgSO}_{4}\right)$ and concentrated. The residue was chromatographed (silica gel; ethyl acetate/petroleum ether $(1: 1-1: 0))$ to give the title compound $(223 \mathrm{~g}, 73 \%)$ as a yellow solid.

2 diastereomers in ca. 1:1 mixture : ${ }^{1} \mathrm{H}$ NMR $\left(300 \mathrm{MHz}, \mathrm{CDCl}_{3}\right) \delta 1.75,1.79(2 \times \mathrm{d}, J=6.8$ $\mathrm{Hz}, 3 \mathrm{H}), 1.86(\mathrm{~d}, J=6.7 \mathrm{~Hz}, 3 \mathrm{H}), 3.14-3.35(\mathrm{~m}, 2 \mathrm{H}), 5.37-5.53(\mathrm{~m}, 2 \mathrm{H}), 7.16,7.18(2 \times \mathrm{s}$, 1H)); m/z (ESI) 324/326/328 (BrCl pattern) $[\mathrm{M}+\mathrm{H}]^{+}$.

\section{6-Bromo-7-[(1R)-1-chloroethyl]-3-methyl-5H-[1,3] thiazolo[3,2-a]pyridin-5-one (7)}

A 5 L round-bottom flask was charged with 6-bromo-7-[(1R)-1-chloroethyl]-3-methyl-5oxo-2,3-dihydro-5H-[1,3]thiazolo[3,2-a]pyridin-1-ium-1-olate (6, $223 \mathrm{~g}, 687 \mathrm{mmol})$, toluene $(2.3 \mathrm{~L})$ and trifluoroacetic anhydride $(721 \mathrm{~g}, 3.43 \mathrm{~mol})$. The resulting solution was heated to $60{ }^{\circ} \mathrm{C}$ for $3 \mathrm{~h}$, then allowed to cool and concentrated. The residue was dissolved in 
dichloromethane $(250 \mathrm{~mL})$ which was added dropwise to cooled $\left(0^{\circ} \mathrm{C}\right)$ sulfuric acid $(98 \%$, 1.3 L) with stirring. The resulting solution was stirred for $1 \mathrm{~h}$ at RT. The reaction was poured onto water/ice and the resulting mixture was extracted with $4 \times 1 \mathrm{~L}$ of dichloromethane. The organic layers were combined, washed sequentially with $2 \times 1 \mathrm{~L}$ of sodium bicarbonate and 1 $\mathrm{L}$ of brine, dried $\left(\mathrm{MgSO}_{4}\right)$, concentrated and chromatographed (silica gel; ethyl acetate/petroleum ether (1:5-1:2)) to give the title compound (121 g, 55\%) as a yellow solid.

${ }^{1} \mathrm{H}$ NMR $\left(300 \mathrm{MHz}, \mathrm{CDCl}_{3}\right) \delta 1.76(\mathrm{~d}, J=6.8 \mathrm{~Hz}, 3 \mathrm{H}), 2.88(\mathrm{~s}, 3 \mathrm{H}), 5.48$ (q, $J=6.7 \mathrm{~Hz}$, 1H), $6.34-6.54(\mathrm{~m}, 1 \mathrm{H}), 6.91(\mathrm{~s}, 1 \mathrm{H})) ; \mathrm{m} / \mathrm{z}(\mathrm{ESI}) 308[\mathrm{M}+\mathrm{H}]^{+}$.

\section{7-[(1S)-1-Azidoethyl]-6-bromo-3-methyl-5H-[1,3]thiazolo[3,2-a]pyridin-5-one (8)}

A 2 L 4-necked round-bottom flask was charged with 6-bromo-7-[(1R)-1-chloroethyl]-3methyl-5H-[1,3]thiazolo[3,2-a]pyridin-5-one (7, $118 \mathrm{~g}, 366 \mathrm{mmol})$, N,N-dimethylformamide (1.2 L), TEA (3.88 g, $38 \mathrm{mmol})$ and $\mathrm{NaN}_{3}(27.5 \mathrm{~g}, 423 \mathrm{mmol})$. The resulting solution was stirred for $5 \mathrm{~h}$ at $45^{\circ} \mathrm{C}$, allowed to cool to room temperature and poured onto water/ice. The resulting mixture was extracted with $4 \times 800 \mathrm{~mL}$ of dichloromethane and the organic layers were combined, washed sequentially with $10 \times 1 \mathrm{~L}$ of $5 \% \mathrm{NaCl}$, dried $\left(\mathrm{MgSO}_{4}\right)$ and filtered to give a yellow solution of the title compound that was used without further purification.

${ }^{1} \mathrm{H}$ NMR (400 MHz, $\left.\mathrm{CDCl}_{3}\right) \delta 1.51(\mathrm{~d}, J=6.7 \mathrm{~Hz}, 3 \mathrm{H}), 2.90(\mathrm{~d}, J=1.2 \mathrm{~Hz}, 3 \mathrm{H}), 5.12(\mathrm{q}, J$ $=6.7 \mathrm{~Hz}, 1 \mathrm{H}), 6.47(\mathrm{~d}, J=1.2 \mathrm{~Hz}, 1 \mathrm{H}), 6.77(\mathrm{~s}, 1 \mathrm{H}), 7.28(\mathrm{~s}, 1 \mathrm{H})) ; \mathrm{m} / \mathrm{z}(\mathrm{ESI}) 315[\mathrm{M}+\mathrm{H}]^{+}$.

\section{7-[(1S)-1-Aminoethyl]-6-bromo-3-methyl-5H-[1,3] thiazolo[3,2-a]pyridin-5-one (9)}

\section{a) From compound 8 .}

A 5 L 4-necked round-bottom was charged with a solution of 7-[(1S)-1-azidoethyl]-6bromo-3-methyl-5H-[1,3]thiazolo[3,2-a]pyridin-5-one in dichloromethane $(3000 \mathrm{~mL}$, previous step) and triphenylphosphine $(87.5 \mathrm{~g}, 334 \mathrm{mmol})$. The resulting solution was heated to $50^{\circ} \mathrm{C}$ for $3 \mathrm{~h}$, allowed to cool and concentrated. The residue was dissolved in THF $(800 \mathrm{~mL})$ and water $(400 \mathrm{~mL})$ and the resulting solution was heated overnight at $50{ }^{\circ} \mathrm{C}$ 
and then allowed to cool. The mixture was concentrated and the residue was chromatographed (silica gel; methanol/dichloromethane $(1: 100$ to $1: 20))$ to give the title compound ( $52 \mathrm{~g}, 60 \%)$ as a yellow solid.

${ }^{1} \mathrm{H}-\mathrm{NMR}\left(300 \mathrm{MHz}, \mathrm{CD}_{3} \mathrm{OD}\right) \delta 1.31(3 \mathrm{H}, \mathrm{d} J=6.6 \mathrm{~Hz}), 2.78(3 \mathrm{H}, \mathrm{s}), 4.40(1 \mathrm{H}, \mathrm{q} J=6.6$ Hz), $6.84(1 \mathrm{H}, \mathrm{s}), \delta 7.05(1 \mathrm{H}, \mathrm{s})) ; \mathrm{m} / \mathrm{z}(\mathrm{ESI}) 287[\mathrm{M}+\mathrm{H}]^{+}$.

\section{b) from compound 10}

(S)-Benzyl (1-(6-bromo-3-methyl-5-oxo-5H-thiazolo[3,2-a]pyridin-7-yl)ethyl)carbamate (10, $10 \mathrm{~g}, 23.7 \mathrm{mmol})$ was dissolved in $\mathrm{CH}_{2} \mathrm{Cl}_{2}(200 \mathrm{~mL})$ and cooled to $0^{\circ} \mathrm{C}$. Boron tribromide (59.5 g, $237 \mathrm{mmol})$ was added dropwise over a period of 15 minutes. The resulting mixture was stirred at RT for 3 hours. The reaction mixture was poured onto ice $(150 \mathrm{~mL})$ and extracted with $\mathrm{CH}_{2} \mathrm{Cl}_{2}(3 \times 100 \mathrm{~mL})$. The aqueous layer was adjusted to $\mathrm{pH}=$ 9 with saturated sodium carbonate and was extracted with $\mathrm{CH}_{2} \mathrm{Cl}_{2}(3 \times 25 \mathrm{~mL})$. The solvent was removed under reduced pressure and the residue was dried under vacuum to give the title compound $(5.50 \mathrm{~g}, 81 \%)$ as a yellow solid.

\footnotetext{
${ }^{1} \mathrm{H}$ NMR (500 MHz, DMSO) $\delta 1.19(\mathrm{~d}, J=6.6 \mathrm{~Hz}, 3 \mathrm{H}), 2.00(\mathrm{~s}, 2 \mathrm{H}), 2.71(\mathrm{~s}, 3 \mathrm{H}), 4.23$ (q, $J=6.6 \mathrm{~Hz}, 1 \mathrm{H}), 7.02(\mathrm{~s}, 1 \mathrm{H}),{ }^{13} \mathrm{C}$ NMR (126 MHz, DMSO) $\delta 17.99,22.99$, 50.64, 97.30, 97.86, 104.08, 108.93, 137.44, 148.75, 157.18); m/z (ESI) $287[\mathrm{M}+\mathrm{H}]^{+}$.
}

\section{Benzyl \\ [(1S)-1-(6-bromo-3-methyl-5-oxo-5H-[1,3]thiazolo[3,2-a]pyridin-7-}

\section{yl)ethyl]carbamate (10)}

A 3 L 4-necked round-bottom flask was charged with 7-[(1S)-1-aminoethyl]-6-bromo-3methyl-5H-[1,3]thiazolo[3,2-a]pyridin-5-one $(9,52 \mathrm{~g}, 181 \mathrm{mmol})$ in $\mathrm{THF} / \mathrm{H}_{2} \mathrm{O}(10: 1,1.1 \mathrm{~L})$ and potassium carbonate $(62.6 \mathrm{~g}, 453 \mathrm{mmol})$ and cooled to $0{ }^{\circ} \mathrm{C}$. $\mathrm{Cbz}-\mathrm{Cl}(46.4 \mathrm{~g}, 272 \mathrm{mmol})$ was added dropwise and the resulting mixture was stirred overnight at room temperature. Water $(3 \mathrm{~L})$ was added, the solids were collected by filtration, washed with water $(5 \times 200$ $\mathrm{mL})$ and then with THF/Hexane $(1: 2)(3 \times 200 \mathrm{~mL})$. The crude product was purified by 
preparative-SFC (CHIRALPAK IC SFC, $5 \times 25 \mathrm{~cm}, 5 \mu \mathrm{m}$; mobile phase $\mathrm{A} \mathrm{CO}_{2}(50 \%)$, B methanol : $\mathrm{CH}_{2} \mathrm{Cl}_{2}=2: 1(0.2 \%$ diethylamine)(50\%); detection, UV $220 \mathrm{~nm})$ to give the title compound (23.5 g, 31\%) as a light yellow solid.

${ }^{1} \mathrm{H}$ NMR (300 MHz, CD 3 OD) $\delta 1.17(\mathrm{~d}, J=7.0 \mathrm{~Hz}, 3 \mathrm{H}), 2.80(\mathrm{~s}, 3 \mathrm{H}), 4.58(\mathrm{~s}, 1 \mathrm{H}), 5.04$ (s, 2H), $6.83(\mathrm{~s}, 1 \mathrm{H}), 6.94(\mathrm{~s}, 1 \mathrm{H}), 7.11-7.51(\mathrm{~m}, 5 \mathrm{H}) ; \mathrm{m} / \mathrm{z}(\mathrm{ESI}) 421[\mathrm{M}+\mathrm{H}]^{+} ; \alpha_{\mathrm{D}}-60.5^{\circ}(\mathrm{c}=$ $5.30 \mathrm{~g} / \mathrm{L} \mathrm{CH}_{2} \mathrm{Cl}_{2}, 21-7^{\circ} \mathrm{C}$ ); SFC Chiralpak IC-3 $5.0 \mu \mathrm{m} ; 100 \times 4.6 \mathrm{~mm}$; Mobile phase A: $\mathrm{CO}_{2}$ B:methanol/0.1\% diethylamine $T_{\mathrm{r}} 1.47 \mathrm{~min}$; e.r $97.7: 2.3$ (minor isomer $T_{\mathrm{r}} 1.14 \mathrm{~min}$ )

\section{Benzyl (1-(3-methyl-5-oxo-6-phenyl-5H-thiazolo[3,2-a]pyridin-7-yl)ethyl)carbamate}

$\mathrm{Cs}_{2} \mathrm{CO}_{3}$ (1083 mg, $3.32 \mathrm{mmol}$ ), phenylboronic acid (152 mg, $\left.1.25 \mathrm{mmol}\right), \mathrm{PdCl}_{2}(\mathrm{dppf})-$ $\mathrm{CH}_{2} \mathrm{Cl}_{2}$ adduct $(68 \mathrm{mg}, 0.08 \mathrm{mmol})$ and $( \pm)$ benzyl (1-(6-bromo-3-methyl-5-oxo-5Hthiazolo[3,2-a]pyridin-7-yl)ethyl)carbamate $(\mathbf{1 0}, 350 \mathrm{mg}, 0.83 \mathrm{mmol})$ were slurried in DME $(10 \mathrm{~mL})$ and water $(2 \mathrm{~mL})$ and heated to $100^{\circ} \mathrm{C}$ for 30 minutes in a microwave. The solvent was evaporated and the crude product was purified by flash chromatography (silica; 80 to $20 \%$ petroleum ether in EtOAc) to give the title compound (236 mg, $68 \%$ ) as a yellow solid.

${ }^{1} \mathrm{H}$ NMR (300 MHz, CD $\left.\mathrm{OD}\right) \delta 1.17$ (d, J=7.0 Hz, 3H), 2.80 (s, 3H), 4.58 (s, 1H), 5.04 (s, 2H), $6.83(\mathrm{~s}, 1 \mathrm{H}), 6.94(\mathrm{~s}, 1 \mathrm{H}), 7.11-7.51(\mathrm{~m}, 11 \mathrm{H}) ; \mathrm{m} / \mathrm{z}(\mathrm{ESI}) 419[\mathrm{M}+\mathrm{H}]^{+}$.

\section{7-(1-Aminoethyl)-3-methyl-6-phenyl-5H-thiazolo[3,2-a]pyridin-5-one (12)}

To a solution of benzyl N-(1-[3-methyl-5-oxo-6-phenyl-5H-[1,3]thiazolo[3,2-a]pyridin-7yl]ethyl carbamate $(\mathbf{1 1}, 240 \mathrm{mg}, 0.57 \mathrm{mmol})$ in dichloromethane $(6 \mathrm{~mL})$ at $0{ }^{\circ} \mathrm{C}$, was added boron tribromide (863 mg, $3.44 \mathrm{mmol}, 6 \mathrm{eq}$ ) dropwise. The resulting solution was stirred for $20 \mathrm{~h}$ at room temperature and then cooled to $0{ }^{\circ} \mathrm{C}$. The reaction was quenched by the addition of water/ice, the $\mathrm{pH}$ was adjusted to 8 with sodium carbonate (aq.), and the mixture was extracted with chloroform. The organic layers were combined, dried over anhydrous sodium sulfate, and concentrated to give the title compound (120 mg, 74\%) as a light yellow solid. 
${ }^{1} \mathrm{H}$ NMR (400 MHz, DMSO) $\delta 1.05$ (d, $\left.J=6.5 \mathrm{~Hz}, 3 \mathrm{H}\right), 1.93$ (s, 2H), 2.68 (s, 3H), 3.68 (q, $J=6.6,1 \mathrm{H}), 6.91(\mathrm{~s}, 1 \mathrm{H}), 7.09(\mathrm{~s}, 1 \mathrm{H}), 7.20(\mathrm{~d}, J=6.0 \mathrm{~Hz}, 2 \mathrm{H}), 7.30(\mathrm{t}, J=7.3 \mathrm{~Hz}, 1 \mathrm{H}), 7.39$ $(\mathrm{t}, J=7.4, \mathrm{~Hz}, 2 \mathrm{H}), 7.50-7.67(\mathrm{~m}, 1 \mathrm{H}) ; \mathrm{m} / \mathrm{z}(\mathrm{ESI}) 285[\mathrm{M}+\mathrm{H}]^{+}$.

\section{(S)-4-Amino-6-[(1-[3-methyl-5-oxo-6-phenyl-5H-[1,3]thiazolo[3,2-a]pyridin-7-}

\section{yl]ethyl)amino]pyrimidine-5-carbonitrile (13)}

7-(1-Aminoethyl)-3-methyl-6-phenyl-5H-[1,3]thiazolo[3,2-a]pyridin-5-one $\quad(12,268 \mathrm{mg}$, $0.94 \mathrm{mmol})$ and 4-amino-6-chloropyrimidine-5-carbonitrile ${ }^{31}$ (145 $\mathrm{mg}, 0.94 \mathrm{mmol}$ ) were dissolved in n-butanol (12 mL). DIEA (1.21 g, $9.36 \mathrm{mmol})$ was added and the resulting solution was heated to $120^{\circ} \mathrm{C}$ for $2 \mathrm{~h}$, allowed to cool and then concentrated. Recrystallisation (ethyl acetate) gave the title compound (130 mg, 34\%) as a light yellow solid. The enantiomers were separated by chiral HPLC (Reprosil NR column $250 \times 20 \mathrm{~mm}$ eluting with heptane : EtOAc : TEA (40:60:0.1)) collecting the first eluting peak which was then further purified by preparative SFC (Phenomenex Luna Hilic $250 \times 30 \mathrm{~mm}$ eluting with $20 \mathrm{mM}$ ammonia in methanol) to give the title compound (16 mg).

${ }^{1} \mathrm{H}$ NMR (500 MHz, DMSO-d6) $\delta 1.23$ (d, $\left.J=7.1 \mathrm{~Hz}, 3 \mathrm{H}\right), 2.67(\mathrm{~d}, J=1.2 \mathrm{~Hz}, 3 \mathrm{H}), 4.91$ (quint, $J=7.0 \mathrm{~Hz}, 1 \mathrm{H}), 6.91-6.94(\mathrm{~m}, 1 \mathrm{H}), 6.97(\mathrm{~s}, 1 \mathrm{H}), 7.05-7.60(\mathrm{~m}, 5 \mathrm{H}), 7.22(\mathrm{brs}, 2 \mathrm{H})$, $7.48(\mathrm{~d}, J=7.0 \mathrm{~Hz}, 1 \mathrm{H}), 7.95(\mathrm{~s}, 1 \mathrm{H}) ;{ }^{13} \mathrm{C}$ NMR (126 MHz, DMSO-d6) $\delta 18.09,20.54$, 47.72, 67.92, 96.08, 107.52, 115.41, 120.28, 126.76, 127.78 (2C), $130.71(2 \mathrm{C}), 136.00$ 137.51, 148.16, 152.48, 159.43, 160.88, 161.57, 164.33; m/z (ESI) $403[\mathrm{M}+\mathrm{H}]^{+} ; \mathrm{HRMS}$ calculated for $\mathrm{C}_{21} \mathrm{H}_{18} \mathrm{~N}_{6} \mathrm{OS}[(\mathrm{M}+\mathrm{H})+]$, 403.1341; found, 403.1345 .

\section{(S)-4-Amino-6-((1-(6-bromo-3-methyl-5-oxo-5H-thiazolo[3,2-a]pyridin-7-}

\section{yl)ethyl)amino)pyrimidine-5-carbonitrile (14)}

(S)-7-(1-Aminoethyl)-6-bromo-3-methyl-5H-thiazolo[3,2-a]pyridin-5-one (9, 1.5 g, 5.2 mmol) and 4-amino-6-chloropyrimidine-5-carbonitrile (0.888 g, $5.75 \mathrm{mmol})$ were dissolved in n-butanol $(20 \mathrm{~mL})$. DIEA $(9.12 \mathrm{~mL}, 52.23 \mathrm{mmol})$ was added and the resulting solution 
was stirred at $120^{\circ} \mathrm{C}$ for 12 hours. The solvent was evaporated, the reaction mixture was diluted with EtOAc, and the residual solid was collected to give the title compound $(1.50 \mathrm{~g}$, $71 \%)$ as a yellow solid.

${ }^{1} \mathrm{H}$ NMR (500 MHz, DMSO-d6) $\delta 1.44(\mathrm{~d}, J=7.1 \mathrm{~Hz}, 3 \mathrm{H}), 2.72(\mathrm{~d}, J=1.0 \mathrm{~Hz}, 3 \mathrm{H}), 5.38$ (quint, $J=7.1 \mathrm{~Hz}, 1 \mathrm{H}), 6.92(\mathrm{~s}, 1 \mathrm{H}), 7.02$ (d, $J=1.2 \mathrm{~Hz}, 1 \mathrm{H}), 7.28$ (brs, 2H), 7.72 (d, $J=7.1$ $\mathrm{Hz}, 1 \mathrm{H}), 7.93$ (s, 1H); ${ }^{13} \mathrm{C}$ NMR (126 MHz, DMSO-d6) $\delta$ 18.0, 19.4, 50.6, 68.3, 96.7, 104.2, $109.1,115.3,137.6,149.0,153.9,157.3,159.6,161.7,164.3 ; \mathrm{m} / \mathrm{z}(\mathrm{ESI}) 405[\mathrm{M}+\mathrm{H}]^{+} \cdot[\mathrm{M}+\mathrm{H}]+$ $=405$.

\section{(S)-4-Amino-6-((1-(6-(3-(aminomethyl)phenyl)-3-methyl-5-oxo-5H-thiazolo[3,2-} a]pyridin-7-yl)ethyl)amino)pyrimidine-5-carbonitrile (15a)

(S)-4-amino-6-((1-(6-bromo-3-methyl-5-oxo-5H-thiazolo[3,2-a]pyridin-7-

yl)ethyl)amino)pyrimidine-5-carbonitrile $(\mathbf{1 4}, 80 \mathrm{mg}, 0.20 \mathrm{mmol})$ was added to a solution of (3-(((tert-butoxycarbonyl)amino)methyl)phenyl)boronic acid (198 mg, $0.79 \mathrm{mmol})$, cesium carbonate $(257 \mathrm{mg}, 0.79 \mathrm{mmol})$ and $\mathrm{PdCl}_{2}(\mathrm{dppf})-\mathrm{CH}_{2} \mathrm{Cl}_{2}$ adduct $(16 \mathrm{mg}, 0.02 \mathrm{mmol})$ in $\mathrm{DME}$ $(2.5 \mathrm{~mL})$ and water $(1 \mathrm{ml})$ at $25^{\circ} \mathrm{C}$ over a period of 10 minutes under nitrogen. The reaction was heated to $100^{\circ} \mathrm{C}$ for 45 minutes in a microwave reactor and then cooled to RT. The solvent was evaporated and the residue was purified by flash silica chromatography, elution gradient 60 to $40 \%$ petroleum ether in EtOAc to give the (S)-tert-butyl 3-(7-(1-((6-amino-5cyanopyrimidin-4-yl)amino)ethyl)-3-methyl-5-oxo-5H-thiazolo[3,2-a]pyridin-6yl)benzylcarbamate (90 mg, $86 \%$ ) as a yellow solid.

TFA (2 mL, $25.96 \mathrm{mmol})$ was added to (S)-tert-butyl 3-(7-(1-((6-amino-5-cyanopyrimidin4-yl)amino)ethyl)-3-methyl-5-oxo-5H-thiazolo[3,2-a]pyridin-6-yl)benzylcarbamate $(80 \mathrm{mg}$, $0.15 \mathrm{mmol})$ in $\mathrm{CH}_{2} \mathrm{Cl}_{2}(4 \mathrm{~mL})$ under nitrogen. The resulting solution was stirred at room temperature for 16 hours. The solvent was evaporated and the residue was purified by preparative HPLC with the following conditions: Column: $\mathrm{X}$ Bridge $\mathrm{C}_{18}, 19 \times 150 \mathrm{~mm}, 5 \mathrm{um}$; 
Mobile Phase A:Water $/ 0.05 \%$ TFA, Mobile Phase B: MeCN; Flow rate: $20 \mathrm{~mL} / \mathrm{min}$; Gradient: $30 \% \mathrm{~B}$ to $70 \% \mathrm{~B}$ in $10 \mathrm{~min} ; 254 \mathrm{~nm}$ to give the title compound (60 $\mathrm{mg}, 73 \%$ ) as a yellow solid.

${ }^{1} \mathrm{H}$ NMR (300 MHz, CD 3 OD) $\delta$ 1.30-1.45 (m, 3H), 2.82 (s, 3H), 4.17 (s, 2H), 5.13-5.23 (m, 1H), $6.86-6.93(\mathrm{~m}, 1 \mathrm{H}), 7.05(\mathrm{~s}, 1 \mathrm{H}), 7.36(\mathrm{~s}, 1 \mathrm{H}), 7.45(\mathrm{~d}, J=7.6 \mathrm{~Hz}, 1 \mathrm{H}), 7.54(\mathrm{t}, J=7.5$ $\mathrm{Hz}, 1 \mathrm{H}), 7.66$ (s, 1H), 8.00-8.25 (m, 1H); m/z (ESI) $432[\mathrm{M}+\mathrm{H}]^{+}$.

General procedure for synthesis of compounds $15 \mathrm{~b}-\mathrm{g}, 20 \mathrm{a}-\mathrm{g}$ :

Aldehyde 16 (65 mg, $0.15 \mathrm{mmol})$ was dissolved in a mixture of methanol and dichloromethane $(1: 1,10 \mathrm{~mL})$ and the solution was cooled in ice. Sodium cyanoborohydride (14 mg, 1.5 eq) and acetic acid (43 $\mu \mathrm{L}, 5$ eq) were added followed by the amine (neat or as a solution; $1 \mathrm{eq}$ ) over a period of $15 \mathrm{~min}$. The mixture was allowed to stir overnight at ambient temperature then water $(0.5 \mathrm{~mL})$ was added and the mixture was concentrated. The residue was purified by preparative HPLC (Waters XBridge Prep $\mathrm{C}_{18}$ OBD or Phenyl OBD column, $5 \mu$ silica, $19 \mathrm{~mm}$ diameter, $150 \mathrm{~mm}$ length), using decreasingly polar mixtures of water (containing $10 \% \mathrm{NH}_{4} \mathrm{HCO}_{3}$ ) and $\mathrm{MeCN}$ as eluents to give the pure products.

(S)-4-Amino-6-((1-(3-methyl-6-(3-((methylamino)methyl)phenyl)-5-oxo-5Hthiazolo[3,2-a]pyridin-7-yl)ethyl)amino)pyrimidine-5-carbonitrile (15b)

${ }^{1} \mathrm{H}$ NMR (300 MHz, CD $\left.\mathrm{OD}\right) \delta 1.27-1.43(\mathrm{~m}, 3 \mathrm{H}), 2.76(\mathrm{~s}, 3 \mathrm{H}), 2.81(\mathrm{~d}, J=1.1 \mathrm{~Hz}, 3 \mathrm{H})$, $4.16-4.29(\mathrm{~m}, 2 \mathrm{H}), 4.98-5.14(\mathrm{~m}, 1 \mathrm{H}), 6.87(\mathrm{~d}, J=1.2 \mathrm{~Hz}, 1 \mathrm{H}), 7.05(\mathrm{~s}, 1 \mathrm{H}), 7.33-7.78$ (m, 4H), $7.96(\mathrm{~s}, 1 \mathrm{H}) ; \mathrm{m} / \mathrm{z}(\mathrm{ESI}) 446[\mathrm{M}+\mathrm{H}]^{+}$.

(S)-4-Amino-6-((1-(6-(3-((dimethylamino)methyl)phenyl)-3-methyl-5-oxo-5Hthiazolo[3,2-a]pyridin-7-yl)ethyl)amino)pyrimidine-5-carbonitrile (15c)

${ }^{1} \mathrm{H}$ NMR (300 MHz, DMSO) $\delta 1.24(\mathrm{~d}, J=7.0 \mathrm{~Hz}, 3 \mathrm{H}), 2.35(\mathrm{~s}, 6 \mathrm{H}), 2.68$ (d, $J=1.2 \mathrm{~Hz}$, 3H), $3.71(\mathrm{~s}, 2 \mathrm{H}), 4.89(\mathrm{~s}, 1 \mathrm{H}), 6.94(\mathrm{~d}, J=1.3 \mathrm{~Hz}, 1 \mathrm{H}), 7.00(\mathrm{~s}, 1 \mathrm{H}), 7.1-7.34(\mathrm{~m}, 4 \mathrm{H}), 7.36$ $-7.44(\mathrm{~m}, 1 \mathrm{H}), 7.52(\mathrm{~d}, J=7.2 \mathrm{~Hz}, 1 \mathrm{H}), 7.95(\mathrm{~s}, 1 \mathrm{H}), 8.14(\mathrm{~s}, 1 \mathrm{H}) ; \mathrm{m} / \mathrm{z}(\mathrm{ESI}) 460[\mathrm{M}+\mathrm{H}]^{+}$. 
(S)-4-Amino-6-((1-(6-(3-(((2-methoxyethyl)amino)methyl)phenyl)-3-methyl-5-oxo-5Hthiazolo[3,2-a]pyridin-7-yl)ethyl)amino)pyrimidine-5-carbonitrile (15d)

${ }^{1} \mathrm{H}$ NMR (300 MHz, CD 3 OD) $\delta 1.32(\mathrm{~d}, J=6.9 \mathrm{~Hz}, 3 \mathrm{H}), 2.79(\mathrm{~d}, J=1.1 \mathrm{~Hz}, 5 \mathrm{H}), 3.48$ (s, 2H), $3.84(\mathrm{~s}, 2 \mathrm{H}), 5.10(\mathrm{~d}, J=7.1 \mathrm{~Hz}, 1 \mathrm{H}), 6.82(\mathrm{~d}, J=1.2 \mathrm{~Hz}, 1 \mathrm{H}), 7.01(\mathrm{~s}, 1 \mathrm{H}), 7.22(\mathrm{~m}$, 1H), $7.34(\mathrm{~d}, J=7.5 \mathrm{~Hz}, 1 \mathrm{H}), 7.43(\mathrm{t}, J=7.5 \mathrm{~Hz}, 1 \mathrm{H}), 7.55(\mathrm{~m}, 1 \mathrm{H}), 7.96-8.01(\mathrm{~m}, 1 \mathrm{H})(3 \mathrm{H}$ obscured); m/z (ESI) $490[\mathrm{M}+\mathrm{H}]^{+}$.

(S)-4-Amino-6-((1-(6-(3-((isobutyl(methyl)amino)methyl)phenyl)-3-methyl-5-oxothiazolo(3,2-a)pyridin-7-yl)ethyl)amino)pyrimidine-5-carbonitrile (15e)

${ }^{1} \mathrm{H}$ NMR (300 MHz, DMSO) $\delta 0.82(\mathrm{~d}, J=6.4 \mathrm{~Hz}, 6 \mathrm{H}), 1.22(\mathrm{~d}, J=7.0 \mathrm{~Hz}, 3 \mathrm{H}), 1.76(\mathrm{~s}$, 1H), $2.07(\mathrm{~s}, 5 \mathrm{H}), 2.67(\mathrm{~s}, 3 \mathrm{H}), 3.43(\mathrm{~s}, 2 \mathrm{H}), 4.84-5.01(\mathrm{~m}, 1 \mathrm{H}), 6.92(\mathrm{~s}, 1 \mathrm{H}), 6.97(\mathrm{~s}, 1 \mathrm{H})$, $7.23(\mathrm{~s}, 3 \mathrm{H}), 7.33(\mathrm{~s}, 2 \mathrm{H}), 7.48(\mathrm{~d}, J=6.9 \mathrm{~Hz}, 1 \mathrm{H}), 7.93(\mathrm{~s}, 1 \mathrm{H}) ; \mathrm{m} / \mathrm{z}(\mathrm{ESI}) 502[\mathrm{M}+\mathrm{H}]^{+}$.

(S)-4-Amino-6-((1-(6-(3-(azetidin-1-ylmethyl)phenyl)-3-methyl-5-oxo-5H-thiazolo[3,2a]pyridin-7-yl)ethyl)amino)pyrimidine-5-carbonitrile (15f)

${ }^{1} \mathrm{H}$ NMR $\left(300 \mathrm{MHz}, \mathrm{CD}_{3} \mathrm{OD}\right) \delta 1.33(\mathrm{~d}, J=7.1 \mathrm{~Hz}, 3 \mathrm{H}), 2.22(\mathrm{~s}, 2 \mathrm{H}), 2.68-2.9(\mathrm{~m}, 3 \mathrm{H})$, $3.54(\mathrm{~s}, 4 \mathrm{H}), 3.85(\mathrm{~s}, 2 \mathrm{H}), 5.06(\mathrm{~s}, 1 \mathrm{H}), 6.83(\mathrm{~d}, J=1.1 \mathrm{~Hz}, 1 \mathrm{H}), 7.01(\mathrm{~s}, 1 \mathrm{H}), 7.25(\mathrm{~s}, 1 \mathrm{H})$, $7.33(\mathrm{~d}, J=7.6 \mathrm{~Hz}, 1 \mathrm{H}), 7.45(\mathrm{t}, J=7.6 \mathrm{~Hz}, 1 \mathrm{H}), 7.56(\mathrm{~s}, 1 \mathrm{H}), 7.96-8.02(\mathrm{~m}, 1 \mathrm{H}) ; \mathrm{m} / \mathrm{z}(\mathrm{ESI})$ $472[\mathrm{M}+\mathrm{H}]^{+}$.

(S)-4-Amino-6-((1-(3-methyl-5-oxo-6-(3-(((4-phenethoxybutyl)amino)methyl)phenyl)5H-thiazolo[3,2-a]pyridin-7-yl)ethyl)amino)pyrimidine-5-carbonitrile (15g)

${ }^{1} \mathrm{H}$ NMR (400MHz; $\left.\mathrm{CD}_{3} \mathrm{OD}\right) \delta$ 1.28-1.42 (3H, m), 1.67-1.79 (4H, d), 2.67-2.86 (5H,m), 2.98-3.09 (2H, m), 3.50-3.51 (2H, m), 3.67.(2H, s), 4.17-4.19 (2H,d), 3.57 (2H,s), 5.00-5.20 $(1 \mathrm{H}, \mathrm{m}), 6.89(1 \mathrm{H}, \mathrm{s}), 7.06(1 \mathrm{H}, \mathrm{s}), 7.15-7.28(5 \mathrm{H}, \mathrm{m}), 7.44-7.46(2 \mathrm{H}, \mathrm{d}), 7.50-7.75(2 \mathrm{H}, \mathrm{m})$, $8.00(1 \mathrm{H}, \mathrm{s}) ; \mathrm{m} / \mathrm{z}(\mathrm{ESI}) 608[\mathrm{M}+\mathrm{H}]^{+}$.

(S)-4-Amino-6-((1-(6-(3-formylphenyl)-3-methyl-5-oxo-5H-thiazolo[3,2-a]pyridin-7yl)ethyl)amino)pyrimidine-5-carbonitrile (16) 
(3-Formylphenyl)boronic acid (370 mg, $2.47 \mathrm{mmol})$ was added to (S)-4-amino-6-((1-(6bromo-3-methyl-5-oxo-5H-thiazolo[3,2-a]pyridin-7-yl)ethyl)amino)pyrimidine-5-carbonitrile (14, $500 \mathrm{mg}, 1.23 \mathrm{mmol})$, cesium carbonate (804 mg, $2.47 \mathrm{mmol})$ and $\mathrm{PdCl}_{2}(\mathrm{dppf})-\mathrm{CH}_{2} \mathrm{Cl}_{2}$ adduct $(101 \mathrm{mg}, 0.12 \mathrm{mmol})$ in DME $(10 \mathrm{~mL})$ and water $(3 \mathrm{ml})$ at $25^{\circ} \mathrm{C}$ over a period of 15 minutes under nitrogen. The reaction was heated to $100{ }^{\circ} \mathrm{C}$ for 30 minutes in a microwave reactor and cooled to RT. The reaction mixture was quenched with water $(10 \mathrm{~mL})$, extracted with EtOAc $(3 \times 10 \mathrm{~mL})$, the organic layer was dried over $\mathrm{Na}_{2} \mathrm{SO}_{4}$, filtered and evaporated. The crude product was purified by flash silica chromatography, elution gradient 30 to $50 \%$ EtOAc in petroleum ether to give the title compound (400 mg, $75 \%$ ) as a white solid.

${ }^{1} \mathrm{H}$ NMR (500 MHz, DMSO-d6) $\delta 1.26(\mathrm{~d}, J=7.1 \mathrm{~Hz}, 3 \mathrm{H}), 2.68(\mathrm{~d}, J=1.1 \mathrm{~Hz}, 3 \mathrm{H}), 4.86$ (quint, $J=7.0 \mathrm{~Hz}, 1 \mathrm{H}), 6.96(\mathrm{~d}, J=1.3 \mathrm{~Hz}, 1 \mathrm{H}), 7.05(\mathrm{~s}, 1 \mathrm{H}), 7.23$ (brs, 2H), 7.56 (d, $J=7.1$ $\mathrm{Hz}, 1 \mathrm{H}), 7.61-7.67(\mathrm{~m}, 1 \mathrm{H}), 7.84-7.88(\mathrm{~m}, 1 \mathrm{H}), 7.94(\mathrm{~s}, 1 \mathrm{H}), 7.4-8.2$ (vbrm, 2H), 10.05 $(\mathrm{s}, 1 \mathrm{H})$. Note: aromatic protons 2 and 6 from the 3-formylphenyl ring are observed as very broad signals in baseline between 7.4-8.2 ppm; ${ }^{13} \mathrm{C}$ NMR (126 MHz, DMSO) $\delta 18.0,20.5$, $47.7,67.9,96.4,107.8,115.4,118.9,128.0,128.7,132.2,136.0,137.0,137.1,137.6,152.6$, $159.4,160.7,161.5,164.3,193.2 ; \mathrm{m} / \mathrm{z}(\mathrm{ESI}) 431[\mathrm{M}+\mathrm{H}]^{+}$.

\section{(S)-4-Amino-6-((1-(6-(3-(2-(dimethylamino)ethyl)phenyl)-3-methyl-5-oxo-5H-}

\section{thiazolo[3,2-a]pyridin-7-yl)ethyl)amino)pyrimidine-5-carbonitrile formic acid salt (17)}

\section{Step 1}

3rd Generation $\mathrm{PCy}_{3}$ precatalyst ${ }^{32}$ (48 mg, 0.07 mmol), (S)-4-amino-6-((1-(6-bromo-3methyl-5-oxo-5H-thiazolo[3,2-a]pyridin-7-yl)ethyl)amino)pyrimidine-5-carbonitrile (300 mg, $0.74 \mathrm{mmol})$, tert-butyl 3-(4,4,5,5-tetramethyl-1,3,2-dioxaborolan-2-yl)phenethylcarbamate (514 mg, $1.48 \mathrm{mmol}$ potassium phosphate (471 mg, $2.22 \mathrm{mmol}$ ) and $\mathrm{Cy}_{3} \mathrm{P} . \mathrm{HBF}_{4}(54.5 \mathrm{mg}$, $0.15 \mathrm{mmol})$ were mixed in dioxane $(12 \mathrm{~mL}) /$ water $(3 \mathrm{~mL})$ and sealed into a microwave tube. The reaction was heated to $130^{\circ} \mathrm{C}$ for 1 hour in the microwave reactor and cooled to RT. The 
reaction mixture was diluted with $\mathrm{CH}_{2} \mathrm{Cl}_{2}(150 \mathrm{~mL})$, and washed with water $(100 \mathrm{~mL} \times 1)$, and saturated brine $(100 \mathrm{~mL} \times 1)$. The organic layer was dried over $\mathrm{Na}_{2} \mathrm{SO}_{4}$, filtered and evaporated. The residue was purified by flash silica chromatography, elution gradient 20 to $50 \%$ EtOAc in petroleum ether to give (S)-tert-butyl 3-(7-(1-((6-amino-5-cyanopyrimidin-4yl)amino)ethyl)-3-methyl-5-oxo-5H-thiazolo[3,2-a]pyridin-6-yl)phenethylcarbamate (180 mg, $45 \%)$ as a yellow solid.

\section{Step 2}

TFA (2.5 mL, $33 \mathrm{mmol})$ was added to (S)-tert-butyl 3-(7-(1-((6-amino-5-cyanopyrimidin-4yl)amino)ethyl)-3-methyl-5-oxo-5H-thiazolo[3,2-a]pyridin-6-yl)phenethylcarbamate (180 mg, $0.33 \mathrm{mmol})$ in $\mathrm{CH}_{2} \mathrm{Cl}_{2}(5 \mathrm{~mL})$ at $25^{\circ} \mathrm{C}$ under nitrogen. The resulting mixture was stirred at $25^{\circ} \mathrm{C}$ for $4 \mathrm{~h}$. The solvent was removed under reduced pressure and the crude product was

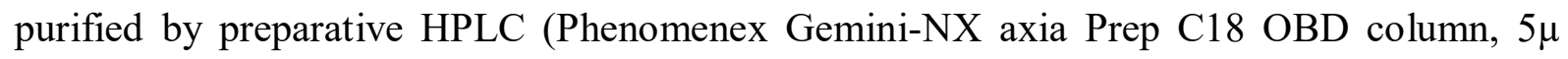
silica, $19 \mathrm{~mm}$ diameter, $100 \mathrm{~mm}$ length), using water (containing $1 \% \mathrm{TFA}$ ) and $\mathrm{MeCN}$ as eluents to give (S)-4-amino-6-((1-(6-(3-(2-aminoethyl)phenyl)-3-methyl-5-oxo-5Hthiazolo[3,2-a]pyridin-7-yl)ethyl)amino)pyrimidine-5-carbonitrile (130 $\mathrm{mg}, 70 \%)$ as a pale yellow solid.

${ }^{1} \mathrm{H}$ NMR (300 MHz, CD $\left.\mathrm{OD}\right) \delta 1.32-1.45(\mathrm{~m}, 3 \mathrm{H}), 2.81(\mathrm{~d}, J=0.9 \mathrm{~Hz}, 3 \mathrm{H}), 2.9-3.1(\mathrm{~m}$, 2H), $3.15-3.3(\mathrm{~m}, 2 \mathrm{H}), 5.03-5.21(\mathrm{~m}, 1 \mathrm{H}), 6.88(\mathrm{~s}, 1 \mathrm{H}), 6.99-7.58(\mathrm{~m}, 5 \mathrm{H}), 7.96-8.13$ $(\mathrm{m}, 1 \mathrm{H})$

\section{Step 3}

Sodium cyanoborohydride (11 mg, $0.18 \mathrm{mmol})$ was added to (S)-4-amino-6-((1-(6-(3-(2aminoethyl)phenyl)-3-methyl-5-oxo-5H-thiazolo[3,2-a]pyridin-7-yl)ethyl)amino)pyrimidine5-carbonitrile (40 mg, $0.09 \mathrm{mmol})$, formaldehyde $(20 \mathrm{mg}, 0.27 \mathrm{mmol})$ and $\mathrm{AcOH}(0.026 \mathrm{~mL}$, $0.45 \mathrm{mmol})$ in $\mathrm{MeOH}(5 \mathrm{~mL})$ at $25^{\circ} \mathrm{C}$. The resulting mixture was stirred at $25{ }^{\circ} \mathrm{C}$ for $3 \mathrm{~h}$. The crude product was purified by preparative HPLC (Phenomenex Gemini-NX axia Prep 
C18 OBD column, $5 \mu$ silica, $19 \mathrm{~mm}$ diameter, $100 \mathrm{~mm}$ length), using water (containing 1\% Formic acid) and $\mathrm{MeCN}$ as eluents to give the title compound (9 $\mathrm{mg}, 20 \%$ ) as a pale yellow solid.

$$
\begin{aligned}
& { }^{1} \mathrm{H} \text { NMR }\left(300 \mathrm{MHz}, \mathrm{CD}_{3} \mathrm{OD}\right) \delta 1.26-1.41(\mathrm{~m}, 3 \mathrm{H}), 2.74-2.89(\mathrm{~m}, 9 \mathrm{H}), 2.96-3.11(\mathrm{~m}, \\
& 2 \mathrm{H}), 3.19-3.36(\mathrm{~m}, 2 \mathrm{H}), 4.98-5.16(\mathrm{~m}, 1 \mathrm{H}), 6.84-6.86(\mathrm{~m}, 1 \mathrm{H}), 7.00-7.07(\mathrm{~m}, 1 \mathrm{H}), 7.14 \\
& -7.24(\mathrm{~m}, 1 \mathrm{H}), 7.25-7.34(\mathrm{~m}, 1 \mathrm{H}), 7.38-7.57(\mathrm{~m}, 2 \mathrm{H}), 7.95(\mathrm{~s}, 1 \mathrm{H}), 8.54(\mathrm{~s}, 1 \mathrm{H}) ; \mathrm{m} / \mathrm{z}(\mathrm{ESI}) \\
& 490[\mathrm{M}+\mathrm{H}]^{+} .
\end{aligned}
$$

(S)-4-Amino-6-((1-(6-(3-(2-(dimethylamino)ethoxy)phenyl)-3-methyl-5-oxo-5H-

thiazolo[3,2-a]pyridin-7-yl)ethyl)amino)pyrimidine-5-carbonitrile formic acid salt (18)

\section{Step 1}

$3^{\text {rd }}$ Generation $\mathrm{PCy}_{3}$ precatalyst $^{32}(48.1 \mathrm{mg}, 0.07 \mathrm{mmol}), \mathrm{PCy}_{3} . \mathrm{HBF}_{4}(54.5 \mathrm{mg}, 0.15 \mathrm{mmol})$, (S)-4-amino-6-((1-(6-bromo-3-methyl-5-oxo-5H-thiazolo[3,2-a]pyridin-7-

yl)ethyl)amino)pyrimidine-5-carbonitrile (14, $100 \mathrm{mg}, 0.25 \mathrm{mmol}), 3-(4,4,5,5$-tetramethyl1,3,2-dioxaborolan-2-yl)phenol (163 mg, $0.74 \mathrm{mmol})$ and $\mathrm{K}_{3} \mathrm{PO}_{4}(157 \mathrm{mg}, 0.74 \mathrm{mmol})$ were dissolved in dioxane $(12 \mathrm{~mL}) / \mathrm{H}_{2} \mathrm{O}(2 \mathrm{~mL})$ and sealed into a microwave tube. The reaction was heated to $130^{\circ} \mathrm{C}$ for $1 \mathrm{~h}$. The reaction mixture was diluted with $\mathrm{CH}_{2} \mathrm{Cl}_{2}(200 \mathrm{~mL})$, and washed sequentially with saturated $\mathrm{NaHCO}_{3}(100 \mathrm{~mL})$, water $(100 \mathrm{~mL})$, and saturated brine $(100 \mathrm{~mL})$. The organic layer was dried over $\mathrm{Na}_{2} \mathrm{SO}_{4}$, filtered and evaporated. The crude product was purified by preparative HPLC (Phenomenex Gemini-NX axia Prep $\mathrm{C}_{18}$ OBD column, $5 \mu, 19 \times 100 \mathrm{~mm}$; gradient $\mathrm{MeCN}$ in 1\% aq TFA) to give (S)-4-Amino-6-((1-(6-(3hydroxyphenyl)-3-methyl-5-oxo-5H-thiazolo[3,2-a]pyridin-7-yl)ethyl)amino)pyrimidine-5carbonitrile (80 mg, $61 \%)$ as a yellow solid.

\footnotetext{
${ }^{1} \mathrm{H}$ NMR (400 MHz,CD 3 OD) $\delta 1.40(\mathrm{~d}, J=6.8 \mathrm{~Hz}, 3 \mathrm{H}), 2.79(\mathrm{~s}, 3 \mathrm{H}), 5.22(\mathrm{~s}, 1 \mathrm{H}), 6.76(\mathrm{~s}$, 2H), $6.84(\mathrm{~s}, 1 \mathrm{H}), 6.99(\mathrm{~s}, 2 \mathrm{H}), 7.24(\mathrm{t}, J=7.8,7.8 \mathrm{~Hz}, 1 \mathrm{H}), 8.07(\mathrm{~s}, 1 \mathrm{H})$.
}

\section{Step 2}


DEAD (75 mg, $0.43 \mathrm{mmol})$ was added to (S)-4-amino-6-((1-(6-(3-hydroxyphenyl)-3methyl-5-oxo-5H-thiazolo[3,2-a]pyridin-7-yl)ethyl)amino)pyrimidine-5-carbonitrile (60 mg, $0.14 \mathrm{mmol}), 2$-(dimethylamino)ethanol (19 $\mathrm{mg}, 0.22 \mathrm{mmol})$ and triphenylphosphine $(113 \mathrm{mg}$, $0.43 \mathrm{mmol})$ in THF $(10 \mathrm{~mL})$ at $0{ }^{\circ} \mathrm{C}$ over a period of 2 minutes under nitrogen. The resulting solution was stirred at $40{ }^{\circ} \mathrm{C}$ for 12 hours. The solvent was removed under reduced pressure and the crude product was purified by preparative HPLC (XBridge Prep $\mathrm{C}_{18}$ OBD column, $5 \mu$ silica, $19 \mathrm{~mm}$ diameter, $150 \mathrm{~mm}$ length), using water (containing $0.05 \%$ Formic acid) and $\mathrm{MeCN}$ as eluents to give the title compound (10 mg, $13 \%$ ) as a white solid.

${ }^{1} \mathrm{H}$ NMR (300 MHz, CD $\left.3 \mathrm{OD}\right) \delta 1.34(\mathrm{~d}, J=7.1 \mathrm{~Hz}, 3 \mathrm{H}), 2.58(\mathrm{~s}, 6 \mathrm{H}), 2.80(\mathrm{~s}, 3 \mathrm{H}), 3.03-$ $3.14(\mathrm{~m}, 2 \mathrm{H}), 4.15-4.29(\mathrm{~m}, 2 \mathrm{H}), 5.07-5.19(\mathrm{~m}, 1 \mathrm{H}), 6.8-6.92(\mathrm{~m}, 2 \mathrm{H}), 6.93-6.99(\mathrm{~m}$, 1H), $7.00(\mathrm{~s}, 1 \mathrm{H}), 7.15-7.25(\mathrm{~m}, 1 \mathrm{H}), 7.36(\mathrm{t}, J=7.9 \mathrm{~Hz}, 1 \mathrm{H}), 7.95(\mathrm{~s}, 1 \mathrm{H}), 8.52(\mathrm{~s}, 1 \mathrm{H}) ; \mathrm{m} / \mathrm{z}$ (ESI) $474[\mathrm{M}+\mathrm{H}]^{+}$.

(S)-4-Amino-6-((1-(3-methyl-5-oxo-6-(3-((1-(3,3,3-trifluoropropyl)piperidin-4yl)methyl)phenyl)-5H-thiazolo[3,2-a]pyridin-7-yl)ethyl)amino)pyrimidine-5-carbonitrile (19)

\section{Step 1}

$\mathrm{PdCl}_{2}$ (dppf)- $\mathrm{CH}_{2} \mathrm{Cl}_{2}$ adduct (100 mg, $\left.0.12 \mathrm{mmol}\right)$, (S)-4-amino-6-((1-(6-bromo-3-methyl-5oxo-5H-thiazolo[3,2-a]pyridin-7-yl)ethyl)amino)pyrimidine-5-carbonitrile (14, $250 \mathrm{mg}, 0.62$ mmol), tert-butyl 4-(3-(4,4,5,5-tetramethyl-1,3,2-dioxaborolan-2-yl)benzyl)piperidine-1carboxylate $^{33}$ (990 mg, $2.47 \mathrm{mmol}$ ) and cesium carbonate (804 mg, $2.47 \mathrm{mmol}$ ) were dissolved in dioxane $(12 \mathrm{~mL}) /$ water $(4 \mathrm{~mL})$ and sealed into a microwave tube. The reaction was heated to $130^{\circ} \mathrm{C}$ for 2 hours in a microwave reactor and cooled to RT. The reaction mixture was diluted with EtOAc $(100 \mathrm{~mL})$, and washed sequentially with water $(100 \mathrm{~mL} \times 1)$ and saturated brine $(100 \mathrm{~mL} \times 1)$. The organic layer was dried over $\mathrm{Na}_{2} \mathrm{SO}_{4}$, filtered and evaporated. The residue was purified by preparative TLC (EtOAc: petroleum ether $=1: 1$ ), to 
give tert-butyl 4-[3-(7-\{(1S)-1-[(6-amino-5-cyanopyrimidin-4-yl)amino]ethyl $\}-3-$ methyl-5oxo-5H-[1,3]thiazolo[3,2-a]pyridin-6-yl)benzyl]piperidine-1-carboxylate (260 mg, $70 \%$ ) as a yellow solid.

\section{Step 2}

TFA (1.5 mL, $19 \mathrm{mmol})$ was added to (S)-tert-butyl 4-(3-(7-(1-((6-amino-5cyanopyrimidin-4-yl)amino)ethyl)-3-methyl-5-oxo-5H-thiazolo[3,2-a]pyridin-6-

yl)benzyl)piperidine-1-carboxylate $(260 \mathrm{mg}, 0.43 \mathrm{mmol})$ in $\mathrm{CH}_{2} \mathrm{Cl}_{2}(20 \mathrm{~mL})$ at $0{ }^{\circ} \mathrm{C}$ over a period of 15 minutes under nitrogen. The resulting solution was stirred for 12 hours. The reaction mixture was quenched with saturated $\mathrm{NaHCO}_{3}(20 \mathrm{~mL})$, extracted with $\mathrm{CH}_{2} \mathrm{Cl}_{2}(3 \times$ $10 \mathrm{~mL}$ ), the organic layer was dried over $\mathrm{Na}_{2} \mathrm{SO}_{4}$, filtered and evaporated to give (S)-4amino-6-((1-(3-methyl-5-oxo-6-(3-(piperidin-4-ylmethyl)phenyl)-5H-thiazolo[3,2-a]pyridin7-yl)ethyl)amino)pyrimidine-5-carbonitrile $(230 \mathrm{mg}, 106 \%)$ as a yellow solid that was used without further purification.

\section{Step 3}

$\mathrm{NaCNBH}_{3}$ (15 mg, $\left.0.24 \mathrm{mmol}\right)$ was added to (S)-4-amino-6-((1-(3-methyl-5-oxo-6-(3(piperidin-4-ylmethyl)phenyl)-5H-thiazolo[3,2-a]pyridin-7-yl)ethyl)amino)pyrimidine-5carbonitrile (60 mg, $0.12 \mathrm{mmol}), 3,3,3$-trifluoropropanal $(53.8 \mathrm{mg}, 0.48 \mathrm{mmol})$ and $\mathrm{AcOH}$ $(0.034 \mathrm{~mL}, 0.60 \mathrm{mmol})$ in a mixture of $\mathrm{CH}_{2} \mathrm{Cl}_{2}(5 \mathrm{~mL})$ and $\mathrm{MeOH}(5 \mathrm{~mL})$ were added at $25^{\circ} \mathrm{C}$ over a period of 15 minutes. The resulting mixture was stirred at $45{ }^{\circ} \mathrm{C}$ for 12 hours. The solvent was evaporated and the residue was purified by preparative HPLC (XBridge Prep $\mathrm{C}_{18}$ OBD column, $5 \mu$ silica, $19 \mathrm{~mm}$ diameter, $150 \mathrm{~mm}$ length), using decreasingly polar mixtures of water (containing $0.5 \% \mathrm{TFA}$ ) and $\mathrm{MeCN}$ as eluents to give the title compound (20 mg, $16 \%)$ as a yellow solid.

${ }^{1} \mathrm{H}$ NMR (300 MHz, CD $\left.{ }_{3} \mathrm{OD}\right) \delta 1.27-1.41(\mathrm{~m}, 10 \mathrm{H}), 1.42-1.61(\mathrm{~m}, 2 \mathrm{H}), 1.88-2.08(\mathrm{~m}$, 4H), $2.66(\mathrm{~d}, J=6.6 \mathrm{~Hz}, 2 \mathrm{H}), 2.80(\mathrm{~d}, J=1.0 \mathrm{~Hz}, 3 \mathrm{H}), 2.87-3.06(\mathrm{~m}, 3 \mathrm{H}), 3.36-3.52(\mathrm{~m}$, 
$3 \mathrm{H}), 5.06-5.21(\mathrm{~m}, 1 \mathrm{H}), 6.86(\mathrm{~d}, J=1.2 \mathrm{~Hz}, 1 \mathrm{H}), 7.02(\mathrm{~s}, 1 \mathrm{H}), 7.07-7.22(\mathrm{~m}, 2 \mathrm{H}), 7.33-$ $7.44(\mathrm{~m}, 2 \mathrm{H}), 8.04(\mathrm{~s}, 1 \mathrm{H}) ; \mathrm{m} / \mathrm{z}(\mathrm{ESI}) 596[\mathrm{M}+\mathrm{H}]^{+}$.

Compounds 20a - 20g synthesised following procedure described earlier for $15 \mathrm{~b}-\mathrm{g}$ ((S)-4-Amino-6-((1-(3-methyl-6-(3-(((2-morpholinoethyl)amino)methyl)phenyl)-5-oxo5H-thiazolo[3,2-a]pyridin-7-yl)ethyl)amino)pyrimidine-5-carbonitrile (20a)

${ }^{1} \mathrm{H}$ NMR (300 MHz, DMSO-d6) $\delta 1.22$ (d, $\left.J=7.0 \mathrm{~Hz}, 3 \mathrm{H}\right), 1.94-2.4$ (m, 7H), $2.53-2.62$ $(\mathrm{m}, 2 \mathrm{H}), 2.68(\mathrm{~s}, 3 \mathrm{H}), 3.4-3.56(\mathrm{~m}, 4 \mathrm{H}), 3.72(\mathrm{~s}, 2 \mathrm{H}), 4.85-4.99(\mathrm{~m}, 1 \mathrm{H}), 6.92(\mathrm{~d}, J=1.2$ $\mathrm{Hz}, 1 \mathrm{H}), 6.97(\mathrm{~s}, 1 \mathrm{H}), 7.02-7.61(\mathrm{~m}, 7 \mathrm{H}), 7.97(\mathrm{~s}, 1 \mathrm{H}) ; \mathrm{m} / \mathrm{z}(\mathrm{ESI}) 545[\mathrm{M}+\mathrm{H}]^{+}$.

(S)-4-Amino-6-((1-(6-(3-((4-(dimethylamino)piperidin-1-yl)methyl)phenyl)-3-methyl-5oxo-5H-thiazolo[3,2-a]pyridin-7-yl)ethyl)amino)pyrimidine-5-carbonitrile (20b)

${ }^{1} \mathrm{H}$ NMR (500 MHz, DMSO-d6) $\delta 1.22(\mathrm{~d}, J=7.0 \mathrm{~Hz}, 3 \mathrm{H}), 1.27-1.40(\mathrm{~m}, 2 \mathrm{H}), 1.57$ $1.75(\mathrm{~m}, 2 \mathrm{H}), 1.83-1.98(\mathrm{~m}, 2 \mathrm{H}), 2.00-2.12(\mathrm{~m}, 1 \mathrm{H}), 2.15(\mathrm{~s}, 6 \mathrm{H}), 2.68(\mathrm{~s}, 3 \mathrm{H}), 2.76-2.91$ (m, 2H), $3.44(\mathrm{~s}, 2 \mathrm{H}), 4.84-4.96(\mathrm{~m}, 1 \mathrm{H}), 6.91-6.94(\mathrm{~m}, 1 \mathrm{H}), 6.98(\mathrm{~s}, 1 \mathrm{H}), 7.00-7.47$ (m, 6H), $7.48(\mathrm{~d}, J=7.1 \mathrm{~Hz}, 1 \mathrm{H}), 7.94(\mathrm{~s}, 1 \mathrm{H}) ;{ }^{13} \mathrm{C}$ NMR (126 MHz, DMSO-d6) $\delta 18.14,20.51$, $27.90(2 \mathrm{C}), 41.33(2 \mathrm{C}), 47.72,52.36,52.46,61.68,62.18,67.90,96.23,107.55,115.44$, $120.39,127.19,127.57,129.19,130.99,135.74,137.53,138.11,148.11,152.42,159.40$, 160.87, 161.56, 164.36; m/z (ESI) $543[\mathrm{M}+\mathrm{H}]^{+}$; HRMS calculated for $\mathrm{C}_{29} \mathrm{H}_{35} \mathrm{~N}_{8} \mathrm{OS}[(\mathrm{M}+$ $\mathrm{H})+]$, 543.2649; found, 543.2641

(S)-4-Amino-6-((1-(6-(3-((4-((isobutyl(methyl)amino)methyl)piperidin-1yl)methyl)phenyl)-3-methyl-5-oxo-5H-thiazolo[3,2-a]pyridin-7yl)ethyl)amino)pyrimidine-5-carbonitrile (20c)

${ }^{1} \mathrm{H}$ NMR (400 MHz, CD $\left.3 \mathrm{OD}\right) \delta 0.88(\mathrm{~d}, J=6.0 \mathrm{~Hz}, 6 \mathrm{H}), 1.18-1.35(\mathrm{~m}, 5 \mathrm{H}), 1.50-1.82(\mathrm{~m}$, 4H), 2.0-2.35 (m, 9H), $2.71-2.87(\mathrm{~m}, 3 \mathrm{H}), 3.06(\mathrm{~s}, 2 \mathrm{H}), 3.71(\mathrm{~s}, 2 \mathrm{H}), 5.05(\mathrm{~s}, 1 \mathrm{H}), 6.83(\mathrm{~s}$, 1H), $7.01(\mathrm{~s}, 1 \mathrm{H}), 7.26(\mathrm{~s}, 1 \mathrm{H}), 7.35(\mathrm{~d}, J=7.7 \mathrm{~Hz}, 1 \mathrm{H}), 7.44(\mathrm{t}, J=7.6,7.6 \mathrm{~Hz}, 1 \mathrm{H}), 7.52-$ $7.61(\mathrm{~m}, 1 \mathrm{H}), 7.92-8.02(\mathrm{~m}, 1 \mathrm{H}) 3 \mathrm{H}$ obscured; m/z (ESI) $599[\mathrm{M}+\mathrm{H}]^{+}$. 
(S)-4-Amino-6-((1-(3-methyl-6-(3-((4-(methyl(3,3,3-trifluoropropyl)amino)piperidin-1yl)methyl)phenyl)-5-oxo-5H-thiazolo[3,2-a]pyridin-7-yl)ethyl)amino)pyrimidine-5carbonitrile (20d)

${ }^{1} \mathrm{H}$ NMR (400 MHz, CD $\left.3 \mathrm{OD}\right) \delta$ 1.34-1.46 (m, 3H), 2.14 (s, 2H), 2.28-2.41 (m, 2H), 2.79$2.94(\mathrm{~m}, 8 \mathrm{H}), 3.18(\mathrm{t}, J=12.2 \mathrm{~Hz}, 2 \mathrm{H}), 3.47-3.53(\mathrm{~m}, 2 \mathrm{H}), 3.63-3.86(\mathrm{~m}, 3 \mathrm{H}), 4.41(\mathrm{~d}, J=$ 15.0 Hz, 2H), 5.00-5.21 (1H, m), $6.90(\mathrm{~s}, 1 \mathrm{H}), 7.05(\mathrm{~s}, 1 \mathrm{H}), 7.39-7.76(\mathrm{~m}, 4 \mathrm{H}), 8.10(\mathrm{~s}, 1 \mathrm{H})$; 3H obscured; ${ }^{19} \mathrm{~F}$ NMR (376 MHz; $\left.\mathrm{CD}_{3} \mathrm{OD}\right) \delta-66.6 ; \mathrm{m} / \mathrm{z}$ (ESI) $625[\mathrm{M}+\mathrm{H}]^{+}$.

(S)-4-Amino-6-((1-(3-methyl-6-(3-((4-(2-morpholinoethyl)piperazin-1yl)methyl)phenyl)-5-oxo-5H-thiazolo[3,2-a]pyridin-7-yl)ethyl)amino)pyrimidine-5carbonitrile (20e)

${ }^{1} \mathrm{H}$ NMR $\left(300 \mathrm{MHz}, \mathrm{CD}_{3} \mathrm{OD}\right) \delta 1.24-1.57(\mathrm{~m}, 3 \mathrm{H}), 2.35-2.63(\mathrm{~m}, 2 \mathrm{H}), 2.71-2.95(\mathrm{~m}$, $5 \mathrm{H}), 3.03-3.31(\mathrm{~m}, 7 \mathrm{H}), 3.44-3.72(\mathrm{~m}, 5 \mathrm{H}), 3.83-4.08(\mathrm{~m}, 4 \mathrm{H}), 4.3-4.52(\mathrm{~m}, 2 \mathrm{H}), 5.16$ (s, 1H), $6.91(\mathrm{~s}, 1 \mathrm{H}), 7.07(\mathrm{~s}, 1 \mathrm{H}), 7.36-7.55(\mathrm{~m}, 2 \mathrm{H}), 7.54-7.67(\mathrm{~m}, 1 \mathrm{H}), 7.78(\mathrm{~s}, 1 \mathrm{H}), 8.06$ $(\mathrm{s}, 1 \mathrm{H}) ; \mathrm{m} / \mathrm{z}(\mathrm{ESI}) 614[\mathrm{M}+\mathrm{H}]^{+}$.

(S)-4-amino-6-((1-(6-(3-((4-(isobutyl(methyl)amino)piperidin-1-yl)methyl)phenyl)-3methyl-5-oxo-5H-thiazolo[3,2-a]pyridin-7-yl)ethyl)amino)pyrimidine-5-carbonitrile (20f) ${ }^{1} \mathrm{H}$ NMR (500 MHz, DMSO-d6) $\delta 0.80(\mathrm{~d}, J=6.6 \mathrm{~Hz}, 6 \mathrm{H}), 1.22(\mathrm{~d}, J=7.0 \mathrm{~Hz}, 3 \mathrm{H}), 1.29$ $1.44(\mathrm{~m}, 2 \mathrm{H}), 1.46-1.66(\mathrm{~m}, 3 \mathrm{H}), 1.81-1.95(\mathrm{~m}, 2 \mathrm{H}), 2.05(\mathrm{~d}, J=6.9 \mathrm{~Hz}, 2 \mathrm{H}), 2.10(\mathrm{~s}, 3 \mathrm{H})$, $2.16-2.28(\mathrm{~m}, 1 \mathrm{H}), 2.68(\mathrm{~s}, 3 \mathrm{H}), 2.76-2.91(\mathrm{~m}, 2 \mathrm{H}), 3.44(\mathrm{brs}, 2 \mathrm{H}), 4.84-5.01($ brm, $1 \mathrm{H})$, $6.91-6.94(\mathrm{~m}, 1 \mathrm{H}), 6.98(\mathrm{~s}, 1 \mathrm{H}), 7.01-7.45(\mathrm{~m}, 6 \mathrm{H}), 7.47(\mathrm{~d}, J=7.0 \mathrm{~Hz}, 1 \mathrm{H}), 7.94(\mathrm{~s}, 1 \mathrm{H})$; ${ }^{13} \mathrm{C}$ NMR (126 MHz, DMSO-d6) $\delta$ 18.14, 20.49, 20.66 (2C), 26.03, 27.41 (2C), 38.04, 47.71, 52.93 (2C), 61.08, 61.40, 62.23, 67.90, 96.22, 107.55, 115.44, 120.38, 127.14, 127.54, $129.20,130.92,135.72,137.53,138.24,148.11,152.43,159.39,160.88,161.56,164.35 ; \mathrm{m} / \mathrm{z}$ (ESI) $585[\mathrm{M}+\mathrm{H}]^{+}$; HRMS calculated for $\mathrm{C}_{32} \mathrm{H}_{41} \mathrm{~N}_{8} \mathrm{OS}[(\mathrm{M}+\mathrm{H})+]$, 585.3124; found, 585.3109 
(S)-4-Amino-6-((1-(3-methyl-6-(3-((4-((methyl(pyridin-2-

ylmethyl)amino)methyl)piperidin-1-yl)methyl)phenyl)-5-oxo-5H-thiazolo[3,2-a]pyridin7-yl)ethyl)amino)pyrimidine-5-carbonitrile formic acid salt (20g)

${ }^{1} \mathrm{H}$ NMR (400 MHz, CD $\left.3 \mathrm{OD}\right) \delta 1.18-1.48(\mathrm{~m}, 5 \mathrm{H}), 1.82-2.17(\mathrm{~m}, 3 \mathrm{H}), 2.33(\mathrm{~s}, 3 \mathrm{H}), 2.41$ $(\mathrm{d}, J=5.5 \mathrm{~Hz}, 2 \mathrm{H}), 2.81(\mathrm{~s}, 3 \mathrm{H}), 2.9-3.05(\mathrm{~m}, 2 \mathrm{H}), 3.39-3.61(\mathrm{~m}, 2 \mathrm{H}), 3.74(\mathrm{~s}, 2 \mathrm{H}), 4.17-$ $4.37(\mathrm{~m}, 2 \mathrm{H}), 4.93-5.16(\mathrm{~m}, 1 \mathrm{H}), 6.87(\mathrm{~s}, 1 \mathrm{H}), 7.05(\mathrm{~s}, 1 \mathrm{H}), 7.3-7.35(\mathrm{~m}, 1 \mathrm{H}), 7.35-7.79$ (m, 5H), $7.79-7.86(\mathrm{~m}, 1 \mathrm{H}), 7.96(\mathrm{~s}, 1 \mathrm{H}), 8.42(\mathrm{brs}, 1 \mathrm{H}), 8.48(\mathrm{~d}, J=4.4 \mathrm{~Hz}, 1 \mathrm{H}) ; \mathrm{m} / \mathrm{z}(\mathrm{ESI})$ $634[\mathrm{M}+\mathrm{H}]^{+}$.

(S)-4-Amino-6-((1-(6-(3-((ethyl(2-morpholinoethyl)amino)methyl)phenyl)-3-methyl-5oxo-5H-thiazolo[3,2-a]pyridin-7-yl)ethyl)amino)pyrimidine-5-carbonitrile (20h)

Sodium cyanoborohydride (23 mg, $0.37 \mathrm{mmol})$ was added to (S)-4-amino-6-((1-(3-methyl6-(3-(((2-morpholinoethyl)amino)methyl)phenyl)-5-oxo-5H-thiazolo[3,2-a]pyridin-7-

yl)ethyl)amino)pyrimidine-5-carbonitrile (20a, $100 \mathrm{mg}, 0.18 \mathrm{mmol})$, acetaldehyde (12 mg, $0.28 \mathrm{mmol})$ and acetic acid $(0.053 \mathrm{~mL}, 0.92 \mathrm{mmol})$ in $\mathrm{CH}_{2} \mathrm{Cl}_{2}(5 \mathrm{~mL})$ and $\mathrm{MeOH}(10 \mathrm{~mL})$ at $25{ }^{\circ} \mathrm{C}$. The resulting mixture was stirred at $25^{\circ} \mathrm{C}$ for 12 hours. The solvent was removed under reduced pressure. The crude product was purified by preparative HPLC (Phenomenex Gemini-NX axia Prep C18 OBD column, $5 \mu$ silica, $19 \mathrm{~mm}$ diameter, $100 \mathrm{~mm}$ length), using decreasingly polar mixtures of water (containing $1 \% \mathrm{NH}_{4} \mathrm{HCO}_{3}$ ) and $\mathrm{MeCN}$ as eluents to give the title compound (55 mg, $52 \%$ ) as a white solid.

${ }^{1} \mathrm{H}$ NMR (300 MHz, CD $\left.\mathrm{OD}\right): \delta 1.05-1.13(\mathrm{~m}, 3 \mathrm{H}), 1.23-1.33(\mathrm{~m}, 3 \mathrm{H}), 2.38-2.80(\mathrm{~m}$, $10 \mathrm{H}), 2.85(\mathrm{~s}, 3 \mathrm{H}), 3.54-3.84(\mathrm{~m}, 6 \mathrm{H}), 5.03-5.12(\mathrm{~m}, 1 \mathrm{H}), 6.81(\mathrm{~d}, J=1.2 \mathrm{~Hz}, 1 \mathrm{H}), 6.99(\mathrm{~s}$, 1H), 7.14 - $7.67(\mathrm{~m}, 4 \mathrm{H}), 7.94-8.02(\mathrm{~m}, 1 \mathrm{H}) ; \mathrm{m} / \mathrm{z}(\mathrm{ESI}) 573[\mathrm{M}+\mathrm{H}]^{+}$.

(S)-4-Amino-6-((1-)(6-(3-)((3-)((4-

chlorobenzyl)(methyl)amino)propyl)(methyl)amino)methyl)phenyl)-3-methyl-5-oxo-5Hthiazolo[3,2-a]pyridin-7-yl)ethyl)amino)pyrimidine-5-carbonitrile (20i) 
Prepared from aldehyde 16 and $\mathrm{N}^{1}$-(4-chlorobenzyl)- $\mathrm{N}^{1}$-methylpropane-1,3-diamine according to the standard procedure followed by a reductive amination with formaldehyde following the procedure of Example 20d step 2.

${ }^{1} \mathrm{H}$ NMR (400MHz; $\left.\mathrm{CD}_{3} \mathrm{OD}\right): \delta 1.28$ (s, 3H), $1.72(\mathrm{~s}, 2 \mathrm{H}), 2.12(\mathrm{~d}, J=18.0 \mathrm{~Hz}, 3 \mathrm{H}), 2.30-$ $2.40(\mathrm{~m}, 2 \mathrm{H}), 2.63-2.74(\mathrm{~m}, 2 \mathrm{H}), 2.78(\mathrm{~s}, 3 \mathrm{H}), 3.43(\mathrm{~d}, J=20.4 \mathrm{~Hz}, 2 \mathrm{H}), 3.84(\mathrm{~s}, 2 \mathrm{H}), 5.08(\mathrm{~s}$, 1H), $6.81(\mathrm{~s}, 1 \mathrm{H}), 6.99(\mathrm{~s}, 1 \mathrm{H}), 7.23(\mathrm{~s}, 5 \mathrm{H}), 7.34(\mathrm{~d}, J=7.6 \mathrm{~Hz}, 1 \mathrm{H}), 7.44(\mathrm{t}, J=7.6 \mathrm{~Hz}, 1 \mathrm{H})$, $7.59(\mathrm{~s}, 1 \mathrm{H}), 7.99(\mathrm{~s}, 1 \mathrm{H}) ; \mathrm{m} / \mathrm{z}(\mathrm{ESI}) 627 / 629\left(\mathrm{Cl}\right.$ pattern) $[\mathrm{M}+\mathrm{H}]^{+}$.

\section{4-Amino-6-(((S)-1-(6-(3-)((3-)((2R,6S)-2,6-}

dimethylmorpholino)propyl)(methyl)amino)methyl)phenyl)-3-methyl-5-oxo-5Hthiazolo[3,2-a]pyridin-7-yl)ethyl)amino)pyrimidine-5-carbonitrile (20j)

Prepared from aldehyde 16 and 3-((2R,6S)-2,6-dimethylmorpholino)propan-1-amine according to the standard procedure followed by a reductive amination with formaldehyde following the procedure of Example 20d step 2.

${ }^{1} \mathrm{H}$ NMR (300MHz; CD $\left.{ }_{3} \mathrm{OD}\right) \delta 1.24(\mathrm{~d}, J=6.3 \mathrm{~Hz}, 6 \mathrm{H}), 1.31-1.53(\mathrm{~m}, 3 \mathrm{H}), 2.15-2.37$ (m, 2H), $2.69(\mathrm{t}, J=11.5,11.5 \mathrm{~Hz}, 2 \mathrm{H}), 2.78-2.86(\mathrm{~m}, 3 \mathrm{H}), 2.93(\mathrm{~s}, 3 \mathrm{H}), 3.1-3.24(\mathrm{~m}, 2 \mathrm{H})$, $3.24-3.31(\mathrm{~m}, 2 \mathrm{H}), 3.41-3.56(\mathrm{~m}, 2 \mathrm{H}), 3.8-3.98(\mathrm{~m}, 2 \mathrm{H}), 4.34-4.54(\mathrm{~m}, 2 \mathrm{H}), 4.99-5.25$ (m, 1H), $6.90(\mathrm{~s}, 1 \mathrm{H}), 7.06(\mathrm{~s}, 1 \mathrm{H}), 7.34-7.82(\mathrm{~m}, 4 \mathrm{H}), 8.12(\mathrm{~s}, 1 \mathrm{H}) ; \mathrm{m} / \mathrm{z}(\mathrm{ESI}) 601[\mathrm{M}+\mathrm{H}]^{+}$.

\section{(S)-4-amino-6-((1-)(6-)(3-)((4-}

(benzyl(methyl)amino)butyl)(methyl)amino)methyl)phenyl)-3-methyl-5-oxo-5Hthiazolo[3,2-a]pyridin-7-yl)ethyl)amino)pyrimidine-5-carbonitrile (20k)

\section{Step 1}

Sodium cyanoborohydride ( $88 \mathrm{mg}, 1.39 \mathrm{mmol}$ ) was added in one portion to (S)-4-amino-6((1-(6-(3-formylphenyl)-3-methyl-5-oxo-5H-thiazolo[3,2-a]pyridin-7-

yl)ethyl)amino)pyrimidine-5-carbonitrile (300 mg, $0.70 \mathrm{mmol})$, 4,4-diethoxybutan-1-amine (337 mg, $2.09 \mathrm{mmol})$ and $\mathrm{AcOH}(0.2 \mathrm{~mL}, 3.48 \mathrm{mmol})$ in $\mathrm{CH}_{2} \mathrm{Cl}_{2}(10 \mathrm{~mL})$ and $\mathrm{MeOH}(10 \mathrm{ml})$ 
at $25{ }^{\circ} \mathrm{C}$ over a period of 15 minutes under nitrogen. The resulting mixture was stirred at $25{ }^{\circ} \mathrm{C}$ for 2 hours. The solvent was removed under reduced pressure and the residue was quenched with saturated $\mathrm{NaHCO}_{3}(10 \mathrm{~mL})$, extracted with $\mathrm{CH}_{2} \mathrm{Cl}_{2}(3 \times 10 \mathrm{~mL})$, the organic layer was dried over $\mathrm{Na}_{2} \mathrm{SO}_{4}$, filtered and evaporated to give (S)-4-amino-6-((1-(6-(3-)((4,4diethoxybutyl)amino)methyl)phenyl)-3-methyl-5-oxo-5H-thiazolo[3,2-a]pyridin-7yl)ethyl)amino)pyrimidine-5-carbonitrile (380 mg, $95 \%$ ) as a yellow liquid.

The product was used in the next step directly without further purification.

\section{Step 2}

Sodium cyanoborohydride (87 mg, $1.39 \mathrm{mmol}$ ) was added in one portion to (S)-4-amino-6((1-(6-(3-(((4,4-diethoxybutyl)amino)methyl)phenyl)-3-methyl-5-oxo-5H-thiazolo[3,2a]pyridin-7-yl)ethyl)amino)pyrimidine-5-carbonitrile (400 mg, $0.69 \mathrm{mmol})$, formaldehyde (31 $\mathrm{mg}, 1.0 \mathrm{mmol})$ and acetic acid $(209 \mathrm{mg}, 3.47 \mathrm{mmol})$ in $\mathrm{MeOH}(20 \mathrm{~mL})$ at $25^{\circ} \mathrm{C}$ over a period of 25 minutes under nitrogen. The resulting mixture was stirred at $25{ }^{\circ} \mathrm{C}$ for 2 hours. The reaction mixture was quenched with saturated $\mathrm{NaHCO}_{3}(25 \mathrm{~mL})$ and extracted with EtOAc (3 x $25 \mathrm{~mL}$ ). The organic layer was dried over $\mathrm{Na}_{2} \mathrm{SO}_{4}$, filtered and evaporated to give (S)-4amino-6-((1-(6-(3-(((4,4-diethoxybutyl)(methyl)amino)methyl)phenyl)-3-methyl-5-oxo-5Hthiazolo[3,2-a]pyridin-7-yl)ethyl)amino)pyrimidine-5-carbonitrile (320 $\mathrm{mg}, 78 \%$ ) as a yellow oil.

The product was used in the next step directly without further purification.

\section{Step 3}

TFA (3.38 mL, $44 \mathrm{mmol})$ was added portionwise to a cold $\left(0{ }^{\circ} \mathrm{C}\right)$ solution of $(\mathrm{S})$-4-amino-6((1-(6-(3-(((4,4-diethoxybutyl)(methyl)amino)methyl)phenyl)-3-methyl-5-oxo-5Hthiazolo[3,2-a]pyridin-7-yl)ethyl)amino)pyrimidine-5-carbonitrile (400 $\mathrm{mg}, 0.68 \mathrm{mmol})$ in $\mathrm{CHCl}_{3}(40 \mathrm{~mL})$ and $\mathrm{H}_{2} \mathrm{O}(5 \mathrm{ml})$ over a period of 15 minutes. The resulting solution was stirred at $25^{\circ} \mathrm{C}$ for 2 hours. The reaction mixture was quenched with saturated $\mathrm{NaHCO}_{3}(25 \mathrm{~mL})$, 
extracted with $\mathrm{CH}_{2} \mathrm{Cl}_{2}(3 \times 25 \mathrm{~mL})$, the organic layer was dried over $\mathrm{Na}_{2} \mathrm{SO}_{4}$, filtered and evaporated to give (S)-4-amino-6-((1-(3-methyl-6-(3-((methyl(4oxobutyl)amino)methyl)phenyl)-5-oxo-5H-thiazolo[3,2-a]pyridin-7-

yl)ethyl)amino)pyrimidine-5-carbonitrile (350 mg, $100 \%$ ) as a yellow solid.

\section{Step 4-(S)-4-amino-6-((1-(6-)(3-(((4-}

\section{(benzyl(methyl)amino)butyl)(methyl)amino)methyl)phenyl)-3-methyl-5-oxo-5H-}

\section{thiazolo[3,2-a]pyridin-7-yl)ethyl)amino)pyrimidine-5-carbonitrile}

Sodium cyanoborohydride $(24 \mathrm{mg}, 0.39 \mathrm{mmol}$ ) was added in one portion to (S)-4-amino-6((1-(3-methyl-6-(3-((methyl(4-oxobutyl)amino)methyl)phenyl)-5-oxo-5H-thiazolo[3,2a]pyridin-7-yl)ethyl)amino)pyrimidine-5-carbonitrile (100 mg, $0.19 \mathrm{mmol}$ ), N-methyl-1phenylmethanamine $(47 \mathrm{mg}, 0.39 \mathrm{mmol})$ and acetic acid $(58 \mathrm{mg}, 0.97 \mathrm{mmol})$ in $\mathrm{CH}_{2} \mathrm{Cl}_{2}(10$ $\mathrm{mL})$ and $\mathrm{MeOH}(10 \mathrm{ml})$ at $25^{\circ} \mathrm{C}$ over a period of 15 minutes under nitrogen. The resulting solution was stirred at $25^{\circ} \mathrm{C}$ for 12 hours. The solvent was removed under reduced pressure. The crude product was purified by preparative HPLC (XBridge Prep C18 OBD column, $5 \mu$ silica, $19 \mathrm{~mm}$ diameter, $150 \mathrm{~mm}$ length; water $(0.5 \% \mathrm{TFA})$ and $\mathrm{MeCN})$ to give the title compound ( $89 \mathrm{mg}, 62 \%)$ as a yellow solid.

${ }^{1} \mathrm{H}$ NMR (300MHz; CD $\left.3 \mathrm{OD}\right) \delta$ 1.36-1.42 (3H, m), $1.76-1.90(4 \mathrm{H}, \mathrm{m}), 2.73-2.80(6 \mathrm{H}, \mathrm{m})$, $2.90(3 \mathrm{H}, \mathrm{brs}), 3.08-3.31(4 \mathrm{H}, \mathrm{m}), 4.30-4.49(4 \mathrm{H}, \mathrm{m}), 4.98-5.18(1 \mathrm{H}, \mathrm{m}), 6.89(1 \mathrm{H}, \mathrm{s}), 7.07$ $(1 \mathrm{H}, \mathrm{s}), 7.45-7.77(9 \mathrm{H}, \mathrm{m}), 8.05(1 \mathrm{H}, \mathrm{s}) 4 \mathrm{H}$ obscured; m/z (ESI) $621[\mathrm{M}+\mathrm{H}]^{+}$.

$$
\text { 4-Amino-6-(((S)-1-(6-(3-(((4-((2S,6R)-2,6- }
$$

dimethylmorpholino)butyl)(methyl)amino)methyl)phenyl)-3-methyl-5-oxo-5Hthiazolo[3,2-a]pyridin-7-yl)ethyl)amino)pyrimidine-5-carbonitrile (201)

$$
\text { Prepared from } \quad \text { (S)-4-amino-6-((1-(3-methyl-6-(3-)(methyl(4- }
$$
oxobutyl)amino)methyl)phenyl)-5-oxo-5H-thiazolo[3,2-a]pyridin-7- 
yl)ethyl)amino)pyrimidine-5-carbonitrile (step 3 20k) and (2S,6R)-2,6-dimethylmorpholine under the conditions of step $4 \mathbf{2 0 k}$.

${ }^{1} \mathrm{H}$ NMR (300MHz; CD $\left.3 \mathrm{OD}\right) \delta 1.24(\mathrm{~d}, J=6.3 \mathrm{~Hz}, 5 \mathrm{H}), 1.29-1.49(\mathrm{~m}, 3 \mathrm{H}), 1.7-1.96(\mathrm{~m}$, 4H), $2.67(\mathrm{t}, J=11.5 \mathrm{~Hz}, 2 \mathrm{H}), 2.82(\mathrm{~s}, 3 \mathrm{H}), 2.89(\mathrm{~s}, 3 \mathrm{H}), 3.1-3.31(\mathrm{~m}, 5 \mathrm{H}), 3.4-3.52(\mathrm{~m}$, 2H), $3.79-3.96(\mathrm{~m}, 2 \mathrm{H}), 4.25-4.56(\mathrm{~m}, 2 \mathrm{H}), 4.98-5.25(\mathrm{~m}, 1 \mathrm{H}), 6.91(\mathrm{~s}, 1 \mathrm{H}), 7.07(\mathrm{~s}, 1 \mathrm{H})$, $7.38-7.82(\mathrm{~m}, 4 \mathrm{H}), 8.09(\mathrm{~s}, 1 \mathrm{H}) ; \mathrm{m} / \mathrm{z}(\mathrm{ESI}) 615[\mathrm{M}+\mathrm{H}]^{+}$.

\section{Enzymatic activity assay for recombinant human PI3Ka, $\beta, \delta$ and $\gamma$.}

The activity of recombinant human PI3K $\gamma$ ((aa144-1102)-6His) and PI3K $\alpha, \beta, \delta$ (6His $(\mathrm{p} 110-\mathrm{p} 85 \alpha)$ was determined by measuring the ADP level after phosphorylation of $\mathrm{DiC}_{8^{-}}$ $\mathrm{PIP}_{2}$ using a commercially available ADP-Glo ${ }^{\mathrm{TM}}$ kit from Promega. The assay was carried out in white low volume 384 well plates in a final volume of $14 \mu 1$ at R.T. The assay conditions contained the following: $50 \mathrm{mM}$ Tris buffer $\mathrm{pH}$ 7.4, $2.1 \mathrm{mM}$ DTT, $3 \mathrm{mM} \mathrm{MgCl}$, $0.05 \%$ CHAPS, $20 \mu \mathrm{M}$ ATP, $80 \mu \mathrm{M} \mathrm{DiC}_{8}-\mathrm{PIP}_{2}$ and $1.2 \mathrm{nM}$ PI3K $\alpha, \beta, \gamma$ or $0.6 \mathrm{nM}$ PI3K $\delta$. Potential inhibitors were made up in DMSO and then diluted in the assay to give a final concentration of not exceeding 1\% (v/v) DMSO. A 10-point half-log dilution series of the inhibitors (highest concentration typically $0.1 \mu \mathrm{M}$ for $\delta, \gamma$ and $33 \mu \mathrm{M}$ for $\alpha, \beta$ ) was tested and the $\mathrm{pIC}_{50}$ determined using a 4-paramater logistic equation in a non-linear curve fitting routine. Routinely, inhibitors were pre-incubated with $3 \mu 1$ of enzyme for 15 min prior to the addition of $2 \mu 1$ substrate mixture for a further 60 min enzyme reaction. The phosphorylation was stopped with the addition of $3 \mu \mathrm{ADP}-\mathrm{Glo}^{\mathrm{TM}}$ reagent (stop solution) followed by a 40 min incubation. Prior to detection $6 \mu \mathrm{l}$ of ADP-Glo ${ }^{\mathrm{TM}}$ Kinase Detection Reagent was added and the plates were read in a micro plate reader using a Luminescence filter. All additions were followed by a short centrifugation step.

Inhibition of cellular activity in JeKo-1 cells. 
PI3K $\delta$ inhibitors were identified by measuring the phosphorylation of AKT (at Ser473) using TR-FRET technology (Phospho-AKT (Ser473) kit, Cisbio) in JeKo-1 cells Lymphoblast B cell line (ATCC). Cryogenically preserved cells were thawed rapidly in RPMI 1640 medium (10\% FBS, $2 \mathrm{mM}$ Glutamine) at $37^{\circ} \mathrm{C}$. Cells were plated in white low volume 384 well plates at a density of $1.25 \mathrm{E} 6$ cells/ml in assay buffer (RPMI 1640 medium, 2 mM Glutamine). Potential inhibitors were made up in DMSO and then diluted in the assay to give a final concentration of not exceeding 1\% (v/v) DMSO. A 10-point half-log dilution series of the inhibitors (highest concentration typically $1 \mu \mathrm{M}$ ) was tested and the $\mathrm{pIC}_{50}$ determined using a 4-paramater logistic equation in a non-linear curve fitting routine. Inhibitors were incubated with $8 \mu \mathrm{l}$ of cells for $60 \mathrm{~min}$ at $30{ }^{\circ} \mathrm{C}$ previously stimulated with 2 $\mu 1$ Anti-IgM $(250 \mathrm{ng} / \mathrm{ml})$ in assay buffer. After an incubation of $10 \mathrm{~min}$ at $37^{\circ} \mathrm{C}$ the cells were lysed for $30 \mathrm{~min}$ at RT on a plate shaker at $500 \mathrm{rpm}$. A $5 \mu 1 \mathrm{mix}$ of d2/cryptate was added to the plates and the FRET signals were read in a micro plate reader after 3-4 $\mathrm{h}$ at 620 $\mathrm{nm} \& 665 \mathrm{~nm}$.

\section{Rat intratracheal instillation to determine the lung retention of inhaled compounds}

All rat experiments were approved by the Gothenburg Ethics Committee for Experimental Animals in Sweden and conform to Directive 2010/63/EU, ethical license No. 135-2014

The lung half-lives and percentage remaining in the lung at $4 \mathrm{~h}$ of the compounds were determined after intratracheal instillation as previously described. ${ }^{34}$ The terminal phase of the time-concentration curve was used for determination of the half-lives. Briefly, a special cannula, connected to a syringe, was inserted in the trachea at the first bifurcation and 0.5 $\mathrm{mL} / \mathrm{kg}$ was instilled into the trachea. Sampling of lungs were made at predefined time-points, and the lungs were placed on ice and stored at $-20^{\circ} \mathrm{C}$ until homogenization (Bertin technologies) prior to analysis with LC-MS/MS.

\section{Target engagement in vivo model}


All mouse experiments were approved by the Gothenburg Ethics Committee for Experimental Animals in Sweden and conform to Directive 2010/63/EU, ethical license No.

\section{7-2013}

The T-cell receptor transgenic mouse (OT-II; C57BL/6-Tg(TcraTcrb) $425 \mathrm{Cbn} / \mathrm{Crl}^{28}$ was ordered (Charles River, Sulzfeld, Germany) as 8-10 weeks of age, randomized upon arrival, and allowed to acclimatise at least 1 week in the animal facility before the experimental start.

The mice were OVA (Albumin chicken egg, grade V (Sigma-Aldrich), Sweden, \#A5503) challenged on day 0 by intranasal administration $(50 \mu \mathrm{g} /$ mouse in $50 \mu \mathrm{L}$ saline) to stimulate and recruit inflammatory cells locally to the lung. Five days later, the lung T-cells were activated by the intranasal administration of $0.5 \mu \mathrm{g}$ anti-CD3 (clone 145-2C11, Cat\# 553057 from BD Bioscience) per mouse in $50 \mu \mathrm{L}$ saline. Isotype Hamster IgG1 (clone A19-3 Cat\# 553968 from BD Bioscience) was used as control. The animals were $(2.5 \mathrm{~mL} / \mathrm{kg} \mathrm{Bw})$ treated intratracheally with $\mathrm{PI} 3 \mathrm{~K} \delta$ inhibitor (or vehicle for control animals) 18 hours prior to antiCD3 challenge. The bronchoalveolar lung lavage (BAL) cells were isolated 6 hours after anti-CD3 challenge, fixed by Phosflow Fix buffer I and permeabilised by permeabilisation buffer III (both from BD Bioscience). Cells were then stained with phospho-S6 Ribosomal Protein (Ser235/236) (D57.2.2E) XP®Rabbit mAb (AlexaFluor488 Conjugate, Cell Signaling Technology) and data were collected using a LSRFortessa cell analyser (BD Biosciences). Data analysis was performed using FlowJo (Tree Star) software.

\section{Supporting Information}

Ligand diagrams for the crystal structures; Kinase selectivity profile for $\mathbf{2 0 b} \& \mathbf{2 0 f}$; Analytical HPLC conditions; HPLCMS results; Synthesis procedures for compounds 1 \& 2; NMR spectra for compounds 3-201; HPLCMS traces for compounds 20b \& 20f

This material is available free of charge via the Internet at http://pubs.acs.org 


\section{AUTHOR INFORMATION}

\section{Corresponding Author}

*(MWDP) e-mail matthew.perry@astrazeneca.com

\section{Present Addresses}

Neil Holden : University of Lincoln, Brayford Pool, Lincoln, Lincolnshire, LN6 7TS, United Kingdom

\section{Author Contributions}

The manuscript was written through contributions of all authors. All authors have given approval to the final version of the manuscript.

\section{ACKNOWLEDGMENT}

We would like to thank our colleagues in the analytical and purification departments at both AstraZeneca R\&D Mölndal and Pharmaron Beijing for their support with purification and characterisation of the compounds described in this work. We would also like to thank the colleagues at AstraZeneca and Pharmaron whose testing of the compounds provided the results which are described.

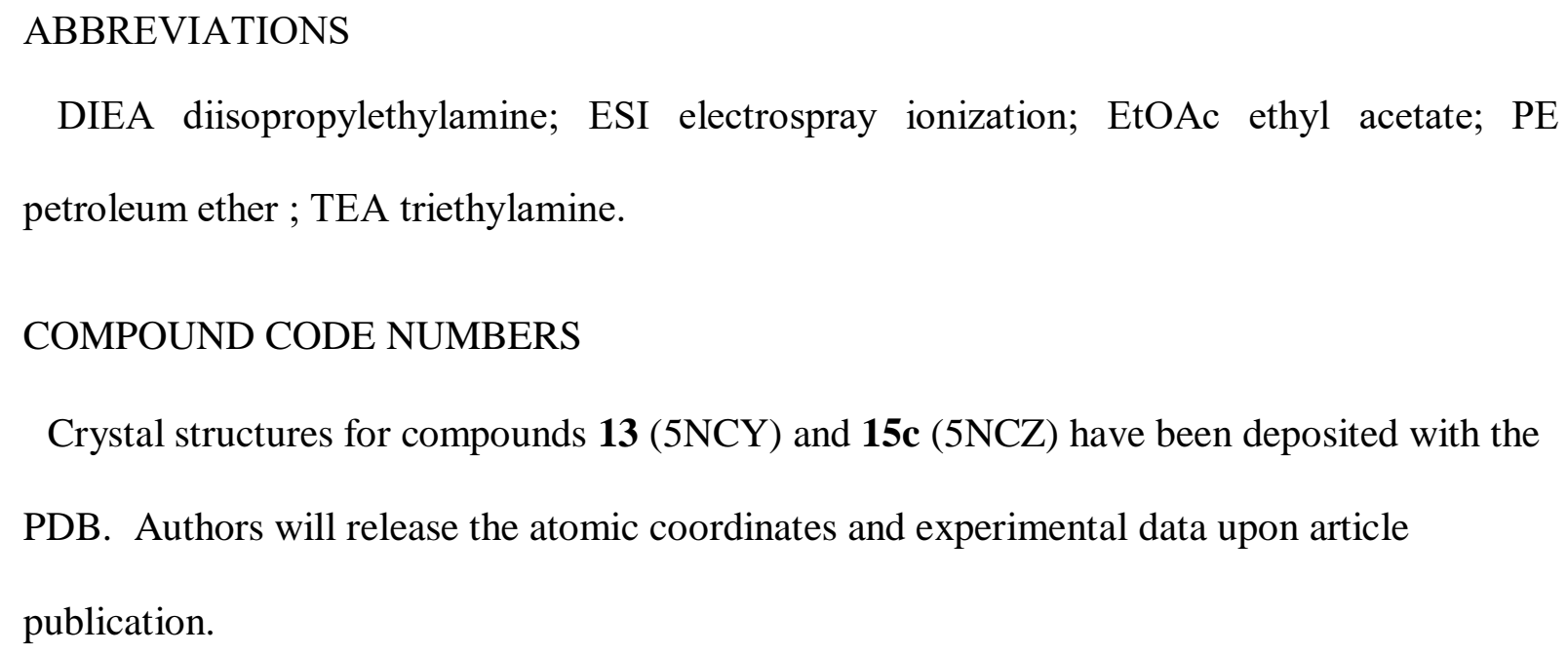

DIEA diisopropylethylamine; ESI electrospray ionization; EtOAc ethyl acetate; PE petroleum ether; TEA triethylamine.

COMPOUND CODE NUMBERS

Crystal structures for compounds 13 (5NCY) and 15c (5NCZ) have been deposited with the PDB. Authors will release the atomic coordinates and experimental data upon article publication. 


\section{REFERENCES}

(1) Fruman, D.; Rommel, C. PI3K and Cancer: Lessons, Challenges and Opportunities. Nat. Rev. Drug Discovery 2014, 13, 140-156.

(2) Yap, T.; Bjerke, L.; Clarke, P.; Workman, P. Drugging PI3K in Cancer: Refining Targets and Therapeutic Strategies. Curr. Opin. Pharmacol. 2015, 23, 98-107.

(3) Cushing, T. D.; Metz, D. P.; Whittington, D.; McGee, L. R. PI3K $\delta$ and PI3K $\gamma$ as Targets for Autoimmune and Inflammatory Diseases. J. Med. Chem. 2012, 55, 85598581.

(4) Rowan, W. C.; Smith, J. L.; Affleck, K.; Amour, A. Targeting Phosphoinositide 3Kinase $\delta$ for Allergic Asthma. Biochem. Soc. Trans. 2012, 40, 240-245.

(5) Puri, K. D.; Gold, M. R. Selective Inhibitors of Phosphoinositide 3-Kinase Delta: Modulators of B-Cell Function with Potential for Treating Autoimmune Inflammatory Diseases and B-Cell Malignancies. Front. Immunol. 2012, 3, 256.

(6) Sriskantharajah, S.; Hamblin, N.; Worsley, S.; Calver, A. R.; Hessel, E. M.; Amour, A. Targeting Phosphoinositide 3-Kinase $\delta$ for the Treatment of Respiratory Diseases. Ann. N. Y. Acad. Sci. 2013, 1280, 35-39.

(7) Hawkins, P. T.; Stephens, L. R. PI3K Signalling in Inflammation. Biochim. Biophys. Acta - Mol. Cell Biol. Lipids 2015, 1851, 882-897.

(8) So, L.; Fruman, D. PI3K Signalling in B- and T-Lymphocytes: New Developments and Therapeutic Advances. Biochem. J. 2012, 442, 465-481.

(9) Fung-Leung, W.-P. Phosphoinositide 3-Kinase Gamma in T Cell Biology and Disease Therapy. Ann. N. Y. Acad. Sci. 2013, 1280, 40-43.

(10) Vanhaesebroeck, B.; Whitehead, M. A.; Piñeiro, R. Molecules in Medicine MiniReview: Isoforms of PI3K in Biology and Disease. J. Mol. Med. 2016, 94, 5-11.

(11) Markham, A. Idelalisib: First Global Approval. Drugs 2014, 74, 1701-1707. 
(12) Coutre, S. E.; Barrientos, J. C.; Brown, J. R.; de Vos, S.; Furman, R. R.; Keating, M. J.; Li, D.; O’Brien, S. M.; Pagel, J. M.; Poleski, M. H.; Sharman, J. P.; Yao, N.-S.; Zelenetz, A. D. Management of Adverse Events Associated with Idelalisib Treatment Expert Panel Opinion. Leuk. Lymphoma 2015, 56, 2779-2786.

(13) Terstiege, I.; Perry, M.; Petersen, J.; Tyrchan, C.; Svensson, T.; Lindmark, H.; Öster, L. Discovery of Triazole Aminopyrazines as a Highly Potent and Selective Series of PI3K $\delta$ Inhibitors. Bioorg. Med. Chem. Lett. 2016, 27, 679-687.

(14) El-Sherbiny, I. M.; El-baz, N. M.; Yacoub, M. H. Inhaled Nano- and Microparticles for Drug Delivery. Global Cardiol. Sci. Pract. 2015, 2015, 2.

(15) Cushing, T. D.; Metz, D. P.; Whittington, D. A.; McGee, L. R. PI3K $\delta$ and PI3K $\gamma$ as Targets for Autoimmune and Inflammatory Diseases. J. Med. Chem. 2012, 55, 85598581.

(16) Knight, Z. A.; Gonzalez, B.; Feldman, M. E.; Zunder, E. R.; Goldenberg, D. D.; Williams, O.; Loewith, R.; Stokoe, D.; Balla, A.; Toth, B.; Balla, T.; Weiss, W. A.; Williams, R. L.; Shokat, K. M. A Pharmacological Map of the PI3-K Family Defines a Role for p110alpha in Insulin Signaling. Cell 2006, 125, 733-747.

(17) Sutherlin, D. P.; Baker, S.; Bisconte, A.; Blaney, P. M.; Brown, A.; Chan, B. K.; Chantry, D.; Castanedo, G.; Depledge, P.; Goldsmith, P.; Goldstein, D. M.; Hancox, T.; Kaur, J.; Knowles, D.; Kondru, R.; Lesnick, J.; Lucas, M. C.; Lewis, C.; Murray, J.; Nadin, A. J.; Nonomiya, J.; Pang, J.; Pegg, N.; Price, S.; Reif, K.; Safina, B. S.; Salphati, L.; Staben, S.; Seward, E. M.; Shuttleworth, S.; Sohal, S.; Sweeney, Z. K.; Ultsch, M.; Waszkowycz, B.; Wei, B. Potent and Selective Inhibitors of PI3K $\delta$ : Obtaining Isoform Selectivity from the Affinity Pocket and Tryptophan Shelf. Bioorg. Med. Chem. Lett. 2012, 22, 4296-4302. 
(18) Sadhu, C.; Masinovsky, B.; Dick, K.; Sowell, C. G.; Staunton, D. E. Essential Role of Phosphoinositide 3-Kinase $\delta$ in Neutrophil Directional Movement. J. Immunol. 2003, $170,2647-2654$.

(19) Zhao, X.; Li, T.; Zhou, Z.; Chen, L.; Liu, Q.; Wang, X.; Yang, L.; Rong, Y.; Tan, R.; Yu, C.; Jiang, L.; Liu, Y.; Linghu, L.; Sun, J.; Wang, W. Certain Protein Kinase Inhibitors. WO2016066142(A1). 2016.

(20) Emtenaes, H; Alderin, L; Almqvist, F. An Enantioselective Ketene-Imine Cycloaddition Method for Synthesis of Substituted Ring-Fused 2-Pyridinones. J. Org. Chem. 2001, 66, 6756-6761.

(21) Bengtsson, C.; Almqvist, F. Regioselective Halogenations and Subsequent SuzukiMiyaura Coupling onto Bicyclic 2-Pyridones. J. Org. Chem. 2010, 75, 972-975.

(22) Hochhaus, G.; Möllmann, H.; Derendorf, H.; Gonzalez-Rothi, R. J. Pharmacokinetic/pharmacodynamic Aspects of Aerosol Therapy Using Glucocorticoids as a Model. J. Clin. Pharmacol. 1997, 37, 881-892.

(23) Hochhaus, G.; Gonzalez-Rothi, R. J.; Lukyanov, A.; Derendorf, H.; Schreier, H.; Dalla Costa, T. Assessment of Glucocorticoid Lung Targeting by Ex-Vivo Receptor Binding Studies in Rats. Pharm. Res. 1995, 12, 134-137.

(24) Cooper, A.E. Ferguson, D. and G. K. Optimisation of DMPK by the Inhaled Route. Challenges Approaches Curr. Drug Metab. 2012, 13, 457-473.

(25) Austin, R. P.; Barton, P.; Bonnert, R. V; Brown, R. C.; Cage, P. A.; Cheshire, D. R.; Davis, A. M.; Dougall, I. G.; Ince, F.; Pairaudeau, G.; Young, A. QSAR and the Rational Design of Long-Acting Dual D 2 -Receptor / 2 -Adrenoceptor Agonists Approach to Compound Design J. Med. Chem. 2003, 46, 3210-3220.

(26) Connolly, S.; Alcaraz, L.; Bailey, A.; Cadogan, E.; Christie, J.; Cook, A. R.; Fisher, A. J.; Hill, S.; Humphries, A.; Ingall, A. H.; Kane, Z.; Paine, S.; Pairaudeau, G.; Stocks, 
M. J.; Young, A. Design-Driven LO: The Discovery of New Ultra Long Acting Dibasic B2-Adrenoceptor Agonists. Bioorg. Med. Chem. Lett. 2011, 21, 4612-4616.

(27) Mindell, J. A. Lysosomal Acidification Mechanisms. Annu. Rev. Physiol. 2012, 74, 6986.

(28) Barnden, M. J.; Allison, J.; Heath, W. R.; Carbone, F. R. Defective TCR Expression in Transgenic Mice Constructed Using cDNA-Based Alpha- and Bold Beta-Chain Genes under the Control of Heterologous Regulatory Elements. Immunol. Cell Biol. 1998, 76, $34-40$.

(29) Meyuhas, O.; Dreazen, A. Chapter 3 Ribosomal Protein S6 Kinase: From TOP mRNAs to Cell Size. Prog. Mol. Biol. Transl. Sci. 2009, 90, 109-153.

(30) Beger, J.; Schöde, D.; Vogel, J. Dreikomponentenreaktionen. II. Nucleophile Substitutionen an N-( $\beta$-Haloalkyl)-Imidhalogeniden die Darstellung von $\Delta 2$ Oxazolinen, $\Delta 2$-Thiazolinen und $\Delta 2$-Imidazolinen. J. Prakt. Chem. (Weinheim, Ger.) 1969, 311, 408-419.

(31) Clark, J.; Bahman Parvizi, R. C. Heterocyclic Studies. Part XXXXIX. Ring Cleavage of Some Pyrimidine Derivatives in Alkalai. J. Chem. Soc., Perkin Trans. 1 (1972-1999) 1976, 9, 1004-1007.

(32) Bruno, N. C.; Tudge, M. T.; Buchwald, S. L. Design and Preparation of New Palladium Precatalysts for C-C and C-N Cross-Coupling Reactions. Chem. Sci. 2013, 4, 916-920.

(33) Callahan, J. F., Li, Tindy, Wan, Zehong, Yan, H. Preparation of pyrazolo[3,4-b] pyridine Dual Pharmacophores as PDE4-muscarinic Antagonists. WO2009100169, 2009. 
(34) Bäckström, E.; Boger, E.; Lundqvist, A.; Hammarlund-Udenaes, M.; Fridén, M. Lung Retention by Lysosomal Trapping of Inhaled Drugs Can Be Predicted In Vitro With Lung Slices. J. Pharm. Sci. 2016, 105, 3432-3439.

Table of Contents Graphic

\begin{tabular}{r|c|c|c|c|}
\hline & \multicolumn{3}{|c|}{} \\
\hline $\mathrm{PI} 3 \mathrm{~K} \delta$ enzyme $\mathrm{pIC}_{50}$ & 9.4 & 9.3 & 9.3 & 9.2 \\
\hline $\mathrm{PI} 3 \mathrm{~K} \delta$ cell $\mathrm{pIC}_{50}$ & 9.1 & 8.8 & 8.0 & 9.9 \\
\hline Lung t⿳⺈(2) & $<0.1$ & 2.3 & 23.2 & 9.9 \\
\hline
\end{tabular}



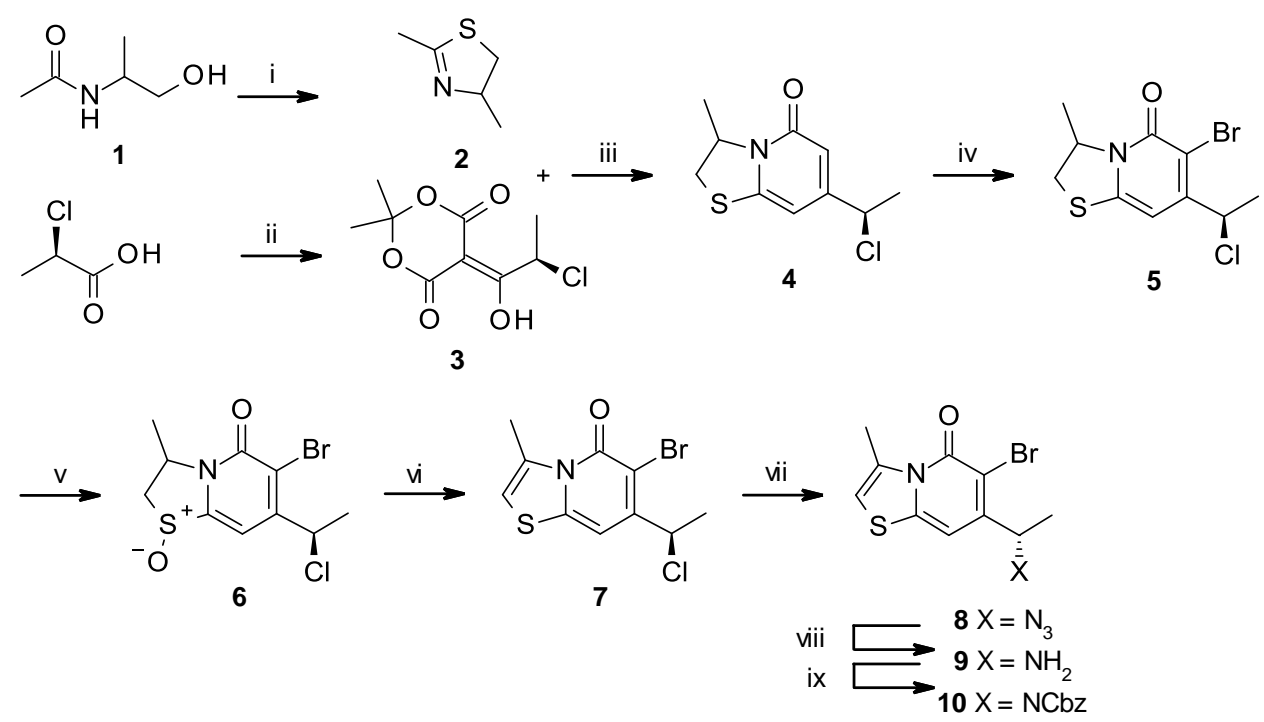
<smiles>[X]c1c(C(C)NC(=O)OCc2ccccc2)cc2scc(C)n2c1=O</smiles> 


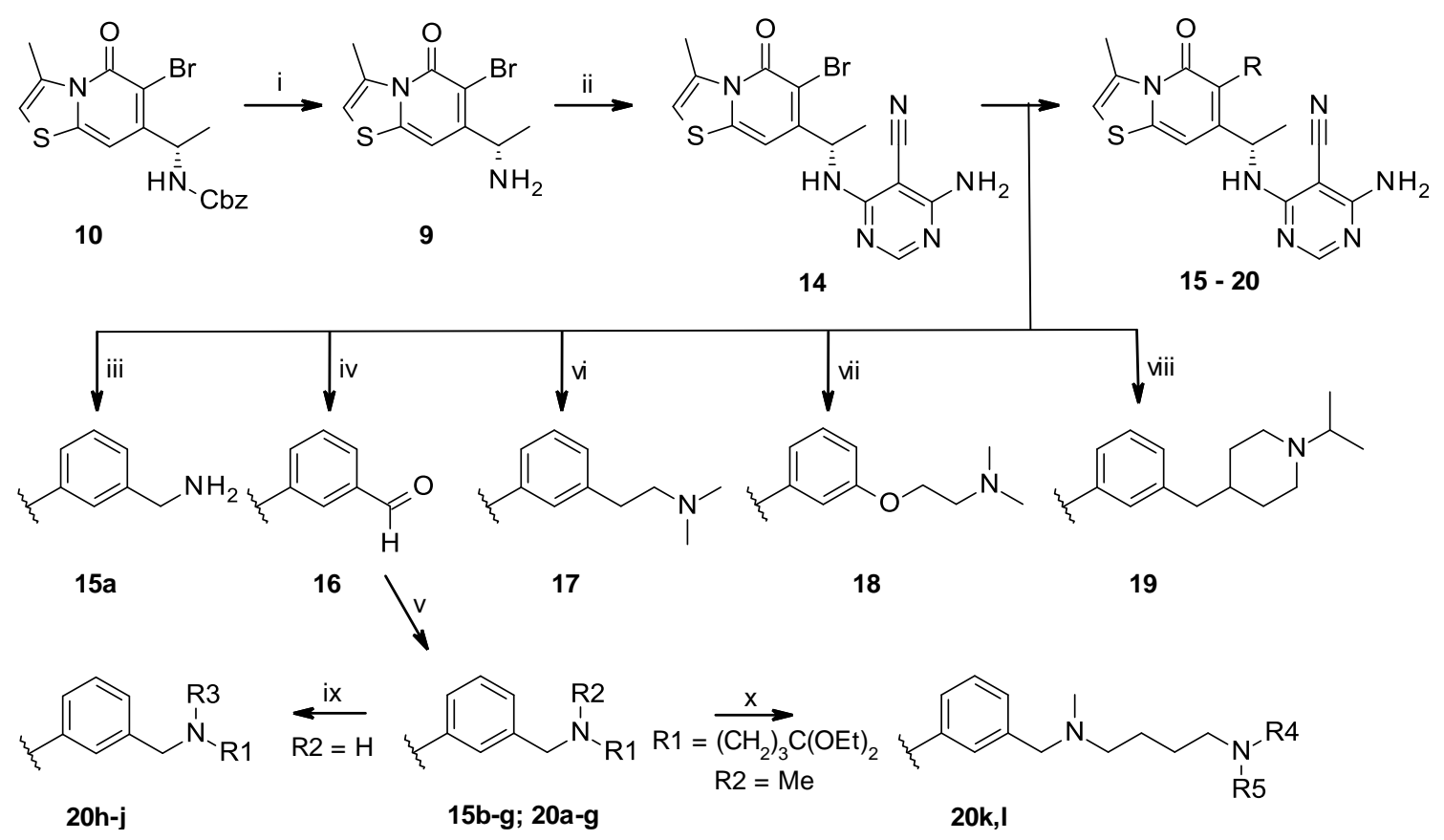


13, 15a-g 
*N 
15c, 17-19 
20a-I 
<smiles>CC(C)NCCN1CCOCC1</smiles><smiles>CN(C)C1CCN(CC(=O)O)CC1</smiles><smiles>CC(C)CN(C)CC1CCN(CC(C)(O)O)CC1</smiles><smiles>CC(C)N1CCN(CCN2CCOCC2)CC1</smiles><smiles>CN(CCC(F)(F)F)C1CCN(CC(=O)O)CC1</smiles><smiles>CC(C)CN(C)C1CCN(C(C)C(=O)O)CC1</smiles><smiles>CN(Cc1ccccn1)CC1CCN(CC(=O)[OH2+])CC1</smiles>

20h<smiles>CCN(CC)CCN1CCOCC1</smiles>

$20 i$<smiles>CN(C)CCCN(C)Cc1ccc(Cl)cc1</smiles>

20j<smiles>CC1CN(CCCN(C)C)CC(C)O1</smiles>

20k<smiles>CC1CN(CCCCN(C)C(C)C)CC(C)O1</smiles>

201<smiles>CN(C)CCCCN(C)Cc1ccccc1</smiles> 
<smiles>CC[C@H](Nc1ncnc2[nH]cnc12)c1nc2cccc(F)c2c(=O)n1-c1ccccc1</smiles>

A

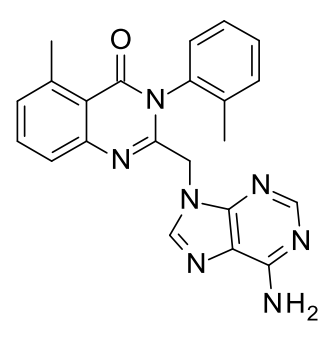

B 
Compound 13 bound in murine PI3Kd showing the ATP binding pocket with the induced pocket between Trp760 and Met752 and with hydrogen bonds to the NH of Val828 and the carbonyl of Glu826 making the hinge interaction.

$84 \times 69 \mathrm{~mm}(93 \times 94 \mathrm{DPI})$ 


\section{Page 63 of 69}

View of 15c (grey) overlayed with $\mathbf{1 3}$ (blue) showing the very similar conformations adopted by the ligands and the almost identical protein conformations. Note the movement of the sidechain amide of Asn836 permitting the dimethylamino group to be accommodated.

$84 \times 59 \mathrm{~mm}(100 \times 100$ DPI $)$ 
Docked structure of $20 f$ (grey) overlaid with $\mathbf{1 3}$ (blue) in murine PI3K showing the large substituted aminopiperidine accommodated in the solvent channel.

\section{$83 \times 61 \mathrm{~mm}(93 \times 94$ DPI $)$}


1

2

3

4

5

6

7

8

9

10

11

12

13

14

15

16

17

18

19

20

21

22

23

24

25

26

27

28

29

30

31

32

33

34

35

36

37

38

39

40

41

42

43

44

45

46

47

48

49

50

51

52

53

54

55

56

57

58

59

60

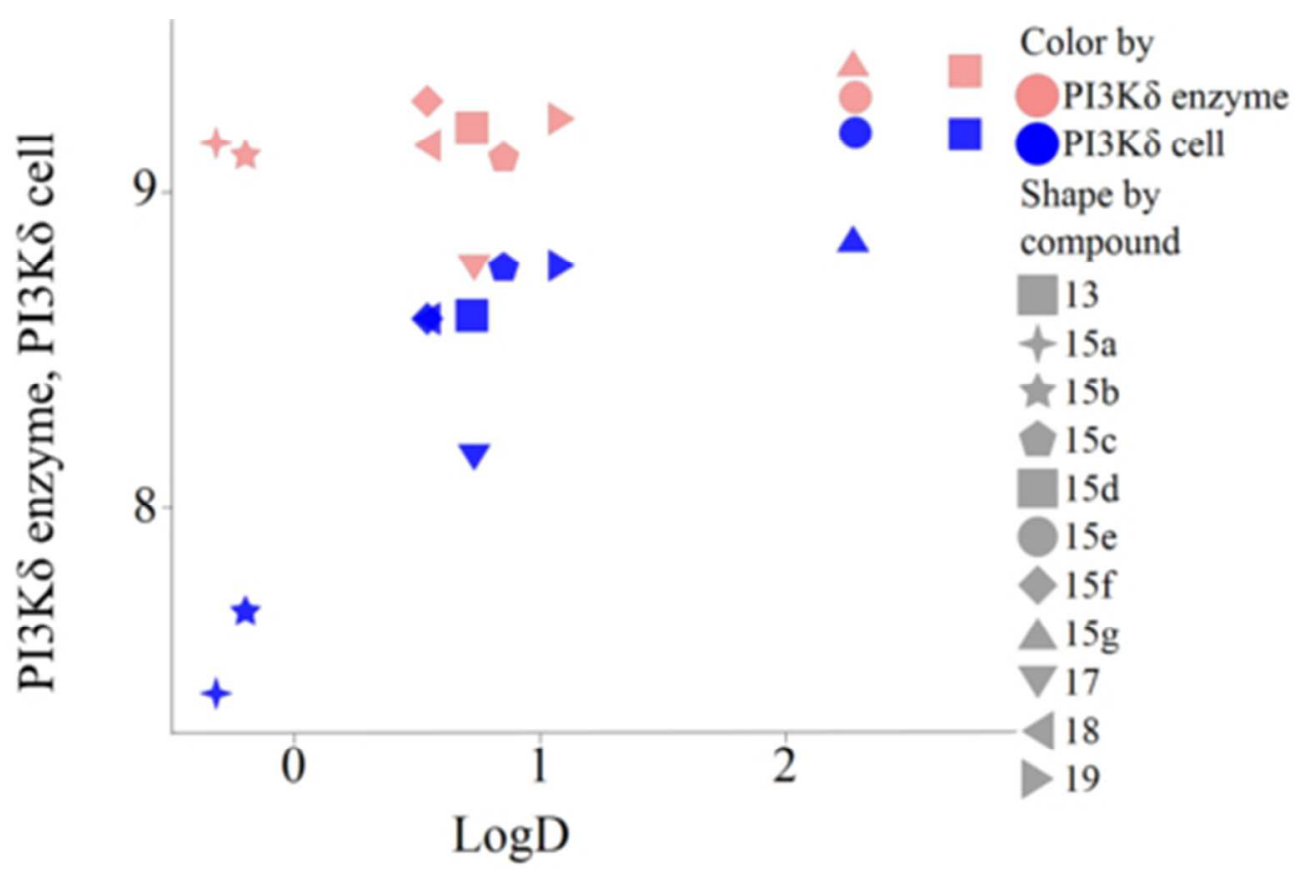

Enzyme and cell potencies for compounds 13, 15a-g, 17, 18, 19 showing cell drop-off at low lipophilicity. $84 \times 55 \mathrm{~mm}(150 \times 150 \mathrm{DPI})$ 


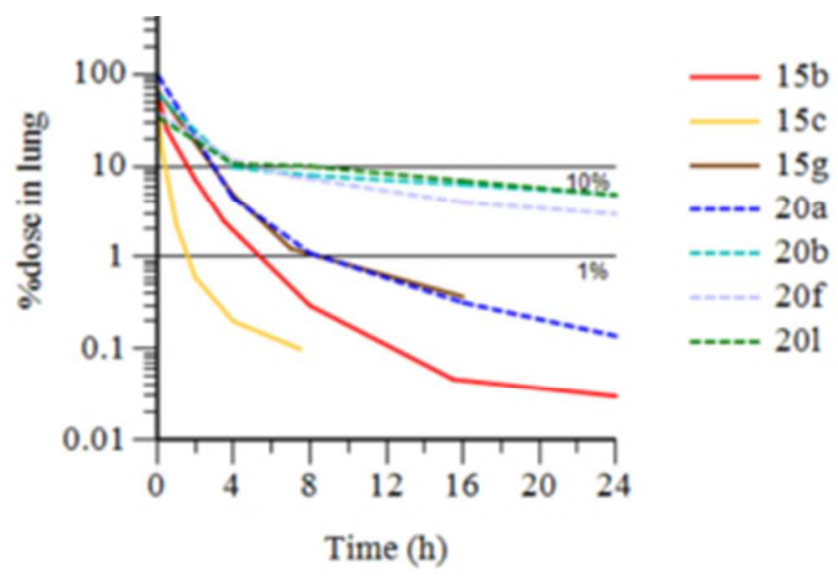

Rat ITPK time-course profiles of selected examples.

$84 \times 56 \mathrm{~mm}(96 \times 96 \mathrm{DPI})$ 

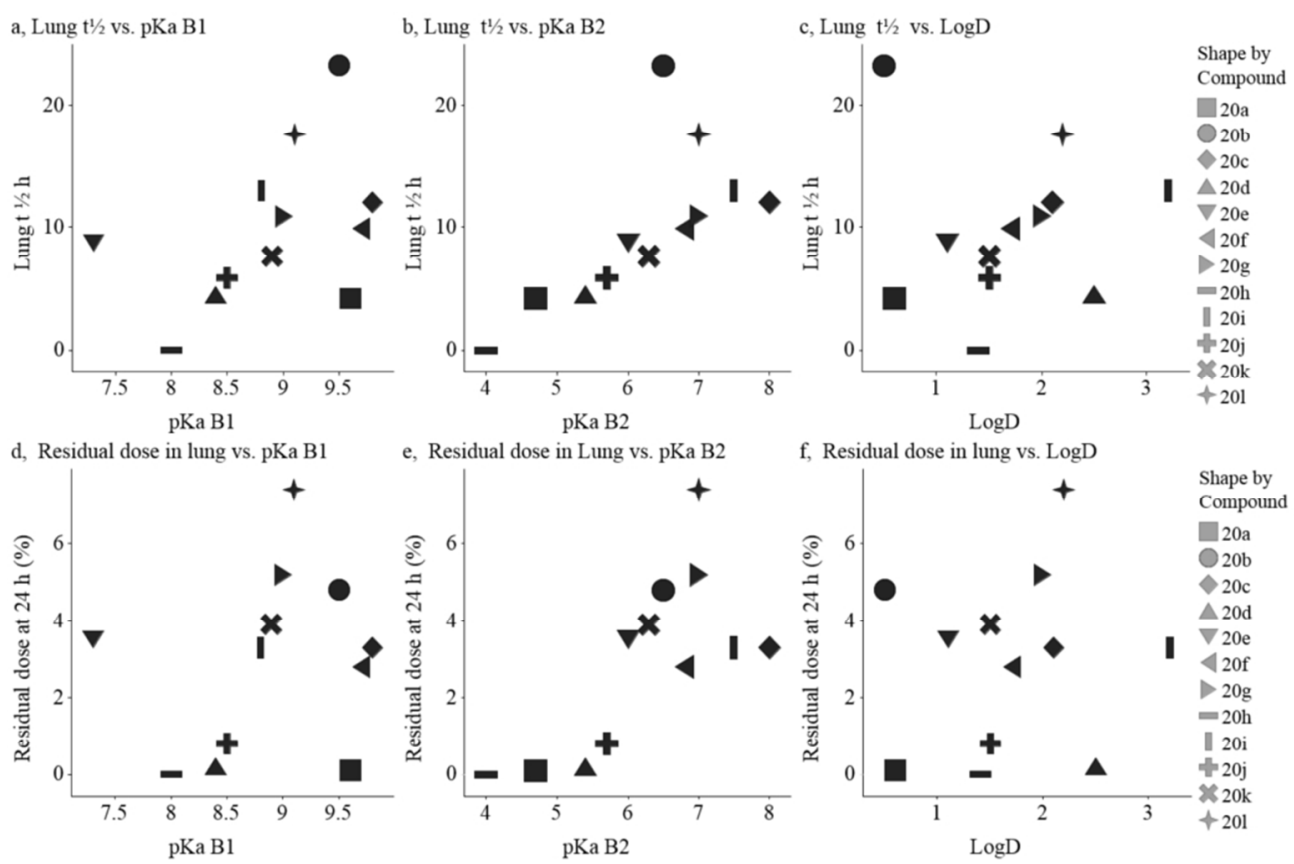

f, Residual dose in lung vs. $\log D$

Relationships between lung retention (\% remaining at $24 \mathrm{~h}$; half-life) and the first and second pKas or Lipophilicity (LogD) for dibases 20a-I.

$177 \times 115 \mathrm{~mm}(150 \times 150 \mathrm{DPI})$ 


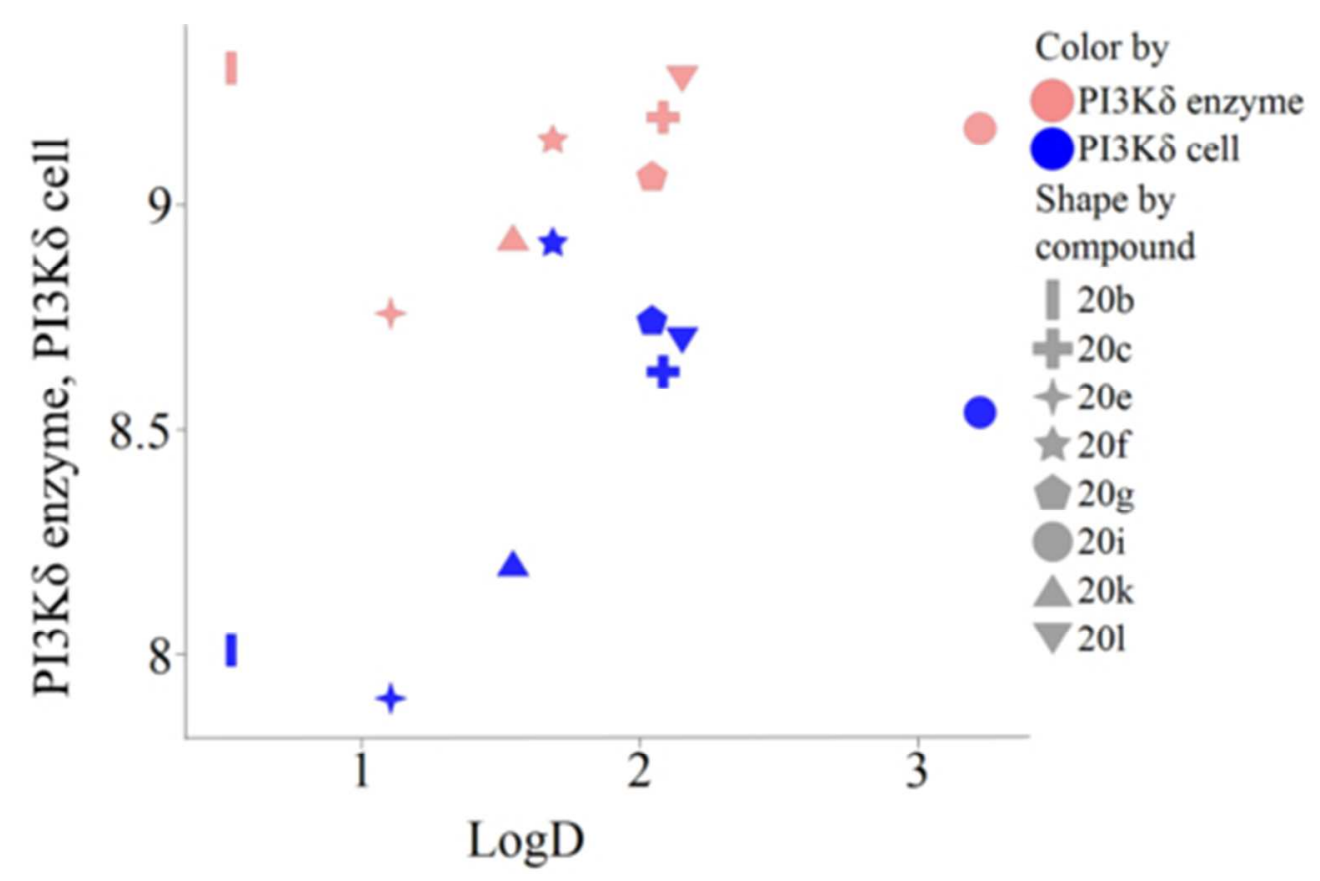

Cell drop-off for dibases.

$84 \times 55 \mathrm{~mm}(150 \times 150 \mathrm{DPI})$ 


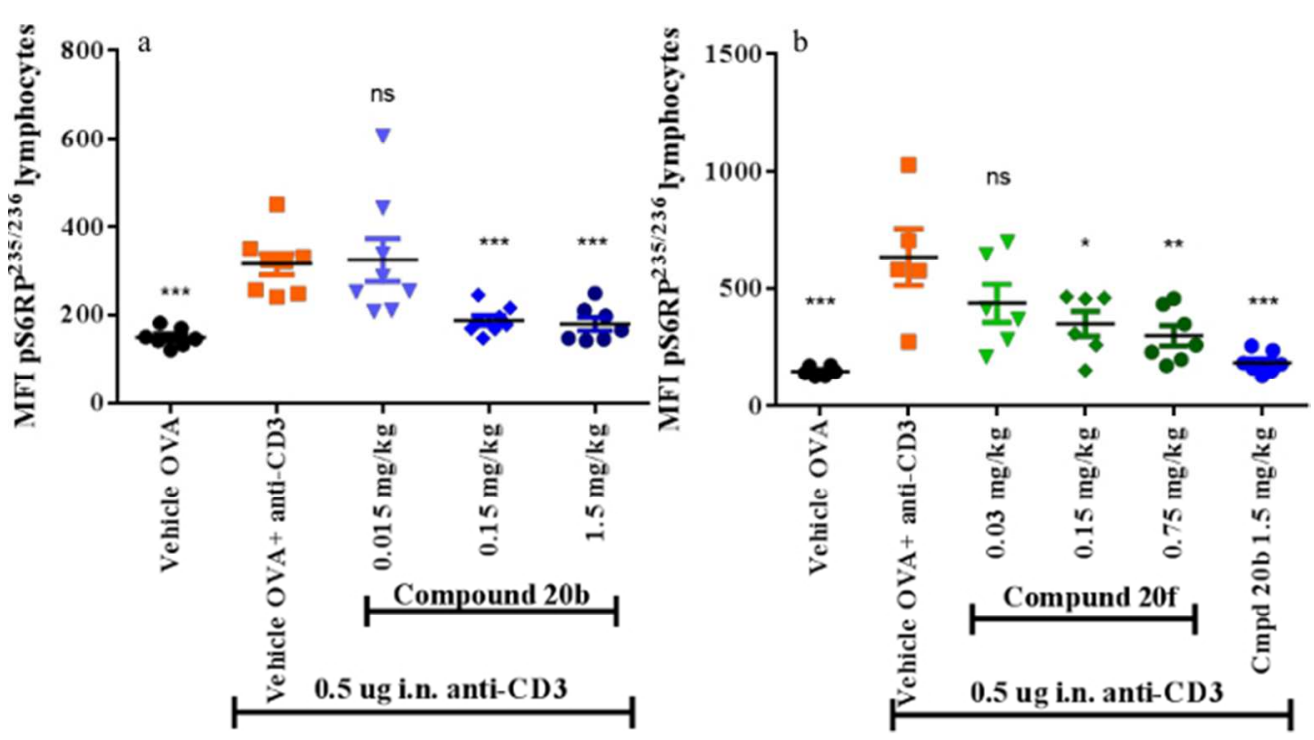

Inhibition of pS6RP in lung lavage after anti-CD3 challenge to OTII mice. 9a compound $\mathbf{2 0 b} \mathbf{9} \mathbf{9}$ compound 20f. Target engagement of PI3Kס activity is shown through measurements of pS6RP in bronchoalveolar lung lavage cells after anti-CD3 challenge to OVA-challenged OTII mice. Phosphorylation of S6RP, measured using phosphospecific antibodies, was significantly inhibited by both 20b (9a) and 20f (9b) in a dosedependent manner, however the inhibition by 20b showed better potency. Data is shown as results for individual animals at each dose with the statistical significance indicated as follows above the columns : $\mathrm{p}<0,001 * * * ; \mathrm{p}<0,005 * * ; \mathrm{p}<0,05 *$

$177 \times 96 \mathrm{~mm}(100 \times 100 \mathrm{DPI})$ 


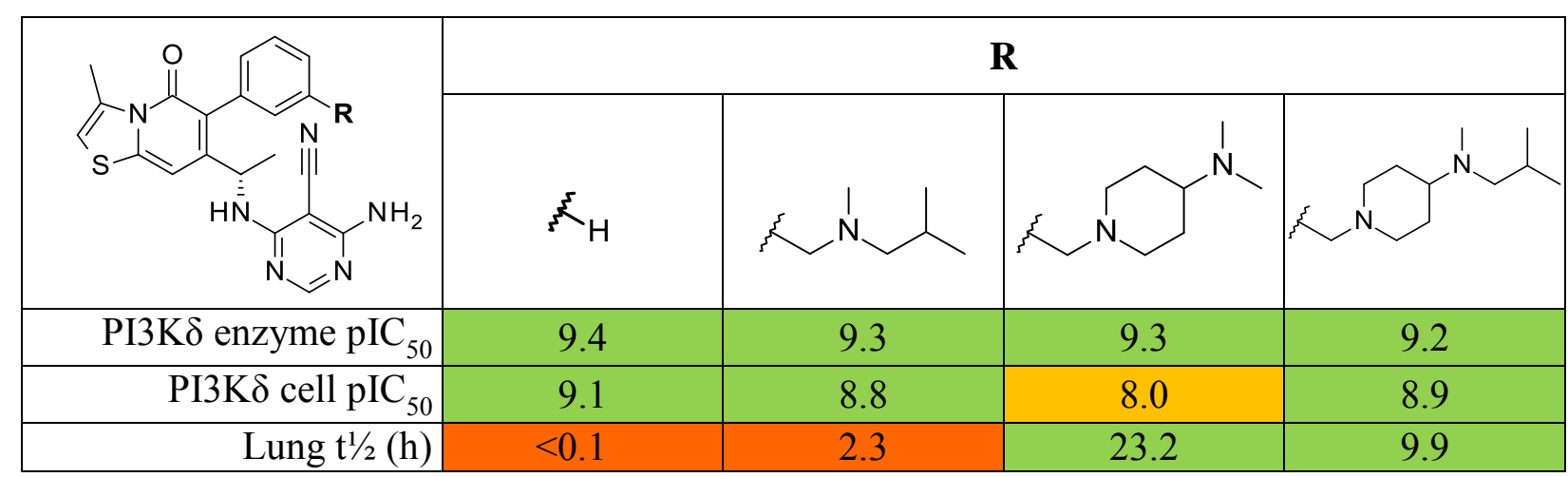

